University of Louisville

ThinkIR: The University of Louisville's Institutional Repository

Electronic Theses and Dissertations

$5-2013$

\title{
A progressive mind : Louis D. Brandeis and the origins of free speech.
}

Elizabeth Diane Todd

University of Louisville

Follow this and additional works at: https://ir.library.louisville.edu/etd

Part of the First Amendment Commons, Political History Commons, and the United States History Commons

\section{Recommended Citation}

Todd, Elizabeth Diane, "A progressive mind : Louis D. Brandeis and the origins of free speech." (2013). Electronic Theses and Dissertations. Paper 1446.

https://doi.org/10.18297/etd/1446

This Master's Thesis is brought to you for free and open access by ThinkIR: The University of Louisville's Institutional Repository. It has been accepted for inclusion in Electronic Theses and Dissertations by an authorized administrator of ThinkIR: The University of Louisville's Institutional Repository. This title appears here courtesy of the author, who has retained all other copyrights. For more information, please contact thinkir@louisville.edu. 


\title{
A PROGRESSIVE MIND: LOUIS D. BRANDEIS AND THE ORIGINS OF FREE SPEECH
}

\section{By}

\author{
Elizabeth Diane Todd
}

B.A., Transylvania University, 2010

\author{
A Thesis \\ Submitted to the Faculty of the \\ College of Arts and Sciences of the University of Louisville \\ in Partial Fulfillment of the Requirements \\ for the Degree of
}

Master of Arts

Department of History

University of Louisville

Louisville, Kentucky

May 2013 
Copyright 2013 by Elizabeth Diane Todd

All rights reserved 


\section{A PROGRESSIVE MIND: LOUIS D. BRANDEIS AND THE ORIGINS OF FREE}

SPEECH

By

Elizabeth Diane Todd

B.A., Transylvania University, 2010

A Thesis Approved on

April 9, 2013

by the following Thesis Committee:

Thomas C. Mackey, Thesis Director

Benjamin Harrison

Jasmine Farrier 


\section{DEDICATION}

This dissertation is dedicated to my parents

Robert and Martha Todd

for believing in me. 


\section{ACKNOWLEDGMENTS}

I would like to thank the History Department at the University of Louisville for providing me with the knowledge and support necessary for obtaining my degree. In particular, I want to thank Dr. Thomas Mackey for his guidance and encouragement over the past two years. He challenged me to work harder and inspired me to dream bigger. I want to thank my other committee members, Dr. Benjamin Harrison and Dr. Jasmine Farrier, for their assistance in my thesis work. I want to thank Lee Keeling for her tireless efforts to help graduate students like myself. I want to thank my fellow graduate students, Sarah Reddick and Erin Wotring, for helping me maintain my sanity. I want to thank the James Madison Memorial Fellowship Foundation for funding my graduate work and allowing me the opportunity to study at Georgetown University in the summer of 2012. I want to thank my family and friends for nurturing me and cheering me on. And finally, I want to thank Chad Byron for loving his little historian. 


\section{ABSTRACT \\ A PROGRESSIVE MIND: LOUIS D. BRANDEIS AND THE ORIGINS OF FREE SPEECH

\author{
Elizabeth Diane Todd
}

May 11, 2013

This study argues that Associate Supreme Court Justice Louis D. Brandeis played a key role in shaping the jurisprudence of free political speech in the United States. Brandeis's judicial opinions on three freedom of speech cases in the post-World War I era provide the evidence for this argument. This thesis demonstrates how the Espionage and Sedition Acts of World War I allowed Brandeis the opportunity to reflect and rule on the Founding Fathers' meaning of free speech in a political democracy.

Chapter I offers a detailed historiography of the Progressive Era and World War I. Chapter II provides a biography of Louis D. Brandeis and a historiography of civil liberties during World War I. Chapter III analyzes Associate Justices Holmes and Brandeis's shifting opinions on free speech in the 1919 cases of Schenck v. United States and Abrams v. United States. Chapter IV breaks down Brandeis's dissenting opinion in Gilbert v. Minnesota (1920). Chapter V examines Brandeis's solidified stance on free speech in the case of Whitney v. California (1927). In conclusion, this study finds that Brandeis's opinions created the language and support to apply the federal First Amendment to the states and to apply the "imminent threat" standard to free political speech cases. 
TABLE OF CONTENTS

PAGE

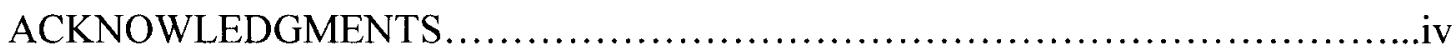

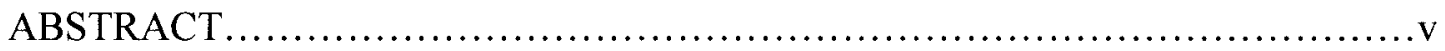

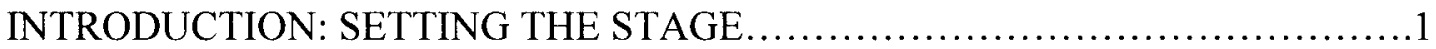

CHAPTER I: THE COMPLEX BACKDROP OF THE PROGRESSIVE ERA AND

WORLD WAR I............................................................

CHAPTER II: THE LIFE OF LOUIS D. BRANDEIS AND THE HISTORICAL

CONTEXT OF CIVIL LIBERTIES........................................... 30

CHAPTER III: THINKING THROUGH RATHER THAN AT THE FREEDOM OF

SPEECH: BRANDEIS'S ROLE IN ABRAMS V. UNITED STATES...................56

CHAPTER IV: WRITING HIS OWN OPINION: BRANDEIS'S MINORITY

DECISION IN GILBERT V. MINNESOTA .......................................80

CHAPTER V: CONCURRING, YET STANDING APART: BRANDEIS'S OPINION

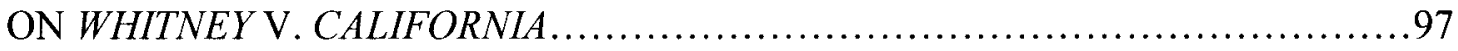

CONCLUSION: BRANDEIS'S LEGACY ON FREE SPEECH.....................121

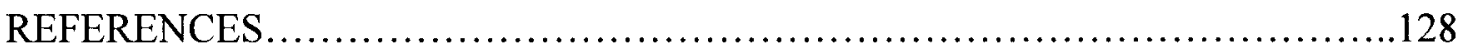

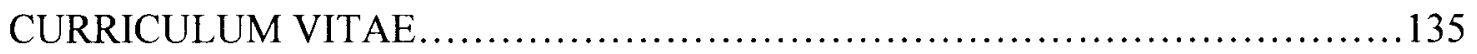




\section{INTRODUCTION}

\section{SETTING THE STAGE}

In the twenty-first century, scholars consider the First Amendment to define the fundamental rights of American citizens. Americans use their political freedom of speech on a daily basis through public protest, speeches, and strikes, and the distribution of their beliefs via papers and/or internet media. Yet, Americans have not always defended the freedom of speech of the First Amendment in such a manner. In 1791, the states ratified the Bill of Rights and constituted that "the people" was not nearly as expansive as it is today. Furthermore, the federal Bill of Rights only applied to the federal United States Constitution, leaving individual rights to be controlled by the state constitutions and their separate local customs and traditions. It would not be until 1925 , in Gitlow v. New York, that the concept of incorporation applied the freedom of speech in the federal Bill of Rights against the states. ${ }^{\prime}$ And even then it was a gradual process in which separate decisions by the United States Supreme Court applied each right from the Bill of Rights to the states under the "due process" clause of the Fourteenth Amendment, in a process known as "selective incorporation." 2 Rights have evolved over the past century to encompass all American citizens in all states. This thesis argues that Associate Justice Louis Brandeis of the United States Supreme Court played a significant role in shaping the eventual jurisprudence of the freedom of speech in the United States through

\footnotetext{
${ }^{1}$ Gitlow v. New York, 268 U.S. 652 (1925).

${ }^{2}$ Paul L. Murphy, Liberty and Justice: A Historical Record of American Constitutional Development (New York: Alfred A. Knopf, 1958), 302-303.
} 
his judicial opinions in the post-World War I cases, Abrams et al. v. United States (1919), Gilbert v. State of Minnesota (1920), and Whitney v. California (1927). ${ }^{3}$

Starting in 1914 with the outbreak of war in Europe, President Woodrow Wilson began his preparatory work for a united American front in case the United States entered the war. Traveling the nation, President Wilson gave numerous speeches that warned of aliens and hyphenates in the United States. Wilson referred to aliens as any non-United States citizens living in the United States and he identified hyphenates as any American citizens who were identified by their country of origin, for example German-Americans. He argued that if the United States entered the war, these individuals would side with their countries of origin and cause an internal security threat to the United States. He directed his conspiracy theory at German-Americans, Socialists, Irish-Americans and other groups that he deemed to be "radicals." In one speech to the Daughters of the American Revolution in 1915 he exclaimed, "I am in a hurry to have a line-up, and let the men who are thinking first of other countries stand on one side, and all those that are for America first, last and all the time, on the other side."

In 1916, President Wilson proposed legislation to Congress restricting freedom of speech and press. While not enacted then, the bill rested in Congress until 1917 when the United States entered the war. At that point, Wilson's threat of internal dissent was so ingrained in the minds of Americans that Congress passed the Espionage Act of 1917

${ }^{3}$ Abrams et al. v. United States, 250 U.S. 616 (1919); Gilbert v. State of Minnesota, 254 U.S. 325 (1920); Whitney v. California, 274 U.S. 357 (1927).

${ }^{4}$ Ibid., 53. See also, John Milton Cooper, Woodrow Wilson: A Biography (New York: Alfred A. Knopf, 2009).

${ }^{5}$ Ray Stannard Baker and William E. Dodd, The New Democracy: Presidential Messages, Addresses, and Other Papers (New York: Harper, 1962), 3:377. 
with broad public support. As historian Paul Murphy explained in World War I and the Origin of Civil Liberties in the United States:

Wilson's pre-entry attitudes and behavior were carried to their logical extreme when war came. The president was a man who could tolerate little criticism of himself or his policies at any time. Anticipating the necessity for coercing total national unity if a national emergency occurred, he began eliminating criticism by screening out people whom he was convinced the majority of Americans would feel had no business expressing strong, controversial views on the proper course for the nation. ${ }^{6}$

The preparatory work of Wilson's administration created what they hoped to be 100 percent American support and effort for the war. Indeed, the majority of the American public supported Wilson's effort for the war, yet, loyal Americans, who were ostracized by Wilson's discriminatory standards, strongly disapproved of Wilson's plan, including many German-Americans.

In April 1917 the United States entered World War I. However, by that time, the Great War in Europe was in full swing. It started in August 1914 with the assassination of Archduke Ferdinand of Austria. Due to a complex alliance system that had formed across Europe, the assassination sparked a war between the Triple Alliance, which consisted of Austria-Hungary, Italy, and Germany and the Triple Entente, which consisted of France, the United Kingdom, and Russia. European leaders had established these political and military alliances at the end of the nineteenth century and early twentieth century and these alliances constituted a delicate balance of power in Europe. The United States called for a non-intervention policy to begin the war because President Wilson and Congress wanted to maintain neutrality. In fact, President Wilson threw his support behind pacifist groups in the pre-war period in order to gain support for his non-

\footnotetext{
${ }^{6}$ Murphy, World War I, 55.
} 
intervention policy. Later pacifist groups felt betrayed by Wilson's entrance into the war and subsequent accusation of pacifists as a domestic threat.

In January 1917, American intelligence discovered a telegram that had been sent to the Mexican authorities. The American decoders determined the author of the telegraph to be the German Foreign Minister, Arthur Zimmermann. Many contemporary scholars believe that the telegraph was sent by the British in order to entice the Americans to join the Triple Entente. Regardless, the telegram made the claim that the German forces were going to evoke submarine warfare on United States submarines. In response to the telegram and the sinking of seven United States submarine ships, President Wilson and Congress declared war on Germany on April 6, 1917.

The number of battlefronts in Europe and the usage of trench warfare required thousands of United States soldiers to be sent overseas. In turn, the demand for soldiers affected many aspects on the home front in the United States. World War I became a total war for the United States, in which the federal government called on all citizens to help in the war effort. Regardless of age, gender, and race, the United States invoked all American citizens to assist in the feeding, clothing, and arming of the troops. Further, the high death rates of the war led to the United States government enacting a conscription measure in which young men were required to fight in the war if drafted. Some Americans disagreed with these wartime policies. To deal with these nonconformists in a swift manner, the federal government enacted the Espionage Act of 1917. According to legal historian Kermit Hall, the Espionage Act included two key censorship provisions:

First, the act made it a felony to attempt to cause insubordination in the armed forces, to interfere with the operation of the draft, and to convey false statements

${ }^{7}$ Ibid., 51-56. 
about the military with the intent of disrupting their operations. Second, the act permitted the postmaster to ban treasonable or seditious material from the mail. ${ }^{8}$ President Wilson had proposed this Act in 1916 and with the outbreak of war in 1917, Congress enacted it. Wilson's administration felt that the Espionage Act would curb dissent on the home front and allow the government to focus on the war abroad. However, the disgruntled pacifists and other radical leaders continued to speak out in disapproval of the United States foreign politics. Therefore, in 1918, Congress passed an amendment to the Espionage Act called the Sedition Act, which made it a felony to "disrupt or discourage recruiting or enlistment service, or utter, print, or publish disloyal, profane, scurrilous, or abusive language about the form of government." ${ }^{9}$ In doing so, the government gave power to the Attorney General to arrest radicals who spoke out against the government. Again, most public opinion supported this measure because Americans feared an internal security threat.

In addition, in 1917, President Wilson created the Committee on Public Information, headed by George Creel, to enforce the wartime policies through a propaganda campaign. The campaign called on Americans to support the war effort and identify those citizens who opposed or spoke out against American involvement in World War I. The main job of the committee was censorship. Wilson wanted his war policies propagandized to the American people. He distrusted reporters and thus, put his own people in charge of news dissemination..$^{10}$

\footnotetext{
${ }^{8}$ Hall, The Magic Mirror, 271; Espionage Act of 1917, Public Law 65-24, U.S. Statutes at Large 217 (1917).

${ }^{9}$ Sedition Act of 1918, Public Law 65-150, U.S. Statutes at Large 553 (1918).

${ }^{10}$ Murphy, World War I, 75; See aiso Stephen Vaughn, Holding Fast the Inner Lines: Democracy, Nationalism, and the Committee on Public Information (Chapel Hill: University of North Carolina Press, 1980).
} 
World War I and President Wilson's wartime policies shaped the setting for the political freedom of speech cases in this study. While not all three cases developed directly from wartime events, it was during the American involvement in World War I that a narrow national consciousness of civil liberties began to foment. Louis D. Brandeis was among the limited group of people who began to see problems with the interpretation of free political speech in the First Amendment. However, before jumping into Brandeis's role in shaping the eventual jurisprudence of the freedom of speech, one must understand the historical context of America at the turn of the twentieth century in order to fully appreciate all of the changes taking place in society, politics, and the legal realm. 


\section{CHAPTER I}

\section{THE COMPLEX BACKDROP OF THE PROGRESSIVE ERA AND WORLD WAR I}

The turn of the twentieth century is a difficult period to understand in United States history because of the complex nature of the nation transitioning into modernity. From the post-Reconstruction age through World War I, Americans experienced changes in all realms of life, including society, politics, and economics. The United States went from having a decentralized government, agriculture-based economy, rural living communities, and a divided class system to having a strong federal government, industrial-based economy, large urban communities, and a newly formed middle-class. The rapid development of America from the 1890 s to the early 1920 s explains why historians often refer to the period as the Progressive Era. Although it should be noted that "progressive" is a complex and ambiguous term. During World War I, Europeans and other foreign peoples began to view the United States as an international power. In addition, Americans started to develop a sense of nationalism and a distaste for unAmerican behavior. Understanding this time period in American history is essential to understanding contemporary America.

However, as with any time of great change, conflict and disagreement exist. In the same way, historians encounter conflict and disagreement on how the period should be studied and interpreted. This chapter presents the different historical approaches of historians writing from the second half of the twentieth century to the present. The publication parameters of this segment have been selected to consolidate the field of 
writing and offer more recent arguments. This historiography is far from complete, but endeavors to incorporate many of the classic works in the field, while also addressing the recent literature. The important concept to take away from this historical context is that the Progressive and World War I era was complicated, so much so that historians are still grappling with the conceptual issues even today. Similarly, the Supreme Court cases on the freedom of speech in the post World War I years proved complicated as well in the wake of this age of reform. This chapter establishes the historical setting for the three Supreme Court cases in this study. Furthermore, it provides the American backdrop for Louis D. Brandeis's life and career on the Supreme Court.

\section{The Historiography of the Progressive Era and World War I}

Richard Hofstadter was an American historian who taught at Columbia University and received the Pulitzer Prize twice for his publications. Published in 1955, The Age of Reform, was one of his classic works that received such an honor. Though he died in 1970 , his work on the late nineteenth and early twentieth century continues to influence the way that scholars understand the period. Hofstadter argued that the Populists of the 1890s and the Progressives of the early 1900s held up such unobtainable ideological standards that it was impossible for them to be successful. ${ }^{1}$ The Populists idealized the "agrarian myth," which emphasized an economic return to the hardworking and moral yeoman farmer, instead of the commercialized business industry. The Progressives idealized the "industrial myth," which emphasized a community without immigrants or big businesses where government enforced middle class authority. Hofstadter contended

\footnotetext{
${ }^{1}$ Richard, Hofstadter, The Age of Reform (New York: Vintage Books, 1955).
} 
that the fear of losing social status drove the reform movements of the farmers of the Populist Party and the middle-class citizens of the Progressive Party. These ideologies formed the basis of Hofstadter's book, which offered a new approach to understanding the widely studied "age of reform."

Hofstadter's book covered the years from 1890 to 1940 and he divided his examination into sections on the Populists, the Progressives, and the New Deal, with an emphasis on the first two eras. His examination of the Populist Party described the agrarian myth fully, emphasizing the party's desire to turn away from urbanization and return to the agricultural community that the Founding Fathers and Thomas Jefferson established at the start of the new nation. The Populists called for a restoration of the pastoral past. They found support from farmers and small businessmen who suffered under the railroad and bank chiefs. However, Hofstadter explained how this call for reform was impossible to obtain due to the fact that big businesses, improvement in farming techniques, and the commercialization of farming were irreversible shifts necessary to feeding the masses and maintaining efficiency. Even the yeoman farmers who were idealized did not reap the economic benefits of small farming and often found commercial farming to be their best option. Urbanizing America forced farmers to shift from local farming to regional farming, and beyond.

Urban, middle-class citizens comprised the Progressive Party and they felt that immigrant workers on one side and political machines on the other side squeezed them out of the political process. Through muckraking journalism, the Progressives exposed corruption and lawbreaking by these two groups and called for a return of government to the people. However, two factors restrained the Progressives: disorganization and war. 
Besides the common call for government intervention, the Progressives differed on approach and structure, spreading their movement too thin. Furthermore, with the outbreak of war in Europe in 1914, the Progressives lost a lot of their liberal support for reform because wartime evoked a conservative stance out of the majority of the population. Therefore, for Hofstadter, the Progressives momentum dissipated in the war years and it did not pick back up in the post-war years.

Hofstadter offered an interesting new approach to studying the turn of the twentieth century; however, many flaws existed in his argument. To start, his description of the Populist Party as anti-Semitic does not take into account the historical context of the era. Anti-Semitism was a common perspective of people in the 1890s, and many of the Populists were not anti-Semitic. By lumping the beliefs of thousands into one strict description he lost sight of the disparities within the Populist Party. Secondly, Hofstadter's focus on the myths of Populist and Progressive parties as their ultimate breakdown, failed to consider the gravity of other factors, such as disorganization and war. Though he mentioned these factors, he did not regard them as major influences. Many historians argue that these two parties proved unsuccessful due to their third party status in United States politics, making them not powerful enough to fund or organize mass followings. Furthermore, wartime played a huge role, both in the SpanishAmerican War of 1898 and World War I, in putting a freeze on reform movements for the sake of unifying against the enemy. Hofstadter's argument needed a wider 
examination of the factors involved in the breakdown of the Populist and Progressive movements. ${ }^{2}$

In 1963, Arthur S. Link followed Hofstadter's political approach with his work, Woodrow Wilson and the Progressive Era, 1910-1917. While teaching at Northwestern and Princeton University, Link devoted his career to the study of Woodrow Wilson and the politics and diplomacy of the period from 1910-1920. Link wrote this work as part of the American Nation series, which is rewritten every fifty years or so to create a comprehensive American history for scholars and the general public. As the scholarly authority on Woodrow Wilson, the American Nation editors placed Link in charge of the period of Wilson's political life prior to World War I. In his book, Link argues that Wilson was less of a Progressive and idealist than people acknowledge him as for his work in his second term. ${ }^{3}$

Starting with the election of 1912 between Theodore Roosevelt, William Howard Taft, Eugene Debs and Woodrow Wilson, Link contends that Roosevelt's New Nationalism platform was the most progressive of the men running for presidential office. Link explains that Wilson's New Freedom platform called for much more moderate reforms. He argues that Wilson's economic reforms drew from Louis Brandeis's concepts of the "curse of big business." Once in office, Link described Wilson's first term reforms as weak. For example, while he worked to lower tariff laws, he supported

\footnotetext{
${ }^{2}$ For another look at the 1950 s political approach see Samuel P. Hays's Conservation and The Gospel of Efficiency: The Progressive Conservation Movement, 1890-1920 (Cambridge, Mass.: Harvard University Press, 1959) which assesses at the conservation movements at the turn of the twentieth century and the various groups, elites and grassroots individuals, who conflicted in their political approaches to environmental solutions.

${ }^{3}$ Arthur S. Link, Woodrow Wilson and the Progressive Era, 1910-1917 (New York: Harper \& Row Publishers, 1963).
} 
the passing of the Sixteenth Amendment, the income tax. Moreover, Wilson did not support child labor laws, women's suffrage or immigration. He also enforced segregation within the government and society. Even with the start of the European conflict in 1914, Link demonstrates how Wilson took the middle road, offering trade with both Germany and the Allies. Link presents Wilson as a stubborn man who did not intend for such social and political reforms. Ironically, however, in 1916, Wilson campaigned on the basis of keeping America out of the war and for continued progressivism. Also in 1916, he put Louis Brandeis, a Jew, on the Supreme Court and initiated talks for child labor laws. Link makes it clear that Wilson's first and second terms differed widely. In his first term, he was not the reformer that people remember him as today. Link claims that Wilson's unexpected foreign affairs issues forced him to become a reformer in his second term as President. ${ }^{4}$

While maintaining a partially political approach, Robert $\mathrm{H}$. Wiebe, former professor at Northwestern University, shifted the historiography of this period by introducing social history to the mix. His 1967 work, The Search for Order, 1877-1920, presents the idea of the "new middle class," which he argues developed in this time period and made up the group of people responsible for the progressive reforms that brought America into the modern era. ${ }^{5}$ Wiebe studied the shift in American values from

\footnotetext{
${ }^{4}$ In 1963, Gabriel Kolko published his work The Triumph of Conservatism: A Reinterpretation of American History, 1900-1916 (Chicago: The Free Press of Glencoe, 1963), in which he argued contrary to the belief that progressivism was a middle class reaction against big business and he also argued contrary to the belief that the federal government sought to destroy big business. He focuses on the political and economic realms of the period to draw conclusions.

${ }^{5}$ Robert H. Wiebe, The Search for Order 1877-1920 (New York: Hill and Wang, 1967).
} 
the small island communities to the growing urbanized nation. He claims that railroads connected the once isolated towns and shifted the economy to a more integrated one.

By expanding the economy and means of travel, more people sought training and education in professions. Wiebe identifies the middle class as the group of individuals that worked to obtain expertise in various professions for economic and social gains. For example, standardization in instruction for medicine, law and business occurred. In turn, Wiebe argues that this training instilled in the middle class a desire to reform the government into an organized, managerial, bureaucratic and efficient institution. The middle class called for public health initiatives, tax assessments, secret ballots, an end to corruption by bosses, railroad regulation and many other reforms in the early $1900 \mathrm{~s}$, especially in regard to government control.

Wiebe is one of the first historians to try and understand American values at the turn of the century. However, his view of the progressives is too narrow. He limits the progressive reforms to the middle class, claiming that they alone elicited change. While much of the reform movement may have come from the professional middle class, one economic class cannot define the progressives. Social and cultural elites, such as the Vanderbilts and Roosevelts, had a role in the progressive movement, as did working class laborers. Nonetheless, Wiebe's work is a classic because of his analysis of the shift from the island communities to the urban communities. Wiebe goes beyond the political to the social realm, giving readers greater insight into the societal changes and problems of the time.

Over a decade later in 1980, David M. Kennedy dove deeper into the social sphere with his work, Over Here: The First World War and American Society. As a 
professor at Stanford University, Kennedy utilized economics, culture, society and politics to analyze the history of early twentieth century America. In this particular book, he examines America's home front from April 2, 1917 to November 11, 1918. He argues that the way Americans mobilized, chose to fight, and then went about winning the war explains a great deal about the enduring American character. ${ }^{6}$ His work centers on America shifting from an isolationist nation to an international power. He contends that this transformation led to a more centralized American government and a more divided American populace.

Prior to World War I, Kennedy demonstrates how the Progressives, such as Theodore Roosevelt, balanced self-government and efficient government. Yet with war, people demanded greater federal government control and greater efficiency. However, not all Americans agreed on how governments should be run and in effect, many divisions erupt among varying social and political groups, including socialists and democrats. In addition, Kennedy argues that the war exposed the inefficiency and organization of the American economy. Once again, American people divided on how to handle the economic issues, such as raising money for the war effort. Beyond politics and economics, Americans argued over military strategy and civil liberties. In the end, Kennedy contends that the majority of Americans were disappointed with the results of the war.

Kennedy draws largely from Wiebe's concept of the breakdown of the island communities and the rising new world of internationalism. He provides a great deal of content on the American home front during World War I, demonstrating the societal

\footnotetext{
${ }^{6}$ David M. Kennedy, Over Here: The First World War and American Society (New York: Oxford University Press, 1980).
} 
conflicts that come with any war period. However, his argument that the majority of people were disappointed with the aftermath of war is overstated. In fact, it was intellectual minorities who were most disappointed, such as women's suffrage leaders and Woodrow Wilson. The majority of people were quite pleased with America's victory at war and economic prosperity from the war industries as is evidenced by the lack of unrest in the United States in the post-war months. Moreover, most Americans called for greater federal government regulation, especially of aliens and radicals, who posed a threat to the American nation. By the end of World War I, Americans had just started to develop notions of a civil liberties consciousness. Thus, Kennedy would do well to specify his argument to the intellectual minorities who did not support the growth of the federal government and the suppression of dissenters.

In 1981, a year after Kennedy's social analysis, T.J. Jackson Lears introduced an entirely new approach to studying the late nineteenth and early twentieth centuries: psychohistory. His work, No Place of Grace: Antimodernism and the Transformation of American Culture, 1880-1920, was an intellectual and cultural history that opened the historical field to new and interesting debates. As a professor at Rutgers University, Lears used sermons, diaries, letters, novels, poems and essays to argue that elites at the end of the nineteenth century sought antimodernism to regain their cultural authority in opposition to the growth of the middle class and progressive reform movement. ${ }^{7}$ Lears contends that elites were not simply nostalgic for previous wealth and power; in fact, they searched for a way to accommodate and find "realness" within modernization. Lears

\footnotetext{
${ }^{7}$ T.J. Jackson Lears, No Place of Grace: Antimodernism and the Transformation of American Culture, 1880-1920 (New York: Pantheon Books, 1981).
} 
explains that elites faced the problem of "weightlessness" and disassociation during this period of change.

Lears's approach is intellectualized drawing on the artistic concept of impressionism and psychological theory of child escapism to explain how elites dealt with industrial technology, bureaucratic organization, and systematic clockwork. He analyzes the pill-popping trend of elites during the period, in which they would take opium, cocaine or morphine for comfort and he also addresses the neurasthenia epidemic, in which wealthy citizens would develop nervous symptoms, such as the inability to speak or move. He explains that elites turned to an arts and craft ideology in an attempt to return to Wiebe's island communities with the idealization of manual labor and a return to the soil. Further, elites took vacations and therapies to escape the transitional period.

Lears presents a unique and fascinating window into the lives of elites at the turn of the twentieth century. However, his argument that the elites searched for something more "real" is strained. Doing drugs and having nervous breakdowns does not necessarily mean that all elites struggled to cope with modernity. Many may have been or were probably bored and/or addicted. As an elite himself and married to an artist, Jackson Lears incorporates too much personal entitlement into his argument. He fails to define antimodernism, which presents many problems to his argument and he tends to sympathize with the elites. Regardless, his work is a contribution to the historiography because it offers a psychological and intellectual approach to the largely political and social field of study. His work raises questions that may have gone unnoticed had it not been for his research efforts. 
In 1983, John Milton Cooper Jr., who teaches at the University of Wisconsin, returned to the political historical approach with elements of philosophy. His work, The Warrior and the Priest: Woodrow Wilson and Theodore Roosevelt, is a comparative biography of two early twentieth century American presidents: Woodrow Wilson and Theodore Roosevelt. The goal of his book is to demonstrate the effects that the two men had on each other and on the modernization of American politics. By tracing both of their lives from childhood to death, Cooper compares their backgrounds, characters, and political aims. $^{8}$

Cooper draws the underlying theme to this work from the nineteenth century, German philosopher Friedrich Nietzsche's concept of the warrior and the priest. According to his philosophical model, the warrior is a man of honor who goes beyond self-interest for the common good. Conversely, the priest is a devious man of weak character who seeks self-interests through cunning and conniving. Cooper assigns Wilson as the warrior and Roosevelt as the priest in his title. He then develops these ideas in his book depicting the lives of these men to explain why he so labeled them. Through an analysis of their domestic and foreign policies, Cooper argues that Wilson was a realist who had a clear agenda and an analytical and academic approach. On the other hand, Cooper argues that Roosevelt portrayed an image of rugged individualism, focusing more on his public dramatization and idealistic reforms than the every day needs of the American people.

${ }^{8}$ John Milton Cooper, Jr., The Warrior and the Priest: Woodrow Wilson and Theodore Roosevelt (Cambridge, Mass: The Belknap Press of Harvard University Press, 1983). 
Starting with their childhoods, Cooper found similarities in their family backgrounds. Both men came from comfortable means with a strong sense of patriarchy. Roosevelt was born into great wealth and materialism, though he suffered from asthma and digestive problems. Wilson was born into a Presbyterian ministerial family and suffered from dyslexia. Cooper contends that although both men faced personal limitations, they both overcame their limitations with determination. Roosevelt took up sports and military activism and Wilson practiced memorization techniques and became an avid reader and writer. They both attended prestigious universities where they pursued further education in American politics. However, it was Roosevelt's family name that allowed him to transition into the political world; whereas, Wilson had to take a detour through academics to earn his name in politics.

In 1902, Roosevelt became President of the United States with the death of President William McKinley. In the same year Wilson became President of Princeton University. Interestingly, Cooper explains that the men were acquainted and held a mutual respect for the other. They both achieved successes in their leadership roles; but, by 1908 , Roosevelt had renounced a second term and the Board of Trustees was pushing Wilson toward resignation for his radical reforms to the undergraduate curriculum and residence areas. Once again both men overcame these downturns in their careers and, by 1912, faced off in the presidential campaign.

With Taft winning the incumbent nomination from the Republican Party, Roosevelt started the Progressive Party, running on a theme of New Nationalism. He preached an idealistic vision of nationalism. but lacked a war for such patriotism. Spending his entire life overcompensating for the fact that his father did not serve in the 
Civil War, Roosevelt went out of his way to fight in the War of 1898 and presented an imperialistic and militaristic foreign and domestic policy. Wilson was the nominee of the Democratic Party and he ran on the theme of New Freedom, on which he presented the realistic vision of reform through the interests of the majority. Wilson renounced imperialism and took a nonintervention approach to foreign affairs. Though sharing similarities in their anti-machine and government intervention policies, the men attacked each other and played off the other's mistakes.

Once in office, Wilson instituted his domestic and foreign policies with the constant criticism of Roosevelt and his followers. Roosevelt continued to find his way into the public spotlight, including going to the White House and asking to lead a volunteer troop on the Western Front. Roosevelt was emotional and overbearing. Conversely, Wilson showed steadfastness in regards to the war and fought for nonintervention, but preparedness until 1917 when the foreign threat forced the United States to enter the war. Even so, Wilson fought on the grounds that winning the war would make the world more peaceful. Wilson maintained this perspective through the peace talks in Paris where he introduced his conception of the League of Nations.

Shortly after the war's end, both men died, leaving behind great and troubled legacies. As Cooper contends, "Theodore Roosevelt and Woodrow Wilson still stand as the principal architects of modern American politics." 9 Cooper's work is a classic in the historiography of early twentieth century politics. Understanding the backgrounds, characters, and policies of Roosevelt and Wilson explains the basis for modern American politics. Presenting Wilson as the clear-headed "warrior" and Roosevelt as the selfish

${ }^{9}$ Ibid., 361. 
"priest," Cooper takes a new and convincing approach to comprehending the lives of these two influential men.

Also following the return to the political methodology, in 1985 Robert Ferrell published Woodrow Wilson and World War I, 1917-1921. Ferrell received his Ph.D. from Yale University and taught at Indiana University Bloomington. In addition, he served in the Air Force in World War II and worked as an intelligence agent in the Korean War. His work is a clear product of his academic and military background. Written as a part of the New American Nation Series, Ferrell's book picks up the story of Woodrow Wilson in 1917 where historian Arthur Link left off with his 1963 work, Woodrow Wilson and the Progressive Era. Ferrell's historical focus is the use of presidential power, which can be seen in his various publications on Harry S. Truman, Calvin Coolidge, Woodrow Wilson, Warren G. Harding, and Dwight Eisenhower. For his research on Wilson during and after the Great War, he used the archives of four countries, manuscript collections, oral histories, unpublished reminiscences of some of the military participants in the war, diaries and letters of soldiers, and Woodrow Wilson's papers. From his study of these materials and the use of secondary sources, Ferrell concludes that Wilson succeeded in his decision to go to war and his leadership during the war, but he failed with his peace negotiations in the post-war years because of personal illness and his inability to delegate. ${ }^{10}$ Ferrell presents a clear picture of Wilson's administration during the war, though his nationalistic and militaristic opinions sometimes deflated his arguments and left room for criticism.

\footnotetext{
${ }^{10}$ Robert H. Ferrell, Woodrow Wilson and World War l, 1917-1921 (New York: Harper \& Row, Publishers, 1985).
} 
Aiming his book at an undergraduate and general audience, Ferrell follows chronological order with close attention to detail. He starts his narrative in April 1917 when President Wilson went to the Capitol to ask for war. Building from that point, Ferrell spends the next eight chapters on the militaristic, diplomatic, and political developments taking place during the war. Ferrell exposes his nationalistic perspective when he declares, "It is not too much to say that the creation of a great American fighting army, the American Expeditionary Forces, was the most decisive act by any nation in the war, the single act that determined the defeat of Imperial Germany in November 1918." Ferrell leaves no room for the variety of factors that also likely played a role in the defeat of Germany including the conflict of the Bolshevik Revolution in Russia and the internal collapse of the German state. He argues that Wilson was a Progressive at war, leading the nation to victory.

Nonetheless where Ferrell exaggerates on America's military prowess, he does an excellent job of identifying the issues of America fighting in its first large-scale, overseas war, naming logistics as the biggest problem. He breaks down Wilson's cabinet to see who was and who was not an "ignoramus" in the business of war. ${ }^{12}$ He praises Wilson for using a "no politics" stance when naming heads of various departments, once again describing Wilson as a Progressive in his appointing of competent experts to his cabinet. Although the United States Army, Navy and Air Force struggled to organize and obtain the proper amount of food and armaments, Wilson found intelligent leaders to tackle these problems, including General Peyton C. March as Chief of Staff and Herbert Hoover as food administrator.

\footnotetext{
${ }^{11}$ Ibid., 15.

12 Ibid., 117.
} 
In the last portion of his book, Ferrell connects Wilson's failure in the post-war period to his recurrent illnesses and stubbornness. In his poor health condition, Ferrell criticizes Wilson for going to Paris for the peace talks and traveling throughout the United States to campaign for the League of Nations. Ferrell identifies hubris as the reason behind Wilson's need to do everything himself. Ferrell also links this lack of delegation to Wilson's stroke in 1919 that "turned him into a shell of a man, incompetent to occupy the office of President." ${ }^{13}$ Ferrell supports this argument by examining how Wilson had to be shut away from the media to recover and how his wife took over his presidential duties. Then, Ferrell makes a bold statement claiming, "He [Wilson] should have resigned immediately in favor of Vice President Thomas R. Marshall. Instead he clung to the presidency for nearly a year and a half, October 2, 1919, to March 4, 1921." ${ }^{\prime 4}$ Such an opinion is irrelevant and unjustified, considering Wilson did not retire and remained president until the end of his term.

Furthermore, Ferrell flip-flops on blaming Wilson's illness or stubbornness for various issues. For example, Ferrell argues that Wilson's illness made him unable to control the Committee on Public Information (CPI) during and after the war, but Ferrell blames Wilson's stubbornness for the failure of post-war peace talks in Paris. If Wilson was coherent enough for the post-war peace talks, he was well aware of what was going on with the CPI and civil liberties during the war. It is likely that a combination of hubris and poor health played a role in the majority of Wilson's politics near the end of his term, but it is unfair to erase him from his role in the 100 percent Americanism that placed many aliens and immigrant Americans in jail.

\footnotetext{
${ }^{13}$ Ibid., 156.

${ }^{14}$ Ibid.
} 
In 1986, Christine Lunardini expanded on the cultural historical approach of Kennedy and Lears with her work From Equal Suffrage to Equal Rights: Alice Paul and the National Woman's Party, 1910-1928. Receiving her Ph.D. from Princeton University, Lunardini studied under Arthur S. Link and thus, while she focuses on a component of American culture, she set it within the boundaries of politics. She argues that the work of Alice Paul and the National Women's Party was largely, if not entirely responsible for the passing of the Nineteenth Amendment, women's suffrage. ${ }^{15}$

Lunardini's book takes a chronological and detailed look at Alice Paul and her struggle to organize for women's suffrage. Starting with a brief biography of Paul's personal life and education, Lunardini explains how Paul became a charismatic leader and motivator. In 1913, a new generation of women developed who had higher education and urban, industrial and technological understanding. These new suffragists were more career-oriented and less apt to marry. As Lunardini explicates, women of this group questioned old assumptions and found inspiration in the British suffragists. Among this group of women was Alice Paul who obtained two law degrees, a Ph.D., and never married. Joining with the National American Woman Suffrage Association (NAWSA), these new suffragists felt dissatisfied. Indeed they desired to use militant tactics and argue for women's suffrage at the federal level. With the leadership of Paul, this group split from the NAWSA and eventually formed the political party, the National Woman's Party (NWP).

Using methods such as picket protests and organized marches, Paul and the NWP faced conflicts with NAWSA who promoted peaceful talks at the state level and the

${ }^{15}$ Christine Lunardini, From Equal Suffrage to Equal Rights: Alice Paul and the National Woman's Party, 1910-1928 (New York: toExcel Press. 1986). 
Democratic Party who did not support women's suffrage. Throughout World War I Paul and the NWP continued to raise money and protest outside the White House, facing arrest and physical harassment. Eventually, Wilson joined their cause and by 1920 the Nineteenth Amendment had finally passed. In her last chapter Lunardini explains the slow disbanding of the NWP and the difficulty of Paul to gather support for a new cause: the Equal Rights Amendment.

Lunardini's work offers insight into the women's movement during the Progressive Era and World War I. It is a cultural approach that focuses on a minority group of women. One critique of the book is that Lunardini is a feminist. While women's suffrage is a remarkable achievement, Lunardini is close-minded as to who worked to accomplish that great feat. She gives almost sole credit to Alice Paul and the National Woman's Party. It would benefit the credibility of the book, if Lunardini did not show such cheerleading of Paul and the NWP. Their efforts should be celebrated alongside the work of others, such as the NAWSA, who also aided in the movement. ${ }^{16}$

${ }^{16}$ In 1986, James T. Kloppenberg published Uncertain Victory: Social Democracy and Progressivism in European and American Thought, 1870-1920 (New York: Oxford University Press, 1986), in which he utilizes a cultural and intellectual approach, similar to Jackson Lears's, to compare the uncertain ideas about politics of Europeans and Americans. In 1992, Theda Skocpol published Protecting Soldiers and Mothers: The Political Origins of Social Policy in the United States (Cambridge, Mass.: Harvard University Press, 1992), in which she argues that the United States developed welfare programs for soldiers and their dependents and mothers and their children much earlier than the welfare programs of the New Deal. She claims that following the Civil War these welfare programs were implemented and lasted throughout the World War I period. As a political scientist she takes a different approach than typical historians, though she still offers solid historical scholarship on the time period. In 2003 Michael McGerr published A Fierce Discontent: The Rise and Fall of the Progressive Movement in America, 1870-1920 (New York: Free Press, 2003), in which he argues that progressivism created many of the current political problems of modern times because the "the creed of a crusading middle class, offered the promise of utopianism - and generated the inevitable letdown of unrealistic expectations." McGerr claims that such 
Shifting to the most recent literature in the historiography of this period, in 2006 David Traxel, professor at the University of the Sciences at Philadelphia, published Crusader Nation: the United States in Peace and the Great War, 1898-1920, which draws on a combination of the political, cultural and social histories of the 1960s, 1970s, and 1980s. It is an overview book that demonstrates how the people of the Progressive Era truly believed in what they advocated for and expected change to happen.

Ultimately, Traxel argues that World War I was both the culmination and defeat of progressivism. ${ }^{17}$ Moving chronologically, Traxel works his way from the Roosevelt's term through the passage of Prohibition and women's suffrage.

Traxel offers great biographical information on Roosevelt and Wilson who served during this period, allowing the reader to gain a sense of how they became progressive leaders. He also describes the reforms that they worked on during their individual presidential terms. In addition, Traxel presents detailed biographical information on nonpolitical reformers, such as Jane Addams, Mary Mother Jones and Henry Ford. Traxel utilizes a narrative history approach in which he provides historical context while using anecdotes and storytelling methods throughout the work. He incorporates cultural changes by addressing the introduction of ragtime music, new art forms and Edison's inventions, such as the phonograph. Socially he demonstrates reforms that crossed class lines, including labor strikes and birth-control promotions. Traxel touched on all of these

ambitious reforms led to eventual disappointment in the post-World War I period and American people would never jump onboard such idealistic reforms ever again. ${ }^{17}$ David Traxel, ('rusader Nation: The United States in Peace and the Great War, 18981920 (New York: Alfred A. Knopf: 2006). Traxel's book seems to draw largely from the work of Michael McGerr in the argument that Worid War I marked the climax and downfall of the progressive movernent. 
methodological approaches by utilizing the personal and public papers of the reformers involved, alongside government papers.

Traxel demonstrates how the preparation and patriotism behind World War I encouraged reformers to believe that change was possible. However, with the realities of the war loans, conscription, the Sedition and Espionage Acts, the Bolshevik Revolution and Wilson's failed peace talks, the American people lost their faith in idealistic reforms. Americans became more skeptical of supporting crusades for unrealistic changes. Traxel contends that with the election of Harding in 1920, the progressive movements of the previous twenty years came to an end.

Traxel's book does an adequate job of incorporating components of politics, society and culture. However, he sometimes loses the momentum of his argument with his anecdotal stories about various people. Traxel's book provides a nice overview and an interesting argument on the culmination and end of progressivism, though it can become unclear at times.

Also adding to the recent literature on the turn of the twentieth century scholarship is Christopher Capozzola with his 2008 work Uncle Sam Wants You: World War I and the Making of the Modern Citizen. Receiving his Ph.D. from Columbia in 2002, this work was Capozzola's first published book, which is often noticeable in his writing. Using a political and cultural approach, he examines the relationship between citizens, voluntary associations and the federal government during World War I. His work coined the concept of "coercive voluntarism," which implies citizens and the government putting pressure, or force if necessary, on other citizens to participate in the 
state-sponsored undertaking of warfare. ${ }^{18}$ He argues that the war mobilization for World War I had lasting effects on the nature of American citizenship. He contends that "coercive voluntarism" produced the contradicting outcomes of a strong federal government and a growing group of liberals/radicals who sought to fight back against state coercion and defend civil liberties.

Focusing largely on the poster and newspaper campaigns, while also acknowledging legislation passed during the war, Capozzola examines how the federal government enforced coercive voluntarism. His title comes from the poster of Uncle Sam, designed by James Montgomery Flagg in 1916, which illustrated an older man pointing his finger and saying "I want you for U.S. Army."19 Capozzola finds that such posters evoked political obligations out of American citizens, calling them to do their part for the country or else suffer the fear of mob violence or arrest. He explains that some patriotic Americans were so determined to enforce 100 percent Americanism that one had to distinguish between vigilant volunteers and vigilantism. With a lack of civil liberties consciousness, most Americans supported the growth of regulation by the federal government, especially with regards to aliens and radicals, for example German immigrants or pacifists. The easy passage in Congress of the Sedition and Espionage Acts support this claim. As a result civil libertarians began to develop civil liberties language and fight back against the increasing power of the federal government.

Capozzola's book is accessible to readers, asking new questions about the mobilization effort on the American home front during World War I. However, he often

\footnotetext{
${ }^{18}$ Christopher Capozzola, Uncle Sam Wants You: World War I and the Making of the Modern American Citizen (New York: Oxford University Press, 2008), 8.

${ }^{19}$ Ibid., 5 .
} 
makes overstatements regarding both the mob violence and the civil libertarians. Instead of analyzing the majority of American citizens he focuses on the loud minorities, such as the socialists. $^{20}$

Published in 2011, the last work for this particular historiography is Glen Gendzel's essay "What the Progressives Had in Common," which brings this study fullcircle through his usage of the political, cultural and social approaches. From his footnotes it is clear that he utilizes the arguments of the majority of the historians included in this chapter. In conclusion, he finds, as one could expect from the complexity of this historiography, that the Progressive period still remains a puzzle to historians today. He contends,

When Professor Benjamin Parke De Witt of New York University sat down to write the first history of the progressive movement in 1915, he promised 'to give form and definitiveness to a movement which is, in the minds of many, confused and chaotic.' Apparently it was a fool's errand, because confusion and chaos continued to plague historians of early twentieth-century reform long after Professor De Witt laid his pen to rest. The maddening variety of reform and reformer in the early twentieth century has perpetually confounded historians' efforts to identify what, if anything, the progressives had in common. ${ }^{21}$

While acknowledging that the Progressive Era is too difficult to try and understand completely, Gendzel contends that regardless of the differences among reformers all of

${ }^{20}$ In 2008, William H. Thomas Jr. published Unsafe for Democracy: World War I and the U.S. Justice Department's Covert Campaign to Suppress Dissent (Madison: The University of Wisconsin Press, 2008), in which he argues that although the Espionage and Sedition Acts were passed by the Legislature, the United States Justice Department went beyond the call of duty to suppress dissenters and radicals. Thomas focuses on the ideology of the U.S. government to conform Americans in the wartime period. In 2009, Melvin I. Urofsky published a biography of Louis D. Brandeis arguing that the man played four different roles: lawyer, reformer, jurist and Zionist. In conclusion he found that Brandeis was always an attorney first and foremost. Both Thomas and Urofsky used a combination of political and social history to understand the judiciary branch better. ${ }^{21}$ Glen Gendzel, "What the Progressives Had in Common," The Journal of the Gilded Age and Progressive Era 10 (July 2011): 331. 
them shared a collective will for progress through positive statism. Using Wiebe's nostalgia for the small town communities, Gendzel argues that reformers believed that the federal government could fill that void through regulation and protection of the people's interests. Gendzel cites an example of this phenomenon in his study of the 1912 election claiming that although all the candidates stood for different reforms, they all advocated a progressive interest through the means of a centralized government. While Gendzel's work is only an essay and requires much more research, he gets at the ultimate goal of this historiography to show the complexity of the Progressive Era and World War I period.

As emphasized early, this historiography is far from complete, but it offers a taste of both the complexities of the Progressive Era and World War I and the complexities of writing about the Progressive Era and World War I. One could spend a lifetime sifting through the source materials from that era and still walk away bewildered. Yet that complexity is also the appeal of continuing to study the period. It was a dramatic transitional period for the American people, in which they experienced modernization, urbanization, industrialization and internationalization. The era may be impossible to understand, but scholars recognize the era's fundamental significance in United States history. For the purpose of this study, it is essential for the reader to grasp the complexity of historical context in order to appreciate the role of Louis Brandeis in helping to shape the eventual jurisprudence of the freedom of speech in the post World War I years. 


\section{CHAPTER II}

\section{THE LIFE OF LOUIS D. BRANDEIS AND THE HISTORICAL CONTEXT OF CIVIL LIBERTIES}

The complexity that ran throughout the Progressive Era and World War I also ran throughout Louis Brandeis's career. The following biography and historiography of Brandeis will demonstrate the difficulty in finding a common thread between Brandeis's work on Progressive reforms, the Zionist movement, and Supreme Court jurisprudence. Brandeis valued evidence and approached every situation according to how he understood the evidence provided. In addition, Brandeis continued to educate himself over the course of his life and admitted to shifting his position on various issues when he felt he had misinterpreted the evidence the first time around. This chapter demonstrates where this thesis falls into the historiography of Louis Brandeis and civil liberties. Narrowing in on three freedom of speech cases in the post-World War I period, this paper displays how Louis Brandeis solidified his stance on free speech in a political democracy and provided the traction for future Supreme Court justices to grapple with the Founder's meaning of free speech.

\section{A Short Biography of Louis Brandeis}

Louis Brandeis was born on November 13, 1856 in Louisville, Kentucky. Brandeis's parents, Adolph and Frederika Brandeis, were immigrants from Eastern Europe who came to the United States to avoid the political and economic unrest and the 
anti-Semitic treatment they experienced under the Austrian-Hungarian Empire. After several years of barely making ends meet, Adolph Brandeis established a comfortable living for his family in the wheat industry. During the Civil War the Brandeis family supported the Union and the abolition of slavery. Some of Louis's early memories came from those years when he would take food and water out to Union troops passing through or based in Louisville.'

As the youngest of four, Brandeis was close to both his parents and siblings. His friendship with his brother, Alfred, lasted throughout their lives. Brandeis was also close to his extended family, the Wehle and Dembitz families. Frederika's brother, Lewis Naphtali Dembitz, proved to be Louis's role model; hence, the reason that Louis changed his middle name to Dembitz. Following in his uncle's example, Louis immersed himself in the Jewish faith and legal studies. ${ }^{2}$ In 1872 , Brandeis's immediate family spent three years in Europe during a lull in the grain economy in the United States. During that time Louis attended university in Dresden, Germany. It was in the course of his studies at Annen-Realschule in Dresden that he learned the importance of memorizing facts. Brandeis placed high value on factual evidence for the rest of his life. ${ }^{3}$

Upon his return home, he enrolled in Harvard Law School and earned his law degree. While at Harvard, Brandeis welcomed the 1870 curriculum changes that Professor Christopher Columbus Langdell introduced to the law school. Instead of using textbooks, Langdell required that his students read case studies in order to gain a sense of

\footnotetext{
${ }^{1}$ Melvin Urofsky, Louis D. Brandeis: A Life (New York: Pantheon Books, 2009), 10.

${ }^{2}$ Ibid., 19-20.

${ }^{3}$ Ibid., 28.
} 
the law in practice. ${ }^{4}$ In regards to Langdell's innovative teaching methods, Brandeis exclaimed, "The points thus incidentally learned are impressed upon the mind as they never could be by mere reading or by lectures; . . . for they occur as an integral part of the drama of life." ${ }^{5}$ Brandeis threw himself into investigating case studies to understand the evidence and the methodology behind how each case was argued and decided. When his eyesight failed him during his years at Harvard, Brandeis had to have other students read to him. Drawing upon his education in Germany, Brandeis learned to memorize the information so that he would be prepared for exams. ${ }^{6}$ In addition to his development at school, Brandeis learned first-hand as a poor graduate student that a person could survive on frugal means. He maintained this simplistic way of living for the entirety of his life, even when he had gained a substantial fortune.

For a short time after graduating, Brandeis worked at a law practice in St. Louis, Missouri, but in 1879, he decided to move back to Boston, Massachusetts. In Boston, he set up a law practice with his friend Sam Warren. Over the years the two men enjoyed a great deal of business and carried on a solid practice through the late nineteenth century. ${ }^{7}$ Eventually Warren left the partnership in order to run his family business, and therefore, in 1897 , Brandeis became a senior partner at the newly founded firm of Brandeis, Dunbar \& Nutter. As a senior partner, Brandeis filled the managerial and business role in the firm, while newly hired law graduates took over the majority of cases.

In 1891, alongside working at the practice, Louis Brandeis married Alice Goldmark from New York City. Together they had two daughters, Susan and Elizabeth.

\footnotetext{
${ }^{4}$ Alpheus Mason, Brandeis: A Free Man's Life (New York: The Viking Press, 1946), 34.

${ }^{5}$ Ibid., 35.

${ }^{6}$ Ibid., 46.

${ }^{7}$ Urofsky, 50-58.
} 
Even though he was making over a million dollars by the early twentieth century, Brandeis and his family continued to live a minimal lifestyle. And while establishing a life in New England, Brandeis and his family frequently traveled to Louisville to visit his parents and siblings. Family rested at the core of Brandeis's life. Even when he was unable to make it home to Louisville, Brandeis sent countless letters to his family members. ${ }^{8}$

Besides attending to his family and law practice, Brandeis also committed a large portion of his time to teaching at the Harvard Law School and other local universities and working on a number of major reforms. Teaching courses at Harvard kept Brandeis connected to the university and helped him identify qualified law students for his legal practice. The Progressive Era created many changes in the United States, in all realms of life including, society, politics, economics, and religion. Brandeis was a key figure in advocating for reforms through legal action Brandeis worked on a variety of reform issues, including limiting work hours, creating savings bank insurance, restraining monopolies and trusts, and creating safe working conditions. Whether representing as legal counsel, making speeches, or serving on a board, Brandeis stayed active in these reform movements. For his work on protective legislation, Louis Brandeis earned the nickname, "the people's attorney." As historian and Brandeis biographer Melvin Urofsky exclaimed, "While we will occasionally refer to a public-spirited lawyer taking on big interests as a people's attorney, that sobriquet will always and uniquely belong to Louis Brandeis." ${ }^{99}$

\footnotetext{
${ }^{8}$ Mason, 72-77.

${ }^{9}$ Urofsky, 227.
} 
A major component of Brandeis's enduring character developed out of his Jewish faith. While identifying as Jews, Brandeis and his family did not practice the Jewish faith ardently. Thus, despite the fact that most of Brandeis's first clients were Jewish, until 1910 Brandeis did not take a firm role in Jewish society. In an interview with Jacob de Haas, former secretary of Theodore Herzl who started the Zionist movement, de Haas inspired Brandeis to get involved in Zionism when he referred to Brandeis's uncle, Lewis Dembitz, as a "noble Jew." " Upon learning of his uncle's activism in the Jewish faith, Brandeis became interested in the Zionist work. He joined the Zionist organization in Boston and rose to a leadership position. Before his involvement, the Zionist movement lacked funds and focus. Brandeis resolved these problems by traveling the country and giving speeches in order to raise money and awareness for the Zionist mission. He even visited Palestine and other locations in Europe to develop the international ties of the organization. ${ }^{11}$ Though Brandeis never held deep religious beliefs, he believed that Jewish people deserved to establish a homeland where they would secure personal rights and feel safe from prejudice.

In January 1916, President Woodrow Wilson nominated Louis Brandeis to the Supreme Court. In the four months following the nomination, major debates took place in Congress over the confirmation of Brandeis. The two main reasons that Congress objected to his nomination were that he identified as a Republican and a Jew. Wilson's Democratic Party wanted a Democratic nominee and hesitated to confirm a Republican nominee who might not rule according to their Democratic philosophy. Furthermore, anti-Semitism ran throughout the United States at this time, thus the opposition to

${ }^{10}$ Lewis Paper, Brandeis (Fnglewood Cliffs: Prentice-Hall, Inc., 1983), 202.

11 Ibid., 206-208. 
Brandeis's Jewish background was not unusual. Nonetheless, on June 1, 1916, with Wilson's avid support of Brandeis's progressive background and competence, Congress confirmed Brandeis to the Supreme Court. ${ }^{12}$ Moving his family to Washington, D.C., Brandeis served on the Supreme Court from 1916 to 1939. Throughout this time Brandeis worked on reforms and remained active in the Zionist movement. He also published several works on his philosophies about law, economics, religion and society, including his most famous work, The Curse of Bigness, published in 1934. Two years after retiring, Brandeis suffered a heart attack and died on October 5, 1941. His wife, Alice, died four years later and both of their cremated bodies were placed under the entranceway of the University of Louisville's law school. ${ }^{13}$ Along with their remains, Brandeis left the majority of his personal papers to Louisville's law school.

Understanding the outline of Louis Brandeis's life helps one to appreciate the various roles that he filled over the course of his lifetime. Furthermore, it explains how he developed his approach to the freedom of speech cases that are examined in this study. The following historiography allows one to see the great interest that scholars have shown in Brandeis' life. By analyzing the contextual background of civil liberties in the United States and considering the circumstances of World War I and the Wilson administration, the following segment will also demonstrate the importance of Brandeis in shaping the eventual jurisprudence of the First Amendment. The following two historiographical essays break down the prior scholarship on Justice Brandeis and civil liberties and suggest where this essay fits into this historical field.

\footnotetext{
${ }^{12}$ Ibid., 212-213.

${ }^{13}$ Urofsky, 753-754.
} 


\section{Historiography of Louis D. Brandeis}

Louis D. Brandeis wore many different hats in his lifetime. From lawyer to Zionist leader to Supreme Court Justice, Brandeis affected numerous audiences. Toward the latter part of his life and in the seventy years since his passing, many scholars have written on his influence. The following historiography offers insight into the various approaches that have been made in trying to understand the true Louis Brandeis. Furthermore, this historiography presents characteristics of Brandeis's life and personality that help one to appreciate Brandeis's opinions on First Amendment cases in the post-World War I era.

In 1929, Jacob de Haas, a British scholar, journalist, and Jew, wrote Louis D. Brandeis: A Biographical Sketch. ${ }^{14}$ Published in Brandeis's lifetime, this book placed special emphasis on Brandeis's role in the Zionist movement in the United States. The admiration that de Haas held for Brandeis came through in his writing. Providing a brief biography of Brandeis's life growing up in Louisville and then studying at the University of Dresden in Germany, de Haas skipped ahead to the 1900s when Brandeis became active in the Zionist movement. Before Brandeis, de Haas argued that the Zionist movement in America was weak. When describing Brandeis, de Haas stated, "He does not expound views or ideas--he only puts them into action." ${ }^{\prime 15}$ From raising money during World War I, to visiting Palestine, to arguing cases for Jewish rights, de Haas demonstrated how Brandeis was an activist for the Zionist movement. While de Haas acknowledged that Brandeis also fought for the rights of other minority groups, he failed

\footnotetext{
${ }^{14}$ Jacob de Haas, Louis D. Brandeis: A Biographical Sketch (New York: Bloch Publishing Company, 1929).

${ }^{15}$ Ibid., 44.
} 
to detail Brandeis's accomplishments for these groups. It is clear that de Haas wrote in promotion of the Zionist movement and used Brandeis as its figurehead in the United States.

Publishing several articles and books in his lifetime, The Curse of Bigness: Miscellaneous Papers of Louis D. Brandeis proved to be one of Louis Brandeis's most eminent works. ${ }^{16}$ Published in 1934, the book consists of a compilation of Brandeis's speeches, opinions, and articles on the evils of big business in life insurance, industry, trusts, railroads, government, public service, and finance. ${ }^{17}$ Throughout his work, Brandeis made it clear that he supported competition, but with certain regulations. He explained that without regulation, competition shifted in the direction of large trusts and monopolies. When that happened, he recognized that working class and often middle class people lacked fair opportunity for economic advancement. Through his role as a lawyer and Associate Justice of the United States Supreme Court, Brandeis argued and ruled against trusts and big financial machines. In his 1890 article, "The Right to Privacy," co-written with Samuel Warren, his legal practice partner, Brandeis explained:

Now the right to life has come to mean the right to enjoy life--the right to be left alone, the right to liberty secures the exercise of extensive civil privileges; and the term "property" has grown to comprise every form of possession-intangibles, as well as tangible. ${ }^{18}$

Brandeis contended that the individual's right to privacy extended to politics, society, and economics and that big business and big government limited a person's liberties.

Brandeis and Warren believed that while individual and property rights existed since

\footnotetext{
${ }^{16}$ Louis Brandeis, The Curse of Bigness: Miscellaneous Papers of Louis D. Brandeis, edited by Osmond K. Fraenkel (New York: Viking Press, 1934).

${ }^{17}$ Ibid., iv.

${ }^{18}$ Louis Brandeis and Samuel Warren, "The Right to Privacy," Harvard Law Review, IV (1890).
} 
before the American Constitution, the defining of these rights needed to be updated over time. This same perspective of Brandeis is seen in his dealings with the First Amendment cases in this essay. While individual rights had expanded to such issues as emotions and intangible belongings, Brandeis and Warren argued further that the right to privacy was a component of an individual's right as well. They explained that what a person said or did in the privacy of their own home was to be protected just as ardently as a person's physical possessions. This source is crucial to identifying Brandeis's reasoning for his judicial rulings on civil liberties.

In 1936, Alfred Lief took a different approach to Brandeis's biography in Brandeis: The Personal History of an American Ideal. ${ }^{19}$ Instead of focusing in on Brandeis's Zionist leadership, Lief grappled with Brandeis's personal philosophy in life. Lief published his book while Brandeis was in his last years of serving on the Supreme Court. Lief used interviews as his main source of information for identifying Brandeis's philosophical beliefs. He interviewed numerous judges, lawyers, politicians, religious leaders, and friends of Brandies, who all spoke highly of Brandeis's honesty and work ethic. Albert Einstein claimed, "I treasure the memory of my only visit to him: a person of swift and clear insight, of keen conviction, wanting nothing but to serve society, and serving in the loneliness of great work. ${ }^{20}$ Lief took his reader through Brandeis's life from childhood through his struggle to be confirmed to the Supreme Court. Along the way, Lief utilized his interviews with people that Brandeis worked or interacted with at various stages in his life. The priceless interview material in Lief's work of many people

\footnotetext{
${ }^{19}$ Alfred Lief, Brandeis: The Personal History of an American Ideal (New York: Stackpole Sons, 1936).

${ }^{20}$ Ibid., 13.
} 
who are now deceased is vital information to the understanding of Brandeis. However, Lief failed to pinpoint what American ideal that Brandeis subscribed to in his hope for all Americans.

In 1946, Professor Alpheus Mason of Princeton University published Brandeis: A Free Man's Life. ${ }^{21}$ Beyond the classroom, Mason devoted his life to writing biographies of Supreme Court justices. In 1940, Louis Brandeis consented to Mason writing his biography and allowed Mason access to all of his public and personal papers. Mason also had the privilege of meeting with Brandeis on numerous occasions to discuss various components of his life. After Brandeis's death in 1941, Mason gathered information from Brandeis's friends and family, including Mrs. Alice Brandeis. Mason presented the contradiction of Brandeis in the minds of the American public. He contended, "All agree that Brandeis's achievements are remarkable, but as to the nature of his talents, as to the mainspring of his life and work, opinions are varying and contradictory." 22 By highlighting the critiques of Brandeis's life, such as his fight against big business as a multimillionaire, Mason explained that Brandeis maintained consistency and purpose throughout his life. Mason found that by living a frugal existence with his wife, Brandeis donated to various groups he supported, such as savings-bank life insurance, the University of Louisville, and Zionist organizations. In his will, he left large sums of money to his wife and children with a hope that they would continue to give to charitable

\footnotetext{
${ }^{21}$ Alpheus Mason, Brandeis: A Free Man's Life (New York: The Viking Press, 1946). Alpheus Mason also published Bureaucracy Convicts Itself in 1941 on the BallingerPinchot case involving Louis Brandeis. However, Brandeis: A Free Man's Life is used for this study because it covers a broader range of Brandeis and his impacts on U.S. law and society. According to Mason's obituary in the New York Times, this book sold over 50,000 copies and stayed on the best-seller list for five months upon its release.

${ }^{22}$ Ibid., 4.
} 
causes. Besides finances, Mason found that many critiqued Brandeis for not choosing to be a conservative or liberal and for either being a Jew or not being a radical Zionist. To counter these critiques, Mason's overall thesis claimed, "The dominant strain in Brandeis and in his heritage was an urgent zeal for freedom."23 While some scholars found Brandeis to be contradictory, Mason argued that throughout his life, Brandeis stood firmly by his independence and freedom in every decision he made.

Shifting to a comparative approach, in 1956, scholar Samuel J. Konesfsky published The Legacy of Holmes and Brandeis: A Study in the Influence of Ideas. ${ }^{24}$ One of many scholars to write about the relationship between Supreme Court Associate Justices Oliver Wendell Holmes and Louis Brandeis, Konesfsky argued that while the two men differed in their intellectual judgments, social networks, and political principles, they shared a common understanding of the United States Constitution. By the time that Louis Brandeis joined the Supreme Court in 1916, Holmes had served on the court for fourteen years. However, it became clear through voting and opinion writing that Holmes and Brandeis interpreted the law in a similar manner. For the sake of this essay, Konefsky's chapter ten, "If Authority Is to Be Reconciled with Freedom," addresses the cases in this study by examining how Holmes and Brandeis ruled on First Amendment cases in the post-World War l period. Konefsky contended that both men valued evidence over anything else in judicial decision-making and both men often drew the same conclusions from the evidence of various cases. Konefsky stated, "The harmony between Justices Holmes and Brandeis is as illuminating a commentary upon the

\footnotetext{
${ }^{23}$ Ibid., 641.

${ }^{24}$ Samuel J. Konefsky, The Legacy of Holmes and Brandeis: A Study in the Influence of Ideas (New York: Collier Books, 1956).
} 
essentially flexible nature of America's fundamental charter as one can expect to find in the whole field of judicial biography." 25

Over the period from 1971 to 1978, historians Melvin Urofsky and David Levy published five volumes of Brandeis's personal letters. The two volumes pertinent to this project include the letters that Brandeis wrote from 1916 to 1941 in volumes four and five of the series. ${ }^{26}$ In the fourth volume, the editors compiled the letters written by Brandeis from 1916 to 1921 . The first half of this volume incorporates the letters that Brandeis wrote from Boston to various people in Washington about his credentials for serving on the Supreme Court. When President Woodrow Wilson nominated Brandeis to the Supreme Court a public outcry arose for two main reasons. First, Louis Brandeis aligned himself with the Republican Party and many members within Wilson's Democratic Party preferred a Democratic nomination. Secondly, Louis Brandeis was Jewish and anti-Semitism was a common sentiment among Americans at this time. Many Americans associated being Jewish with being a Socialist. However, President Wilson appreciated Brandeis's contributions to the Progressive movement in politics and society and stood by his nomination during the months that it took to confirm Brandeis to the Supreme Court. During that time, Brandeis wrote to stay abreast of what was being said and to clarify aspects of his resume. The second half of the volume is dedicated to the letters that Brandeis wrote to various members of the Zionist organization. Urofsky and

\footnotetext{
${ }^{25}$ Ibid., 279.

${ }^{26}$ Louis Brandeis, Letters of Louis D. Brandeis: Volume IV (1916-1921): Mr. Justice Brandeis, edited by Melvin Urofsky and David Levy (Albany: State University of New York Press, 1975); Louis Brandeis, Letters of Louis D. Brandeis: Volume V (1921-1941): Elder Statesman, edited by Melvin Urofsky and David Levy (Albany: State University of New York Press, 1978); For more primary source material on Brandeis during his Supreme Court years see Alexander M. Bickel's The Unpublished Opinions of Mr. Justice Brandeis (Chicago: The University of Chicago Press, 1967).
} 
Levy explained that this emphasis on Zionist letters was due to the fact that once Brandeis was on the Supreme Court, he was unable to write on judicial matters. Instead, he would meet privately with friends and family to discuss political and judicial issues. Therefore, these letters help to gain a better sense of Brandeis during his first years on the court. As Urofsky and Levy explained, "These letters record his controversies, his activities, his observations, and his hopes. ${ }^{27}$ In the fifth volume, Urofsky and Levy included letters from 1921 to Brandeis's death. The letters from this time period demonstrate how active Brandeis was in an assortment of different projects. Urofsky and Levy concluded:

Indeed, some of his finest and most enduring work, the preservation of a constitutional heritage open to flexibility and innovation and the protection of individual rights and privileges, took place during these years, and Brandeis had the good fortune to see some of his great dissents later become the law of the land. $^{28}$

These letters are significant in demonstrating how Brandeis balanced his personal life with his role on the Supreme Court. In his last twenty years of life, Brandeis did not slow down. In fact, his letters during that time show the opposite.

In 1983, lawyer Lewis Paper published Brandeis, a biography of Louis D. Brandeis. ${ }^{29}$ His work was one of the first to demonstrate the significance of Brandeis's impact on United States history. Living through the Civil War, the Industrial Revolution, the Progressive movement, the First World War, the Zionist movement, the Great Depression, and the start of World War II, Paper argued that Brandeis played a large role in how the United States handled these dramatic events through legal practice,

\footnotetext{
${ }^{27}$ Letters of Louis D. Brandeis: Volume $I V$ xv.

${ }^{28}$ Letters of Louis D. Brandeis: Volume $V$, xvi.

${ }^{29}$ Paper, Brandeis.
} 
presidential advising, and judicial service. Paper referred to Brandeis's role in the Zionist movement as an example of his philosophy in all realms of life. Paper contended that Brandeis was not a deeply religious man. Instead, he supported the Jewish homeland in Palestine because he wanted everyone to have the opportunity to embrace his or her personal freedoms. As Paper explained, "In every instance [Brandeis] was working for his vision of what society should be-a place where people could control their environments and maximize the chances of fulfilling their potential. ${ }^{930}$ From childhood to death, Paper showed how Brandeis affected important events in America's history. As a lawyer, Paper emphasized Brandeis as a role model and teacher for law students, such as himself.

In 1984, American scholar Philippa Strum followed Lewis Paper's work with Louis D. Brandeis: Justice for the People. ${ }^{31}$ With a background in American civil liberties and United States constitutionalism, Strum emphasized Brandeis's role in the fight for the working class people. During the Industrial Revolution, Strum argued that Brandeis saw a need for balance between employers and employees, in which both sides made joint decisions for the good of the company and the individuals involved. Strum contended that Brandeis drew his philosophy from Thomas Jefferson, the ancient Greeks and the Hebrew faith. She explained:

Brandeis and Jefferson held startlingly similar ideas about men and the body politic; the goodness but fallibility of human beings; democracy as the best possible political system; the central role of education in democracy; the inability of economically dependent citizens to be politically independent; the desirability

\footnotetext{
${ }^{30}$ Ibid., 4.

${ }^{31}$ Philippa Strum, Louis D. Brandeis: Jlistice for the People (Cambridge, MA: Harvard University Press, 1984); For further reading on Philippa Strum's research read Brandeis: Beyond Progressivism (Lawrence: University Press of Kansas, 1993).
} 
of small, controllable goverrmental units as close as possible to the people being government. $^{32}$

Making these connections, Strum demonstrated how Brandeis modernized Jefferson's ideas to fit the needs of twentieth century America. She also showed how Brandeis used the ancient Greeks as an example of a population that embraced democracy and demonstrated a self-fulfilled community. She argued that Brandeis's support of Zionism rested on the fact that he hoped the Jewish state would resemble the democratic polis of Athens. Finally, Strum explained that Brandeis"s "inner harmony" was the result of his Hebraic background. ${ }^{33}$ Just as the Hebrew slaves sought to escape the Pharaoh's control, Brandeis sought to free workers from the control of big business employers. While limited by the lack of sources on Brandeis's personal life, Strum claimed to have done her best to demonstrate the similarities that ran throughout Brandeis's public and private life, including his fight for the right to privacy.

Following their publication of the five volumes of the letters of Louis Brandeis, in 1991 Melvin Urofsky and David Levy worked together again to produce "Half Brother, Half Son": The Letters of Louis D. Brandeis to Felix Frankfurter. ${ }^{34}$ The majority of the 671 letters from Brandeis to Felix Frankfurter were unavailable at the time of their previous volumes. While they acknowledged that it would have been beneficial to

\footnotetext{
${ }^{32}$ Ibid., $x$.

${ }^{33}$ Ibid., 416.

${ }^{34}$ Louis Brandeis, "Half Brother, Half Son": The Letters of Louis D. Brandeis to Felix Frankfurter, edited by Melvin Urofsky and David Levy (Norman: University of Oklahoma Press, 1991); For more work on the Brandeis and Frankfurter relationship see Leonard Baker's Brandeis and Frankfurter: A Dual Biography (New York: Harper \& Row, 1984) and Nelson Lloyd Dawson's Louis D. Brandeis, Felix Frankfurter and the New Deal (Hamden: Archon Books, 1980); For more primary source material on Louis Brandeis see Urofsky and Levy's The Family Letters of Louis D. Brandeis (Norman: University of Oklahoma Press, 2002).
} 
publish the letters to Frankfurter within the context of the other letters, Urofsky and Levy found that a separate collection helped to highlight the significant relationship between the two men. Besides immediate family members, Frankfurter was the only person that Brandeis wrote to about personal matters and matters of the Supreme Court. Though usually brief correspondences, these letters reveal concerns and interests of Brandeis over the course of their friendship. Using the format of publishing the letters in a whole volume, Urofsky and Levy hoped to allow readers to make up their own minds about the relationship between Brandeis and Frankfurter. While disagreeing with previous scholars who criticized Frankfurter and Brandeis for using their alliance to push their own agendas through government, Urofsky and Levy acknowledged the influence of the two men and left the rest of the interpretation up to the reader. As they explained, "Presenting these letters in isolation, therefore, will illuminate aspects of the character and opinions of both men in ways that would have been harder to see and appreciate had they been published amidst letters to others. ${ }^{\circ 55}$ The Frankfurter-Brandeis friendship began in 1910 and their correspondence continued until Brandeis's death in 1941. Reading the letters that Brandeis sent during the post-World War I period is important to this essay in revealing some of the thoughts and feelings that Brandeis held during the hearings on several First Amendment cases.

Bringing this historiography into the twenty-first century, in 2007, legal historian G. Edward White published The American Judicial Tradition: Profiles of Leading American Judges. ${ }^{36}$ Researching the continuities and changes of the judiciary over the

${ }^{35}$ Ibid., 3.

${ }^{36}$ G. Edward White, The American Judicial Tradition: Profiles of Leading American Judges, $3^{\text {rd }}$ ed. (Oxford: Oxford University Press. 2007). 
years, White included sixteen chapters on various judges that he deemed significant. Chapter seven, entitled, "Holmes, Brandeis, and the Origins of Judicial Liberalism," is highlighted here for the specific purpose of this essay. The first part of the chapter is dedicated to demonstrating the difference between older thoughts on liberalism and modern liberalism. In modern liberalism, White contended that individuals use the government to restore values in society. To rescue minority groups from unequal treatment, Holmes and Brandeis ruled in favor of government protection of civil liberties. Similar to Konefsky, White acknowledged the personal differences between Holmes and Brandeis while illuminating their similar philosophies on regulating legislation on individual freedoms, such as free speech. The issue for these men rested in the fact that the post-World War I period was one of judicial restraint. White explained:

The speech cases represented one such instance in which judicial self-restraint did not produce liberal results. Holmes and Brandeis, both of whom, in varying degrees, believed in tolerating legislative judgments and in vindicating free expression, struggled with the dilemma posed by these cases. ${ }^{37}$

White contended that Brandeis and Holmes constituted key figures in the conceptualization of modern liberalism through their efforts in grappling with the conflict between liberal modes of judging and liberal results.

The most recent biography to be added to this historiography is historian Melvin Urofsky's Louis D. Brandeis: A Life, which he published in $2009 .{ }^{38}$ Urofsky argued that Brandeis played four different roles throughout his lifetime: lawyer, reformer, jurist and Zionist. In conclusion he found that Brandeis was always an attorney first and foremost.

\footnotetext{
${ }^{37}$ Ibid., 151.

${ }^{38}$ Melvin I. Urofsky, Louis D. Brandeis: A Life (New York: Pantheon Books, 2009); For a critique of this book see Paul Brickner's "Book Review: Louis D. Brandeis: A Life," Albany Government Law Review 507 (2011): 955. Brickner criticizes Urofsky for giving Brandeis too much praise and overly emphasizing his role in the Zionist movement.
} 
Urofsky explained that "[Brandeis's] attraction to the law derived in part from his belief that law provided the ideal means by which free men could impose order on their behavior and at the same time allow the greatest liberty for each person." ${ }^{.39}$ Unlike other idealists of the period, Urofsky contended that through pragmatism, Brandeis converted all of his ideals into realities. In all realms of his life, both personal and public, he approached problems like a lawyer approaching a case. He analyzed the evidence and sought solutions that coincided with the democratic and individual freedoms of the United States Constitution. Using personal papers, letters, government documents, Zionist records, interviews and an assortment of other sources, Urofsky presented a one thousand-page book on the life and impact of Brandeis. His two hundred pages of endnotes alone have added significantly to the study of Louis Brandeis.

This historiography highlights a sampling of the many scholarly works that have been published on and by Louis Brandeis. Understanding prior scholarship helps both to educate the reader on the significance of Brandeis and to show the void in studies on his life and work. This particular study will add to the historiography by taking a focused look at Brandeis's role in the shaping of First Amendment jurisprudence. It will draw on the works in this historiography for biographical information, source material, and a clearer understanding of Brandeis's philosophy on law and life.

\section{Historiography of Civil Liberties}

Before analyzing the specific Supreme Court cases in this study, it is also useful to recognize the arguments of historians who have previously examined the subject of

${ }^{39}$ Ibid., ix. 
civil liberties in World War I under President Woodrow Wilson's administration. In 1919, two members of President Wilson's cabinet wrote on the subject of the wartime Espionage and Sedition policies and the Committee on Public Information (CPI). Special assistant to the Attorney General, John Lord O'Brian, wrote "Uncle Sam's Spy Policies: Safeguarding American Liberty during the War" in order to defend the repressive acts employed by the Justice Department during the war. He contended that "the American spirit of fair play did not permit excesses to occur, with the exception of certain groups whose activities constituted willful attempts to interfere with conduct of war. ${ }^{, 40}$ Also, in defense of the president's policies was George Creel, head of the Committee on Public Information. In 1920, he published the book How We Advertised America: The First Telling of the Amazing Story of the Committee on Public Information that Carried the Gospel of Americanism to Every Corner of the Globe. The book condemned those people who argued that the wartime policies were too strict. It denounced that the government was trying to promote "spy hysteria" and contended that the committee helped the nation to gain its eventual victory at war. ${ }^{41}$

Conversely, in 1919, Zechariah Chafee, Jr., a Harvard Law Professor, published "Freedom of Speech in War Time." 42 The First Amendment concerned Chafee. He recognized the repression of civil liberties by the United States government as a growing problem. Paul Murphy described him as "one of the first to recognize that civil liberties

\footnotetext{
${ }^{40}$ John Lord O'Brian, "Uncle Sam's Spy Policies: Safeguarding American Liberty during the War," The Forum 61 (April 1919), 407-416.

${ }^{41}$ George Creel, How We Advertised America: The First Telling of the Amazing Story of the Committee on Public Information that Carried the Gospel of Americanism to Every Corner of the Globe (New York: Harper \& Brothers, 1920).

${ }^{42}$ Zechariah Chafee, Jr., "Freedom of Speech in War Time," Harvard Law Review 32 (June 1919), 933-961.
} 
was not only a matter of legal doctrine. but of politics as well, he both encouraged popular concern with the issue and deplored those who would turn the question into a smoke screen behind which to hide their selfish purposes."43 Chafee's argument was not widely accepted at the time and the study of the civil liberties movement lost its momentum until the later 1930 s as the threat of a new world war loomed.

In the late 1930 s and early 1940 s several works opposed the wartime policies of World War I in the United States. In 1939, James R. Mock and Cedric Larson published Words that Won the War to critique the Committee on Public Information and George Creel's leadership. ${ }^{44}$ In addition, H. C. Peterson wrote Propaganda for the War: The Campaign Against American Neutrality and James M. Read wrote Atrocity Propaganda, 1914-1917 which both described the manipulation of propaganda used by President Wilson's administration to enforce government policies and suppress dissension. ${ }^{45}$ Chafee wrote again at this time on the freedom of speech. He warned of a recurrence of World War I repression of freedom of speech in World War II. ${ }^{46}$ All of these works were representative of the concerns leading up to the Second World War from a civil libertarian stance. The authors wrote to bring attention to an elite group of scholars, legislators, and lawyers. They raised the issue of government censorship to keep it from happening again in the likely chance of another war.

\footnotetext{
${ }^{43}$ Murphy, World War I, 18.

${ }^{44}$ James R. Mock and Cedric Larson, Words that Won the War (Princeton: Princeton University Press, 1939).

${ }^{45}$ H. C. Peterson, Propaganda for War: The Campaign Against American Neutrality (Norman: University of Oklahoma Press, 1939); James M. Read, Atrocity Propaganda, 1914-1917 (New Haven: Yale University Press, 1941).

${ }^{46}$ Zechariah Chafee, Jr., Free Speech in the United States (Cambridge, Mass.: Harvard University Press, 1941).
} 
After World War II, not a lot was written initially because of the Cold War tensions and the McCarthy hysteria of seeking out communists among the American population and arresting them. However, in 1963, Donald Johnson wrote The Challenge to American Freedom: World War I and the Rise of the American Civil Liberties Union to attack the Justice Department for allowing such repressions on civil liberties to be enforced. ${ }^{47}$ He was followed by a series of 1960 s writers who all blamed different people for the civil liberty issues of World War I. Harry Scheiber blamed power-seeking cabinet members such as Attorney General Gregory, Richard P. Longakers blamed Wilson's lack of concern for liberties in the face of war, Thomas A. Lawrence blamed nativists who feared immigrants, and William Preston blamed power elites for tricking middle-class Americans into believing they had rights to certain liberties. ${ }^{48}$ In the post-Vietnam era, many pacifists added to the historiography in an effort to speak out against war and militarism, including Charles Chatfield and C. Roland Marchand. ${ }^{49}$

In 1975, Richard C. Cortner published The Supreme Court and Civil Liberties Policy, in which he addressed two main issues. ${ }^{50}$ First, he examined how the national Bill of Rights was applied to the states through the Fourteenth Amendment. Yet, he

\footnotetext{
${ }^{47}$ Donald Johnson, The Challenge to American Freedom: World War I and the Rise of the American Civil Liberties Union (Lexington, Ky.: University of Kentucky Press, 1963).

${ }^{48}$ Harry N. Scheiber, The Wilson Administration and Civil Liberties, 1917-1921 (Ithaca: Cornell University Press, 1960); Richard P. Longakers, The Presidency and Individual Liberties (Ithaca: Cornell University Press, 1961); Thomas A. Lawrence, "Eclipse of Liberty: Civil Liberties in the United States during the First World War," Wayne Law Review 21 (1974), 33-112; William Preston, Aliens and Dissenters: Federal Suppression of Radicals, 1903-1933 (Cambridge, Mass.: Harvard University Press, 1963).

${ }^{49}$ Charles Chatfield, For Peace and Justice, 1914-1941 (Knoxville: University of Tennessee Press, 1971); C. Roland Marchand. The American Peace Movement and Social Reform (Princeton: Princeton University Press, 1972).

${ }^{50}$ Richard C. Cortner, The Supreme Court ana' Civil Liberties Policy (Palo Alto: Mayfield Publishing Company, 1975).
} 
explained that the process of incorporation took time to be applied to the states even after Congress added the Fourteenth Amendment to the federal Bill of Rights after the Civil War. $^{51}$ In the first chapter of the book, he traced the gradual application process of the federal Bill of Rights to the states. In the second and main component of his book, Cortner presented six United States Supreme Court cases, near to the time of his publication in the 1970 s, to demonstrate how civil liberties policy had developed in the twentieth century. He argued that the Supreme Court's shifting interpretation of the Fourteenth Amendment over the decades caused the shift in how Americans understood modern civil liberties. Aiming his book at undergraduate audience, Cortner made his analyses concise and to the point. He intended to demonstrate that just as with any component of history, "the field of constitutional policy as enunciated in Supreme Court decisions is one of both continuity and change." 52 Through the example of Supreme Court rulings on civil liberties, Cortner provided evidence of the continuities and changes in the history of constitutional policy.

\section{In 1979, Paul L. Murphy's World War I and the Origin of Civil Liberties in the} United States added one of the most comprehensive studies of President Wilson's World War I policies and how the civil liberties movement developed in its wake. He asked the questions, "Why did they take place, and why, particularly, did they take place at this time? And, perhaps more importantly, what immediate and long-range reactions and implications in doctrinal, attitudinal, and behavioral terms did this development produce in American history?"53 His work serves as a fundamental resource for context on the

\footnotetext{
${ }^{51}$ Ibid., 1-2.

${ }^{52}$ Ibid., vii.

${ }^{53}$ Murphy, World War I, 25.
} 
Wilson administration, Espionage and Sedition Acts, and the formation of the American Civil Liberties Union.

In 1987, Richard Polenberg published Fighting Faiths: The Abrams Case, the Supreme Court, and Free Speech, which focused on the 1919 judicial decision in the Abrams v. United States case. In the book he identified the case as a landmark to the definition of free speech in the United States. He presented the evidence of the case and then analyzed the dissenting judicial opinion of Associate Justice Oliver Wendell Holmes and Associate Justice Louis Brandeis. His work shifted the historiography from a broad perspective of the civil liberty issues in World War I to a specific case study, in order to reveal the controversy of freedom of speech on its most basic levels. ${ }^{54}$ In 1999, Samuel Walker wrote In Defense of American Liberties: A History of the ACLU, which was also a directed study of one particular group that was born as a result of the World War I policies in the United States. Walker argued that as a consequence of World War I the ACLU established itself and played an influential role in the judicial trials of the twentieth century, raising issues of civil liberties throughout the United States. ${ }^{55}$

Richard Parker's 2003 work, Free Speech on Trial: Communication Perspectives on Landmark Supreme Court Decisions, was a compilation of legal scholars' essays. The essays focused on the constitutionality of First Amendment and how free speech has been interpreted over the years. By drawing on appellate decisions and legal theory, the essays explored the freedom and restraints that have been placed on the First Amendment over

\footnotetext{
${ }^{54}$ Richard Polenberg, Fighting Faiths: The Abrams Case, the Supreme Court, and Free Speech (New York: Penguin Books, Ltd, 1987).

${ }^{55}$ Samuel Walker, In Defense of American Liberties: A History of the ACLU

(Carbondale: Southern Illinois University Press, 1999).
} 
the years. ${ }^{56}$ In 2008, Daniel Farber published Security versus Liberty: Conflicts between Civil Liberties and National Security in American History. Farber wrote in response to the September 11, 2001 terrorist attacks in New York City. Along with the help of other historians, Farber argued that previous threats to national security in the twentieth century United States were the cause of President George W. Bush's strict security measures taken following the incident. Starting with World War I, Farber and historian, Alan Brinkley, discussed how President Wilson's administration aimed at silencing radical groups, such as socialists and anarchists, in order to dispel American notions of opposing the war. In the same way, though perhaps over-the-top, Farber contended that Bush's administration used Al-Qaeda members as radical scapegoats to protect internal security. Farber claimed that civil liberties were not indisputable. He explained that they are transformed with the present circumstances, as has been shown over the past century of United States history. ${ }^{57}$

In 2008, William H. Thomas Jr. published Unsafe for Democracy: World War I and the U.S. Justice Department's Covert Campaign to Suppress Dissent. ${ }^{58}$ In his study, Thomas argued that "An examination of the records of the Justice Department's Bureau of Investigation reveals that in 1917 and 1918 the department engaged in a massive and largely secret effort, unprecedented in American history, to suppress opposition to the

\footnotetext{
${ }^{56}$ Richard Parker, Free Speech on Trial: Communication Perspectives on Landmark Supreme Court Decisions (Tuscaloosa: University of Alabama Press, 2003).

${ }^{57}$ Daniel Farber, Security versus Liberty: Conflicts between Civil Liberties and National Security in American History (New York: Russell Sage Foundation, 2008).

${ }^{58}$ William H. Thomas Jr. Unsafe for Democracy: World War I and the U.S. Justice Department's Covert Campaign to Suppress Dissent (Madison: The University of Wisconsin Press, 2008).
} 
war. ${ }^{, 59} \mathrm{He}$ claimed that with the increase in progressives in political office, they pushed for larger government power and in turn a greater role of the Justice Department in the war effort. Thomas contended that the Justice Department conducted massive investigations of people suspected of dissenting from the war cause. In addition, the Justice Department took responsibility for suppressing vigilante groups that sought to injure or kill opponents of the war. ${ }^{o l}$ By analyzing these roles played by the Justice Department, Thomas set his study apart from the majority of studies that strictly focused on the role that the Justice Department played in ruling on court cases prosecuting seditious acts during the war. In reality, Thomas argued that the Justice Department spent much more time searching for and questioning people suspected of sedition during the war. ${ }^{61}$ Thomas's work offers a unique examination of the role of United States Justice Department outside of the courtroom.

In 2010, Robert G. McCloskey published the latest edition of The American Supreme Court. ${ }^{62}$ His work is part of the Chicago History of American Civilization series that includes both chronological and topical works. Publishing the first edition of this book in 1960, McCloskey presented a concise overview of how the United States Supreme Court originated and developed over the past two centuries. He contended that judicial review, established in 1803 in the case of Marbury v. Madison, shaped the future of the Supreme Court. ${ }^{63}$ Over the course of his book, he highlighted the shifting emphases of the court. For example, he explained that the first half of the nineteenth

\footnotetext{
${ }^{59}$ Ibid., 3.

${ }^{60}$ Ibid., 3-6.

${ }^{61}$ Ibid., 172.

${ }^{62}$ Robert G. McCloskey, The American Supreme Court (Chicago: The University of Chicago Press, 2010).

${ }^{63}$ Marbury v. Madison. 5 U.S. 137 (1803).
} 
century, the Supreme Court dedicated itself to resolving problems of the Union. Post 1937, McCloskey argued that the Supreme Court focused its attention on civil rights. Overall, McCloskey demonstrated the significant impact that the Supreme Court has made in United States history.

This expansive historiography explains where historians find themselves in regard to civil liberties in the United States. Understanding these works is vital to the interpretation of the following cases in this study. It is evident from these historical works that the controversies over the First Amendment in World War I played a powerful role in the shaping of jurisprudence for the First Amendment in the twentieth century to the current era. Digging down to the root of the civil liberties movement of World War I, one can find that a rarified civil liberties consciousness grew out of Supreme Court decisions that ruled on the Espionage and Sedition Acts in the post-World War I period.

\section{Conclusion}

This historiography is two-fold. It draws on the scholarship of Louis Brandeis and civil liberties in order to give readers a sense of the various arguments that have been made about Brandeis and civil liberties during the late 1910s and early 1920s. Understanding Louis Brandeis's philosophies is just as important as understanding the nature of civil liberties during his lifetime. Through an intensive studies of three First Amendment cases in the post-World War I period, this essay will demonstrate the relationship between Louis Brandeis and the beginnings of a civil liberties awareness in the United States. 


\section{CHAPTER III}

\section{THINKING THROUGH RATHER THAN AT THE FREEDOM OF SPEECH:}

BRANDEIS'S ROLE IN ABRAMS V. UNITED STATES

\section{Background to Judicial Thought About Speech and Press Prior to World War I}

Before 1917, civil liberties, specifically the freedom of speech and press, played a small role in American culture. In 1798, Congress enacted and President John Adams signed the Alien and Sedition Acts in order to suppress the dissenting opinions of Jeffersonians during the war with France. Led by Thomas Jefferson, the Jeffersonians saw the Alien and Sedition Acts as a direct threat to personal freedoms and state power. Historian Kermit Hall explained in his work The Magic Mirror: Law in American History that "the measure which imposed a penalty for publishing material creating distrust of the federal government, did not apply to any statements made against Thomas Jefferson, Adam's vice-president. Moreover, the Alien and Sedition Acts were timed to expire the day before Adams's term ended." By dissolving the acts before leaving office, the incumbent party opened the door for people to once again speak out against the government, in particularly, Thomas Jefferson, the incoming President. The lack of public opinion toward the short-lived Alien and Sedition Acts demonstrated the lack of

\footnotetext{
${ }^{1}$ Kermit L. Hall and Peter Karsten, The Magic Mirror: Law in American History, $2^{\text {nd }}$ ed. (New York: Oxford University Press, 2009), 81.
} 
public knowledge or concern towards how John Adams and Congress limited the rights of the First Amendment.

The next time that Americans raised civil liberties in public debate was during the Civil War and Reconstruction period. Northern abolitionists "worked hard to rally Northern opinion against the 'slave power conspiracy' by continually charging Southern leaders with following a deliberate program of repression of freedom of speech and of the press."2 Following the war, Southerners continued to face civil liberty restrictions under martial law. The Enforcement Act of 1870 and the Ku Klux Klan Act of 1871 legislated that the federal government could restrain that particular white interest group in order to protect the liberties of other American citizens, in this case African Americans. While the Ku Klux Klan and Enforcement Acts raised these issues, the failure of the Klan to stay intact diffused their threats to civil liberties. ${ }^{3}$

In 1873, the United States Congress passed the Comstock Act, which prohibited "obscene" material from being sent through the United States Postal System. ${ }^{4}$ With no clear definition of "obscene," the judiciary had to interpret and decide what was deemed to be obscene for the American people and the United States Postal Service. In turn, the judicial branch stipulated that contraception fell into the category of obscenity. When Dr.

\footnotetext{
${ }^{2}$ Paul L. Murphy, World War I and the Origin of Civil Liberties in the United States (New York: W.W. Norton and Company, 1979), 51-56.

3 For more information on issues of free speech during the Civil War years see Michael Kent Curtis, Free Speech, "The People's Darling Privilege (Durham: Duke University Press, 2000). In this book, Curtis argues that struggles for the freedom of speech over the course of the nineteenth century went beyond the First Amendment. Indeed, Curtis contended freedom of speech debates formed the core of democratic government. As people argued over what the freedom of speech meant, Americans gained a clearer understanding of their constitutional rights in general.

${ }^{4}$ David M. Rabban, Free Speech in Its Forgotten Years (New York: Cambridge University Press, 1997), 24.
} 
Edward Foote wrote a medical piece that included information for women on contraception, the federal courts convicted him of breaking the law. Following the case, Foote spent the remainder of this life defending the freedom of speech. ${ }^{5}$ Beside Foote and other medical specialists, many who identified themselves as free lovers opposed the restrictions of the Comstock Act. However, these groups remained isolated, keeping their causes separate and therefore, limiting their power against the majority of Americans who observed and respected the Comstock law.

In the late nineteenth century, working class groups protested in the 1886 Haymarket agitation and the 1894 Pullman Strike against the limitations of organizing and publicizing their working conditions. ${ }^{6}$ The Industrial Workers of the World (IWW) advocated on behalf of working class Americans. Legal scholar David Rabban explained, "Various forms of direct action, the IWW believed, would ultimately lead to a general strike, which would paralyze industry and bring about the abolition of capitalism." " Unhappy with the working conditions of American laborers, the IWW promoted strikes and demonstrations. Oftentimes, these forms of direct action led police to arrest IWW members for "obstructing the sidewalk, blocking traffic, vagrancy, unlawful assembly, or violating a local ordinance against street speaking." ${ }^{\prime 8}$ Most of the convicted IWW members pleaded not guilty on the grounds of their First Amendment rights. Yet, these events did not gather full public interest because of the negative stigma of the IWW organization as a proponent of anarchy. While Americans were aware of the IWW free speech fights, most Americans did not support the IWW's call for the end to

\footnotetext{
${ }^{5}$ Ibid.

${ }^{6}$ Ibid., 35.

${ }^{7}$ Rabban, 81 .

${ }^{8}$ Ibid.
} 
capitalism and constitutional government. Therefore, the workers' movement did not incite the force of the civil liberty movement of the twentieth century.

It was not until Congress enacted the wartime policies of World War I that a rarified, elite group of lawyers, legislators, and civil liberties interest groups started to understand and become concerned about how the United States government managed civil liberties.

In 1919, the Supreme Court decided on two key freedom of speech cases, Schenck v. United States and Abrams v. United States. Federal judges convicted the defendants in both cases of violating the Sedition and Alien Acts that President Woodrow Wilson and his administration created to curb dissent during the war years. Both defendants appealed their convictions to the United States Supreme Court on the basis that the Alien and Sedition Acts violated their freedom of speech protected under the First Amendment. With no precedent jurisprudence on the Alien and Sedition Acts of World War I, the Supreme Court had to sift its way through the evidence. It is necessary to examine how the Supreme Court ruled on both of these cases in order to appreciate how, in the course of one year, Associate Justices Louis Brandeis and Oliver Wendell Holmes Jr. revised and solidified their understanding of the freedom of political speech. This shift in Brandeis and Holmes's judicial opinions from the Schenck case to the Abrams case laid the foundation for Brandeis's significant role in shaping the jurisprudence of free political speech in the United States.

The Facts, Issues, and Decision of Schenck vs. United States 
On September 17, 1917, the judge of the Eastern District Court of Pennsylvania convicted Charles Schenck of crimes under the Espionage Act of June 15, 1917. According to the court record, in August 1917, the Pennsylvania police obtained a warrant from the judge of the Eastern District Court of Pennsylvania to search the Socialist Party headquarters where Schenck worked as its General Secretary. Police found that Schenck's secretarial books identified an order of 15,000 leaflets to be printed and mailed out to "men who had passed exemption boards, and for distribution." Schenck not only placed the order for the leaflets but he also worked on addressing envelopes and sending the leaflets out through the mail. In addition, police found a receipt for 125 dollars to be given to Schenck for the printing project. Because of the plethora of evidence identifying Schenck as a key figure in the printing project, no issue over his involvement existed; both sides stipulated to the facts in the case. However, the argument of the case lie in what the leaflet stated. Schenck was not arrested for printing and distributing a leaflet, but the police arrested him for printing and distributing a leaflet that police deemed to incite anti-war action.

Prosecution argued, "While the United States was at war, defendants circulated leaflets that urged men to refuse to submit to the draft into military service." Therefore, the prosecution determined, "for attempting to obstruct military recruitment, defendants were convicted of crimes pursuant to the Espionage Act, 40 Stat. 217, 219." ${ }^{10}$ In the Eastern District Court of Pennsylvania, the judge convicted the defendants. In response, Charles Schenck's lawyers, Henry Nelson and Henry Gibbons, appealed to the Supreme

${ }^{9}$ Schenck v. United States, 249 U.S. 47 (1919).

${ }^{10}$ Ibid., 1. 
Court of the United States, contending that "the distribution of the leaflets was activity protected by the First Amendment."11

Americans in the World War I period saw the rise of the American Civil Liberties Union under Roger Baldwin. The ACLU was "born out of the fight to defend free speech during World War I."12 Just as the Supreme Court struggled with Wilson's wartime policies, the ACLU made the fight for the First Amendment their guiding cause. As Samuel Walker explained:

Vocal opposition to the war sprang up immediately after Congress declared war on April 6. Indeed, it was the second most unpopular war in American history, rivaled only by the Vietnam War. Its critics were diverse: Socialists, religious pacifists, German-Americans and Irish-Americans, recent Eastern European immigrants, and isolationists. ${ }^{13}$

Several members from these groups organized together in order to strengthen their argument. Crystal Eastman and Roger Baldwin were two of the most outspoken and they banded together in the National Civil Liberties Bureau to fight against Congress's 1917 conscription measure. By 1918 they realized they needed to be fighting against much bigger issues than just the draft. Following the passage of the Espionage and Sedition Acts, Eastman and Baldwin shifted their focus to larger issues of the rights of speech, press, and assembly. However, as identified Socialists, members of the Civil Liberties Bureau faced a great deal of criticism from Wilson's administration. Nonetheless, the Civil Liberties Bureau continued to publicize their opinions through leaflets and memos. By 1919, Baldwin increased the membership of the Civil Liberties Bureau and developed such a following to create the American Civil Liberties Union. The writings

\footnotetext{
${ }^{11}$ Ibid.

${ }^{12}$ Walker, 3.

${ }^{13}$ Ibid., 12-13.
} 
of Zechariah Chafee influenced strongly the ACLU members and inspired them to rally behind Chafee's beliefs on the freedom of speech. In the cases of Schenck, Debs, and Abrams, the ACLU organized mass meetings to build up public support behind the defendants, but Baldwin soon gave up because "auditorium managers were reluctant to rent to him, and many of the prominent liberals he tried to recruit backed away."14 Nonetheless, the ACLU continued to help the cause by providing the funding and attorneys for other civil liberties cases. Walker explained, "By the fall of 1917 the NCLB's cooperating attorneys were handling about 125 conscientious objector cases a week." 15 Though rarely successful in their cases and oftentimes criticized by the media, the ACLU played a large role in planting the seed of civil liberties that developed into the rights consciousness of modern society.

On January 9 and 10, 1919, Schenck's lawyers, Henry Nelson and Henry Gibbons, who had ties to the ACLU, argued his case in front of the Supreme Court, a year and a half after Schenck's arrest and two months after the conclusion of World War I. Appealing a case to the Supreme Court was a tedious and expensive process. Only a handful of cases from World War I made it to the Supreme Court level because of these circumstances. Of the handful, Schenck was one. The case was important because it raised such issues as the First Amendment, freedom of speech, freedom of press, conspiracy, socialism, mail service, enlistment service, constitutional rights, and Congressional policy. Furthermore, it was one of the first cases to come out of World War I on the basis of the Espionage Act of 1917. By appealing the case to the Supreme

\footnotetext{
${ }_{15}^{14}$ Ibid., 23.

${ }^{15}$ Ibid., 24.
} 
Court, it allowed more lawyers, judges, and legislators to become aware of the significant issues it raised.

On March 3, 1919, the Supreme Court affirmed the judgments of the District Court of the United States for the Eastern District of Pennsylvania and upheld Charles Schenck's jail sentence. The vote was unanimous. Justices serving on the United States Supreme Court at that time were Chief Justice Edward White, Associate Justice Joseph McKenna, Associate Justice Oliver Wendell Holmes, Jr., Associate Justice William Day, Associate Justice Willis Van Devanter, Associate Justice Mahlon Pitney, Associate Justice James McReynolds, Associate Justice Louis Brandeis, and Associate Justice John Clarke. Associate Justice Oliver Wendell Holmes, Jr. wrote the unanimous opinion for Court.

Holmes's opinion began by stating that the Supreme Court found the defendant guilty of all three counts in his indictment. Holmes wrote that Schenck conspired against the Espionage Act of 1917 by "causing and attempting to cause insubordination in the military and naval forces of the United States, and to obstruct the recruiting and enlistment service of the United States, when the United States was at war with the German Empire." ${ }^{\prime 6}$ Secondly, the Court found Schenck to be guilty of conspiring to use the mail service to transmit materials that were deemed illegal by the standards of the Espionage Act. Third, the Court found Schenck to be guilty of using the mail service to transmit the unlawful materials. The sufficiency of evidence proved Schenck to be highly involved, if not leading the Socialist headquarters, in all of these illegal conspiracies.

${ }^{16}$ Ibid., 4. 
After confirming the guilt of Schenck's involvement, Holmes turned to the argument of the defense. In assessing the claim of the right to the First Amendment to print materials, in dicta Holmes declared that the privilege was limited when there was a "clear and present danger" in the speech or print. He explained that:

The question in every case is whether the words used are used in such circumstances and are of such a nature as to create a clear and present danger that they will bring about the substantive evils that Congress has a right to prevent. It is a question of proximity and degree. When a nation is at war many things that might be said in time of peace are such a hindrance to its effort that their utterance will not be endured so long as men fight and that no Court could regard them as protected by any constitutional right.

Holmes articulated that in times of war, the Supreme Court felt that freedom of political speech needed to be monitored more closely for the internal and external security of the country. Holmes faced difficulties in writing this opinion because the Supreme Court lacked precedent casework on the First Amendment. Furthermore, his judicial career demonstrated "little consideration for freedom of expression, as evidenced by his opinions in Cowley v. Pulsifer (1892), Hanson v. Globe Newspaper Company (1893), and Commonwealth $v$. Davis (1895)." 18 Therefore, Holmes crafted the Schenck opinion based on his personal experience and criminal law standards of evidence. Holmes applied the "question of proximity" criminal law standard to the Schenck case by doing a thorough analysis of the leaflet that Schenck and the Socialist Headquarters had distributed. Specific quotes that Holmes referred to in the leaflet included, "Assert Your Rights ... your right to assert your opposition to the draft .... If you do not assert and support your rights, you are helping to deny or disparage rights which it is the solemn duty of all

\footnotetext{
${ }^{17}$ Ibid., 5.

${ }^{18}$ Parker, Free Speech on Trial, 21.
} 
citizens and residents of the United States to retain."19 In the opinion of the Supreme Court, these statements not only expressed the opinion of the Socialists, but these statements called on American citizens to act directly. By sending the leaflets to drafted men, the Supreme Court could find no other intention for the flyer than calling on these men to refuse the draft and stay home in violation of the Sedition Act.

However, while Holmes emphasized that such a leaflet would not be ruled unconstitutional in peace times, he insisted:

The character of every act depends upon the circumstances in which it is done .... The most stringent protection of free speech would not protect a man in falsely shouting fire in a theatre and causing a panic. It does not even protect a man from an injunction against uttering words that may have all the effect of force. ${ }^{20}$

Thus, even out of wartime, Holmes deemed any speech that put others in danger was not protected under the First Amendment. Notice that Holmes did not say a "crowded" theatre; indeed, he believed that even if one person was endangered as a result of someone else's speech then the Court would rule it unconstitutional. The fact that his opinion went beyond war times to peacetime examples, such as someone shouting "fire" in a theater, set an important precedent for the Supreme Court in ruling on the freedom of speech in the following years and decades.

Once handed down, Holmes was unaware that his opinion would be so scrutinized. In fact, he hoped the Chief Justice would assign him the case, as he admitted to his friend Harold Laski that "[I] hoped the case would be assigned to [me], yet it 'wrapped itself around me like a snake in a deadly struggle to present the obviously proper in the forms of logic." Within two weeks of deciding Schenck, Holmes wrote

${ }^{19}$ Schenck, 4.

${ }^{20}$ Ibid., 4-5. 
again to Laski, admitting, "I greatly regret having to write them."21 Even for a powerful jurisprudential mind like Holmes, the crafting of jurisprudence for the First Amendment proved difficult because he and his brethren built on almost no precedent and jurisprudential heritage.

The Supreme Court applied the "clear and present danger" test to several cases following the Schenck case, including Frohwerk v. United States (1919) and Debs v. United States (1919). In Frohwerk, the Supreme Court upheld the conviction of Jacob Frohwerk for writing newspaper editorials that condemned American involvement in the war. In Debs, the Supreme Court upheld the conviction of Socialist Party's presidential candidate, Eugene Debs, for making an anti-war speech on a street corner in 1918. In hindsight, both Justice Holmes and Justice Brandeis vocalized regret in their initial rulings on freedom of speech cases coming out of World War I. In public, Holmes tended to cover up his discomfort with these initial rulings by repeatedly claiming, "I never have seen any reason to doubt that the questions of the law that alone were before this Court in the cases of Schenck, Frohwerk, and Debs ... were rightly decided." On the other hand, Brandeis was more forthcoming in taking responsibility for the Supreme Court's misunderstanding of the freedom of speech in these cases. In a letter to Harvard Law Professor Felix Frankfurter, Brandeis exclaimed, "I have never been quite happy about my concurrence in the Debs and Schenck cases. I had not then thought the issues of freedom of speech out. I thought at the subject, not through it." ${ }^{22}$ Fortunately the Abrams case argued later that year allowed Brandeis and Holmes a fresh opportunity, a

${ }^{21}$ Parker, Free Speech on Trial, 21.

22 Ibid., 26. 
second bite at the judicial apple, to reexamine the issue of the freedom of speech and the First Amendment even in wartime.

The Facts, Issues, and Decision of Abrams vs. United States

Nine months after the Supreme Court decided Schenck, a prosecution with the same defense of the right to the First Amendment arose to the Supreme Court in the case of Abrams vs. United States (1919). A large difference between the two cases was that Jacob Abrams, Mollie Steimer, Hyman Lachowsky, Samuel Lipman, and Jacob Schwartz were Russian immigrants in the United States whereas Charles Schenck was an American citizen. Abrams, Steimer, Lachowsky, Lipman, and Schwartz all immigrated to the United States between 1908 and 1913 to escape the anti-Semitic treatment of the Russian Czar's government. As young Russian and Jewish immigrants, they all found jobs in factories under working class conditions. ${ }^{23}$ Unsatisfied with their position in America, they began to read more to find out how to find better working conditions. Slowly they joined together with other frustrated workers and created an anarchist organization to fight against government regulations and poor working conditions of the working people. Their organization became politicized due to the Russian Revolution of 1917.

The start of World War I and the passage of the Espionage Act of 1917 and the Sedition Act of 1918 had a large impact on Abrams, Steimer, Lipman, Lachowsky, and Schwartz. When internal unrest erupted in Siberia in April 1918, President Wilson saw a need for intervention. In August 1918, he sent American troops to Russia to prevent another military conflict before it got out of hand and to intimidate Vladimir Lenin and

${ }^{23}$ Richard Polenberg, Fighting Faiths: The Abrams Case, the Supreme Court, and Free Speech (New York: Viking, 1987), 4-5. 
the Bolshevik Party. The start of the Bolshevik Revolution in Russia sent waves of fear through many Americans, including Wilson who feared that the Bolsheviks were "merely German pawns, and that military intervention would be a reasonable way of blocking German domination of Russia." 24 In response, such Russian immigrants as Abrams, Steimer, Lipman, Lachowsky, and Schwartz believed it was not America's place to intervene in a social revolution in Russia. These anarchists longed for political change in Russia. After all, the Czarist government had made them flee in the first place. With a desire to publicize their discontent with American intervention in the Russia Revolution, Abrams, Steimer, Lipman, Lachowsky, and Schwartz wrote and printed two leaflets. Samuel Lipman wrote one leaflet in English and Jacob Schwartz wrote a second leaflet in Yiddish. Then the leaflets were printed in mass volumes and distributed by Abrams, Steimer, Lipman, Lachowsky, and Schwartz from apartment windows and on street corners. $^{25}$

It was not long before police became aware of the pamphlets and concerned American citizens called for an investigation of the authors. After a difficult search, the police arrested the anarchists and took them to federal court. The federal government tried them in the District Court of the United States for the Southern District of New York where the Court found them guilty and denied bail. Harry Weinberger, attorney for the defendants, appealed this ruling on the basis of the First Amendment freedom of speech and press. The case reached the Supreme Court on October 21 and 22, 1919. The defendants were charged with:

${ }^{24}$ Ibid., 37.

${ }^{25}$ Ibid., 49-51. 
Conspiring, when the United States was at war with Germany, to publish disloyal language about the form of government of the United States, which was intended to bring the form of the government into contempt. to incite resistance to the United States in the war, to advocate curtailment of production of ammunition essential to the war. ${ }^{26}$

The prosecution, represented by Assistant Attorney General Stewart, blamed the defendants with violating the Sedition Act of 1918 in these crimes. After having decided Schenck just a few months before, the Supreme Court went into this case with the judicial doctrine of the "clear and present danger test" laid out in Holmes's unanimous opinion. Abrams raised a variety of issues including, revolution, conspiracy, freedom of speech and press, denouncement of government, anarchy, non-United States citizenship, and the distribution of circulars.

On November 10,1919 the Supreme Court decided by a vote of 7-2 to affirm the defendants' convictions. Associate Justice John H. Clark wrote the majority opinion declaring that sufficient evidence found the defendants to be guilty on four counts. On the first count, the Supreme Court found the defendants guilty of speaking in contempt of the United States Government. In the second count, Clark and the majority held that the leaflets contained language that gave the United States a disreputable name. In the third count, the majority of the Supreme Court found that the language used provoked people to act out against the United States. In the fourth count, Clark and the majority found that the defendants conspired to disrupt the war efforts of the United States.

The Supreme Court took into account the fact that all five defendants were Russian natives and had not applied for United States citizenship in their five to ten years in America. Clark stated this about the defendants in the majority opinion, "They were

${ }^{26}$ Abrams v. United States, 250 U.S. 616 (1919). 
intelligent, had considerable schooling, and at the time they were arrested they had lived in the United States terms varying from five to ten years, but none of them had applied for naturalization. ${ }^{27}$ This raised suspicions among the majority of the Court about the true intentions of the defendants in choosing to live and work in the United States. In addition, Clark explained:

Four of them testified as witnesses in their own behalf and of these, three frankly avowed that they were "rebels," "revolutionists," "anarchists," that they did not believe in government in any form, and they declare that they had no interest whatever in the Government of the United States. The fourth defendant testified that he was a "socialist" and believed in "a proper kind of government, not capitalistic," but in his classification the Government of the United States was "capitalistic." $" 28$

These self-characterizations declared by the defendants proved to the majority of the Supreme Court that the defendants held ill will for the United States government and that their circulars stemmed from their anti-government sentiments.

From there, Clark refuted the defendants argument for their freedom of speech by citing the case of Schenck vs. United States, Baer vs. United States (1919), and Frohwerk vs. United States (1919) to demonstrate that the defendants use of freedom of speech was a "clear and present danger" to the rest of the American community. ${ }^{29}$ He drew upon specific references in the leaflets to demonstrate the "clear and present danger." $\mathrm{He}$ quoted several citations in the leaflets pertaining to President Wilson's character including:

He [the President] is too much of a coward to come out openly and say: 'We capitalistic nations cannot afford to have a proletarian republic in Russia.' The Russian Revolution cries: Workers of the World! Awake! Rise! Put down your

${ }^{27}$ Ibid., 3.

${ }^{28}$ Ibid.

${ }^{29}$ Ibid., 4; Baer vs. United States, 249 U.S. 47 (1919); and Frohwerk vs. United States, 249 U.S. 204 (1919). 
enemy and mine! Yes! Friends, there is only one enemy of the workers of the world and that is CAPITALISM. ${ }^{30}$

Clark emphasized that such language urged working class citizens in the United States to rise up against the United States government. Clark argued that language that evoked this kind of direct action was a threat to Homeland Security and would not be tolerated. He went on to further point out examples of the leaflets inciting readers to take action by quoting, "Do not let the Government scare you with their wild punishment in prison, hanging and shooting. We must not and will not betray the splendid fighters of Russia. Worker, up to fight." 31 Clark and the majority of the Supreme Court maintained that these examples along with a number of other quotes from the leaflets demonstrated strong evidential proof that the defendants posed a "clear and present danger" to the United States.

Furthermore, Clark pointed to quotes from the pamphlets that pertained to America's involvement in the war. Clark and the majority of the Supreme Court found that following lines proved that the Russian defendants sought to interfere with the United States war with Germany:

With the money which you have loaned, or are going to loan them, they will make bullets not only for the Germans, but also for the Workers Soviets of Russia. Workers in the ammunition factories, you are producing bullets, bayonets, cannon, to murder not only the Germans, but also your dearest, best, who are in Russia and are fighting for freedom. ${ }^{32}$

Clark maintained that if ammunition factory workers were to quit producing ammunition, the United States soldiers on the frontlines with Germany would suffer because of a lack of supplies. Thus, while the Russians claimed that their priority was protecting the

\footnotetext{
${ }^{30}$ Abrams, 4.

${ }^{31}$ Ibid., 5.

${ }^{32}$ Ibid., 5.
} 
Russian Revolution from United States involvement, Clark argued that the defendants' messages went beyond that and posed a clear threat to the United States war effort against Germany. Besides a general strike that could cut off supply lines to United States troops in Europe, Clark also contended that:

The plain purpose of their propaganda was to excite, at the supreme crisis of the war, disaffection, sedition, riots, and, as they hoped, revolution, in this country for the purpose of embarrassing and if possible defeating the military plans of the Government in Europe. ${ }^{33}$

Undoubtedly, the majority of the Supreme Court found the true intent of the Russian defendants to go beyond their claim of merely supporting their Russian comrades in the Bolshevik Revolution. Clark and six other justices found sufficient evidence in the pamphlets to demonstrate that the defendants encouraged "resistance to the United States in the war. ${ }^{34}$

Associate Justice Oliver Wendell Holmes, Jr., who had written the unanimous opinion in the Schenck case in the spring of 1919 , in the fall of 1919 wrote the minority opinion in the Abrams case. With the support of Associate Justice Louis Brandeis, these justices in minority claimed, "the United States constitutionally may punish speech that produces or is intended to produce a clear and imminent danger that it will bring about forthwith certain substantive evils that the United States constitutionally may seek to prevent. ${ }^{, 35}$ In crafting such a rule, Holmes refined his previous opinion of Schenck. Holmes modified the "clear and present danger" standard rule into the "imminent threat" standard rule. He and Brandeis argued that while the leaflets of the defendants called for the derailing of the United States government, they did not see how "anyone can find the

\footnotetext{
${ }^{33}$ Ibid., 6 .

${ }^{34}$ Ibid.

${ }^{35}$ Ibid., 7.
} 
intent required by the statute in any of the defendants words. ${ }^{" 36}$ He referred to the postscript on the first leaflet that contended that the Russian authors were not trying to support the Germans. The postscript read, "It is absurd to call us pro-German. We hate and despise German militarism more than do you hypocritical tyrants. We have more reasons for denouncing German militarism than has the coward of the White House."”77 Holmes and Brandeis pointed out that the postscript constituted clear evidence that the defendants were not trying to interfere with the United States war with Germany. The defendants only sought to raise awareness of the situation in Russian. Holmes maintained:

The second leaflet is the only one that affords even a foundation for the charge, and there, without invoking the hatred of German militarism expressed in the former one, it is evident from the beginning to the end that the only object of the paper is to help Russia and stop American intervention there against the popular government-not to impede the United States in the war that it was carrying on.

Examining the same phrases as Clark, Holmes and Brandeis found a lack of evidence proving that the Russian defendants intended to hinder the American efforts against Germany. Indeed, Holmes and Brandeis argued that the only purpose for the pamphlets was to keep American troops out of the Russian Revolution. Holmes contended that those who believed the defendants to be guilty were misconstruing their words and objectives.

In his conclusion, Holmes declared in now famous civil liberties language:

When men have realized that time has upset many fighting faiths, they may come to believe even more than they believe the very foundations of their own conduct that the ultimate good desired is better reached by free trade in the ideas - that the best test of truth is the power of the thought to get itself accepted in the competition of the market, and that truth is the only ground upon which their

${ }^{36}$ Ibid., 8 .

37 Ibid., 7. 
wishes safely can be carried out. That at any rate is the theory of our Constitution .... While that experiment is part of our system I think that we should be eternally vigilant against attempts to check the expression of opinions that we loath and believe to be fraught with death, unless they so imminently threaten immediate interference with the lawful and pressing purposes of the law that an immediate check is required to save the country. ${ }^{38}$

In this conclusion, Brandeis and Holmes argued that the convictions of the defendants ought to be overturned because they did not interfere with the war cause nor did they violate the Sedition Act. Holmes warned that by convicting the defendants, the United States denied the freedom of expression that was essential to bringing new ideas to the nation. In this dramatic conclusion, Holmes emphasized the values that the United States was founded upon in the late eighteenth century. Holmes feared the effects of the Supreme Court limiting the freedom of speech. He warned that continuous checks on the freedom of expression would ultimately lead to the destruction of the United States because the Constitution would no longer protect the rights of the people.

In this minority opinion, Holmes wrote and Brandeis concurred with a new rule to the "clear and present danger" precedent. Indeed, Holmes and Brandeis's proposed "imminent threat" standard rule proved to have long lasting effects on the jurisprudence of the freedom of speech.

An Analysis of Holmes and Brandeis and Their Shifting Stance on Freedom of Speech in 1919

Following the Abrams decision, Holmes upheld his former decisions in cases such as Schenck vs. United States and Debs vs. United States (1919) because he claimed that those cases proved defendants were inciting a "clear and imminent danger" to the United

${ }^{38}$ Ibid., 8 . 
States' war with Germany. ${ }^{39}$ However, in the Abrams case Holmes made it clear that he had taken the time to reflect on the issue of the First Amendment, and he had shifted from his initial judgment in Schenck. ${ }^{40}$ As Stanford University legal historian Lawrence Friedman argued about Holmes's shift after the Schenck case, "Holmes did some soulsearching, and in the next free-speech case, Abrams v. United States, Holmes changed his mind somewhat; in this case he wrote a strong dissent. ${ }^{41}$ Following the Schenck decision, Holmes read many critiques of his judicial opinion, including the work of Zechariah Chafee. In response to Holmes's example of someone shouting "fire" in a theatre and causing a panic, Chafee exclaimed, "How about the man who gets up in a theater between the acts and informs the audience honestly but perhaps mistakenly that the fire exits are too few or locked? He is a much closer parallel to Schenck or Debs. ${ }^{.42}$ During the summer between Schenck and Abrams, Holmes read Zechariah Chafee's book, Freedom of Speech in War Time, in which Chafee claimed, "In the Espionage Act cases, Holmes had missed a 'magnificent opportunity' to indicate where to draw the line. ${ }^{43}$ Holmes invited Chafee for tea to discuss free speech. In turn, it was clear that Holmes had begun to reconsider his original position on the issue and that those who had critiqued his opinions in Schenck and Debs influenced him. His minority opinion in

\footnotetext{
${ }^{39}$ Debs v. United States, 249 U.S. 211 (1919).

${ }^{40}$ During the nine months between the two cases, documentation of Holmes's personal correspondences with Judge Learned Hand and Harold Laski, demonstrated his lingering uncertainty in his initial opinion; Parker, Free Speech on Trial, 21.

${ }^{41}$ Lawrence M. Friedman, American Law in the $20^{\text {th }}$ Century (New Haven: Yale University Press, 2002), 142.

${ }^{42}$ Parker, Free Speech on Trial, 24.

${ }^{43}$ Zechariah Chafee, Freedom of Speech in War Time (Cambridge, MA: Dunster House Bookshop, 1919).
} 
Abrams reflected his reconsideration of the First Amendment. To support this shift in his opinion, he drew on what he interpreted to be the true meaning of the Constitution.

In the same way, Louis Brandeis spent the nine months between the Schenck and Abrams cases doing what he did best, reviewing the evidence and examining the constitutional right of freedom of speech through a Progressive lens. In response to Holmes's dissenting opinion, Brandeis stated, "I join you heartily \& gratefully. This is fine-very." ${ }^{44}$ Upon learning that the conviction would be upheld, Abrams and the other Russian immigrants in the case attempted to flee the country. In time, the federal government and New York state police rounded them back up and imprisoned them. In a statement to the press, Hyman Lachowshky exclaimed:

Mr. Justice Holmes and Mr. Justice Brandeis have said that I had as much right to give out these leaflets as the United States has to issue its own Constitution. When my country, Soviet Russia, takes her equal place among the Nations of the world, recognized by all the Nations of the world, Russia will demand my freedom. I am willing to be that sacrifice in the hope that by it, the true libertyloving heart of America will awaken from its deadly sleep caused by the Espionage Law under which I was convicted. ${ }^{45}$

Indeed, the Abrams case did awaken the legal community of the United States, especially Justice Brandeis who moved forward from the case with a reformed approach to ruling on the freedom of speech. Yet, while the Abrams case allowed Brandeis to think through the freedom of speech more methodically it would not be until 1920 that Brandeis wrote his own judicial opinion on the matter. Up to that point, Holmes had taken the lead in writing the judicial opinions on Schenck and Abrams; consequently, Brandeis did not have the opportunity to express his own analysis of the freedom of speech. In 1923, Brandeis sent Felix Frankfurter a letter about the Supreme Court rulings on the Schenck,

\footnotetext{
${ }^{44}$ Polenberg, 236.

${ }^{45}$ Ibid., 246.
} 
Frohwert, and Debs. In this letter Brandeis explained, "Of course you must also remember that when Holmes writes, he doesn't give a fellow a chance- he shoots so quickly." 46 Thus, while Brandeis concurred with Holmes in judicial opinions on freedom of speech cases in 1919, he sought to explain himself on the matter. In 1920, he had the chance to do so.

\section{Conclusion}

Close analysis of the Schenck and Abrams cases provides historians insight into the American political and social realm of World War I. Public opinion favored Wilson's stand on espionage and sedition and from the small history of civil liberties prior to World War I it is evident why. American people wanted domestic security and a victory abroad; therefore, the American people accepted Wilson's wartime policies. President Wilson's administration identified the socialist background of Charles Schenck and the anarchist and foreign-born backgrounds of Abrams, Steimer, Lipman, Lachowsky, and Schwartz as internal threats to the country. Even before the federal government accused these men and women, the United States government monitored them for suspicious behavior. With the Espionage Act of 1917 and the Sedition Act of 1918, the Supreme Court had a difficult task in applying the new standards to the First Amendment. The Supreme Court had a tricky time determining whether a person was using their freedom of speech or causing a threat to internal security during wartime. Examining Brandeis and Holmes's shifting judicial opinions in 1919 demonstrates the difficulty of ruling on the constitutionality of restricting the First Amendment.

${ }^{46}$ Ibid., 266. 
By dissenting on the Abrams case, Holmes and Brandeis played key roles in shaping the eventual jurisprudence of the freedom of political speech. Though they represented the minority in 1919 , their dissenting argument that the "clear and present danger" test needed to be modified to the higher standard of the "imminent threat" test ultimately became the majority opinion of the Supreme Court in the 1969 case of Brandenburg v. Ohio. ${ }^{47}$ Fifty years prior to the ruling on Brandenburg, Brandeis and Holmes laid the foundation for the jurisprudence of the freedom of speech that most Americans find commonplace in the current era. In 2012, Historian Mark Tushnet wrote in a law review that referenced the Abrams dissent of Holmes and Brandeis. Tushnet argued,

Like all risks, the First Amendment risk varies along several dimensions, of which I will focus on three ... Risks can vary in magnitude as well: an anonymous pamphlet by a puny anonymity, to adopt on of Justice Holmes's phrases (Abrams v. United States, 250 U.S. 616, 629 (1919) (Holmes, J., dissenting)), increases the risk of law-breaking by a small amount; a speech by a person with great oratorical skills might increase the risk more. The circumstances under which words are uttered may affect the magnitude of the risk they impose. ${ }^{48}$

This statement provides a clear example of how the language and concepts used by Brandeis and Holmes to define the freedom of speech nearly a century ago maintain relevance and importance to the modern day. Still, Brandeis's role in the dissenting Abrams opinion was just the start of his work in reforming the judicial ruling on the

${ }^{47}$ Brandenburg vs. Ohio, 395 U.S. 444 (1969).

${ }^{48}$ Mark Tushnet, "The First Amendment and Political Risk," 4 Harvard Law Review 103 (Spring 2012). For further reading on recent law reviews that address the dissent of Brandeis and Holmes in the Abrams case please see Mark Strasser, "Mill, Holmes, Brandeis, and a True Threat to Brandenburg," 26 Brigham Young Law Review 37 (2011) and Vincent Blasi, "31 $1^{\text {st }}$ Annual Sullivan Lecture: Shouting "Fire!" in a Theatre and Vilifying Corn Dealers," 39 Capital University Law Review 535, (Summer 2011). 
freedom of speech. The following two chapters will trace the transformation of Brandeis into his firm stance on the civil liberty of speech. 


\section{CHAPTER IV}

\section{WRITING HIS OWN OPINION:}

BRANDEIS'S MINORITY DECISION IN GILBERT V. MINNESOTA

\section{The Facts and Issues of Gilbert v. Minnesota}

In 1920, a year following the Abrams decision, the United States Supreme Court decided another freedom of speech case that arose from the World War I era. This time, however, the defendant was not convicted of breaking the federal Sedition or Espionage Acts. On August 18, 1917, a state jury convicted Joseph Gilbert, manager of the Nonpartisan League, of violating a Minnesota statute that prohibited the obstructing or opposing of men enlisting in the United States military. The Minnesota statute read:

A statute of Minnesota makes it unlawful to interfere with or discourage the enlistment of men in the military or naval forces of the United States or of the State of Minnesota. It shall be unlawful for any person in any public place, or at any meeting where more than five persons are assemble, to advocate or teach by word of mouth or otherwise that men should not enlist in the military or naval forces of the United States or the state of Minnesota. It shall be unlawful for any person to teach or advocate by any written or printed matter whatsoever, or by oral speech, that the citizens of this state should not aid or assist the United States in prosecuting or carrying on war with the public enemies of the United States. Section 4 defines a citizen to be any person within the confines of the State, and declares violations of the act to be gross misdemeanors and punishable by fine and imprisonment. ${ }^{\text {' }}$

The Minnesota legislature enacted the statute on April 20,1917, prior to the federal Selective Service Act, enacted in May 1917, and the federal Espionage Act, enacted in

'Gen. St. Supp. 1917, 8521-2 to $8521-5$.

Gilbert v. State of Minnesota, 254 U.S. 325 (1920). 
June 1917. In August 1917, at a public meeting for the Non-partisan League in Minnesota, Gilbert delivered a speech that Minnesota officials found to discourage military conscription. In his speech Gilbert argued:

We are going over to Europe to make the world safe for democracy, but I tell you we had better make America safe for democracy first. You say, what is the matter with our democracy. I tell you what is the matter with it: Have you had anything to say as to who should be president? Have you had anything to say as to who should be Governor of this state? Have you had anything to say as to whether we would go into this war? You know you have not. If this is such a great democracy, for Heaven's sake why should we not vote on conscription of men. We were stampeded into this war by newspaper rot to pull England's chestnuts out of the fire for her. I tell you if they conscripted wealth like they have conscripted men, this war would not last over forty-eight hours. ${ }^{2}$

Due to the fact that the speech was made at a public meeting, Gilbert violated the statute for speaking out against enlistment in front of more than five people. Therefore, Minnesota police arrested Gilbert for crimes under the Minnesota statute and a jury at Minnesota district court level convicted him. The Goodhue county court sentenced Gilbert to one year in jail, a five hundred dollar fine, and prosecution costs. When Gilbert's attorneys, George Nordlin and Frederick Pike, appealed to the Minnesota State Supreme Court, the Minnesota Supreme Court upheld the judgment of the Goodhue jury and the constitutionality of the state statute.

In an expensive and tedious process that lasted three years, on November 10, 1920, Gilbert's lawyers managed to appeal Gilbert's conviction to the United States Supreme Court. The defense argued that Gilbert's conviction was wrong on two counts. They argued first that the Minnesota statute "usurped Congress's authority over the

\footnotetext{
${ }^{2}$ Ibid., 3 .
} 
military" and second, "that the statute violated the First Amendment."3 Gilbert's case raised the issues of military enlistment, state versus federal power, police power, free speech, pacifism, and clear and present danger. After oral arguments, the justices took over a month to debate issues and hand down their decision.

On December 13, 1920 the U.S. Supreme Court delivered its decision. In a vote of seven to two, the Supreme Court upheld the Minnesota Supreme Court decision. Justice Joseph McKenna and the majority of the Court found that:

First, the statute did not usurp congressional authority. The statute was a valid exercise of the State's police power because it was designed to promote patriotism amongst its citizens. Second, the statute did not violate the First Amendment. The Court pointed out that freedom of speech was not absolute, stating that it would have been a travesty on the constitutional privilege defendant invoked to assign him the protection of the First Amendment given the national circumstances at the time he made his speech. ${ }^{4}$

Justices concurring in the majority decision included Associate Justice Joseph McKenna, Associate Justice Oliver Wendell Holmes, Jr., Associate Justice William Day, Associate Justice Willis Van Devanter, Associate Justice Mahlon Pitney, Associate Justice James McReynolds, and Associate Justice John Clarke. Chief Justice Edward White and Associate Justice Louis Brandeis opposed Gilbert's conviction.

\section{Breaking Down the Majority Opinion}

Associate Justice McKenna wrote the opinion for the majority. He broke his opinion into two parts. First, he discussed the defendant's argument that the Minnesota statute overstepped the jurisdiction of the United States Congress and second, he

${ }^{3}$ Ibid., 1.

${ }^{4}$ Ibid. 
addressed the defendant's contention that the First Amendment protected him in speaking out during the war with Germany. To begin, McKenna listed the powers of the United States Congress, including, "provide for the common defense and general welfare of the United States, declare war, raise and support armies, make rules for the government and regulation of the land and naval forces." ${ }^{.5}$ Following these Congressional wartime privileges, McKenna explained that Gilbert's argument made it seem as though he was claiming to be a citizen of the United States, but not a citizen of Minnesota and therefore, Gilbert felt that he did not have to follow the legislation of the state. Furthermore, Gilbert's contention made it seem as if the states had no relation to the federal United States and McKenna clarified both of these points. He wrote,

Undoubtedly, the United States can declare war and it, not the States, has the power to raise and maintain armies. But there are other considerations. The United States is composed of the States, the States are constituted of the citizens of the United States, who also are citizens of the States, and it is from these citizens that armies are raised and wars waged, and whether to victory and its benefits, or to defeat and its calamities, the States as well as the United States are intimately concerned. And whether to victory or defeat depends upon their morale, the spirit and determination that animates them-whether it is repellent and adverse or eager and militant; and to maintain it eager and militant against attempts at is debasement in aid of the enemies of the United States, is a service of patriotism; and from the contention that it encroaches upon or usurps any power of Congress, there is an instinctive and immediate revolt. Cold and technical reasoning in its minute consideration may indeed insist on a separation of the sovereignties and resistance in each to any cooperation from the other, but there is opposing demonstration in the fact that this country is one composed of many and must on occasions be animated as one and that the constituted and constituting sovereignties must have power of cooperation against the enemies of all. Of such instance, we think, is the statute of Minnesota and it goes no farther. ${ }^{6}$

A great deal exists in this paragraph to weigh and assess. McKenna made a clear point that although the federal and state governments of the United States had separate powers,

\footnotetext{
${ }^{5}$ Ibid., 3 .

${ }^{6}$ Ibid., 4.
} 
overall their services to the people living in the United States overlapped. For example, while the federal Congress had the power to recruit an army, the soldiers came from the individual states. And when it came to war, a victory or defeat for the United States meant a victory or defeat for each of the states making up the United States. Therefore, McKenna and the majority of the Supreme Court argued that the Minnesota state government created the statute in order to aid the overall United States war effort by evoking patriotism in its citizens. They believed that the statute not only served to encourage Minnesota citizens in the defeat of Germany, but also to encourage the entire United States in the defeat Germany. They did not find the Minnesota statute to overstep the bounds of the United States Congress. In fact, they found that the statute offered nationalistic support for the war that the United States Congress declared.

In addition, McKenna cited the 1918 state law precedent State v. Holm, in which the Minnesota Supreme Court found that:

The contention was rejected that the Espionage Law of June 15, 1917, abrogated or superseded the statute, the court declaring that the fact that the citizens of the State are also citizens of the United States and owe a duty to the Nation, does not absolve them from duty to the State nor preclude a State from enforcing such a duty.

Unlike the Schenck v. United States case, the United States Supreme Court had precedent to work from in Gilbert's case. Citing the State v. Holm decision reinforced the majority opinion of the Supreme Court that the Minnesota statute did not violate federal authority. Instead, they observed the statute to be within the jurisdiction of the Minnesota state government. The majority of the Supreme Court found that American citizens belonged

\footnotetext{
${ }^{7}$ State v. Holm, 139 Minnesota 267 (1918).
} 
both to the nation and their individual states and therefore, had to observe dual citizenship laid out in the Fourteenth Amendment. For the majority, federalism mattered. In conclusion, McKenna and the majority of the Supreme Court found the first argument of the defense to be baseless because they argued, "the State is not inhibited from making 'the national purposes its own purposes to the extent of exerting its police power to prevent its own citizens from obstructing the accomplishments of such purposes. $"{ }^{8}$ In this final statement, the majority of the Supreme Court held that all states had the authority to enforce "police powers to preserve the peace of the State." The Minnesota statute did not hinder the war effort. In fact, it helped to stifle speech that obstructed the United States war effort. As the prosecution contended, the Minnesota statute maintained public peace and the jury found that Gilbert disrupted that peace. Gilbert made a speech in a public setting in which audience members did not appreciate his remarks. According to McKenna the prosecution found that in response to Gilbert's speech, "there were protesting interruptions, also accusations and threats against him, disorder and intimations of violence." ${ }^{\prime 10}$ McKenna contended that Minnesota created the statute to handle such instances in which a person evoked violence in public. The majority of the Supreme Court confirmed that the Minnesota statute held the proper function of keeping people like Gilbert from disrupting the peace and causing violence that might lead to injury of others.

In response to the defense's second argument that the Minnesota statute violated the right of free speech, McKenna and the majority of the Supreme Court explained that:

${ }^{8}$ Gilbert, 4.

${ }^{9}$ Ibid.

${ }^{10}$ Ibid., 5 . 
The asserted freedom as guaranteed or secured either by the Constitution of the United States or by the constitution of the State, we pass immediately to the contention and for the purposes of this case may concede it, that is, concede that the asserted freedom is natural and inherent, but it is not absolute, it is subject to restriction and limitation. And this we have decided. In Schenck v. United States, 249 U.S. 47, 52, we distinguished times and occasions and said that "the most stringent protection of free speech would not protect a man in falsely shouting fire in a theatre and causing a panic ....11

By 1920, the Supreme Court had decided a number of free speech cases from the World War I period in which most of the justices applied the "clear and present danger" standard. They pointed to precedent cases, such as Schenck, Frohwerk, Debs, and Abrams to confirm that the freedom of speech had some limitations, including situations in which the person speaking put other Americans in danger or invoked other Americans to violence.

In the case of Gilbert, the Supreme Court found that his speech created a clear and present danger to the citizens of Minnesota and the United States. His speech intended to work people into a frenzy and oppose the United States war with Germany. McKenna stated,

Gilbert's speech had the purpose they denounce. The Nation was at war with Germany, armies were recruiting, and the speech was the discouragement of that-its purpose was necessarily the discouragement of that. It was not an advocacy of policies or a censure of actions that a citizen had the right to make. ${ }^{12}$

The majority of the Supreme Court found that since United States Congress declared war in defense of the American nation, words against the effort symbolized words against the good of the nation. They contended that Gilbert was an educated man who understood the reasoning behind the United States joining the war, but he chose to preach inaccurate

\footnotetext{
${ }^{11}$ Ibid.

${ }^{12}$ Ibid.
} 
statements in order to hinder the United States objective in war and cause agitation among American citizens. In result, McKenna exclaimed, "[Gilbert] could have no purpose other than that of which he was charged. It would be a travesty on the constitutional privilege he invokes to assign him its protection." ${ }^{13}$ The majority of the Court believed that Gilbert knew he was making false statements in order to persuade people not to help in the war effort even though it was being fought to protect the nation. The Court decided that such lies did not deserve to be protected under the First Amendment of the United States Constitution.

Of the defense's two arguments, McKenna focused the bulk of his opinion on the concern of the Minnesota statute usurping the powers of the United States Congress. He addressed the issue of free speech in three short paragraphs. He cited the precedent case law and deemed that the "clear and present danger" standard rule made Gilbert's argument a mute point. McKenna's opinion gives evidence to the fact that the freedom of speech jurisprudence was in its early stages. The majority of the justices did not think outside of box on the issue. They based their decisions on prior cases that raised the same issues of free speech during the war.

While the majority vote included seven justices, only six agreed with the reasons stated in McKenna's opinion. Following his opinion, Associate Justice Holmes stated that he agreed with upholding Gilbert's conviction, but did not agree with the interpretation by McKenna and the other five justices in the majority decision. Holmes disagreed in large part with the first section of McKenna's opinion on the fact that citizens had a duty to state and national government and were accountable to the laws in

${ }^{13}$ Ibid. 
both domains. Holmes believed that state's rights overpowered national rights in this case and therefore, did not concur to the entirety of McKenna's opinion. ${ }^{14}$

\section{Breaking Down the Minority Opinion}

Chief Justice Edward White dissented from the majority opinion because he believed that "the subject-matter is within the exclusive legislative power of Congress, when exerted, and that the action of Congress has occupied the whole field." ${ }^{915}$ White contended that the issue of obstructing enlistment fell under the jurisdiction of the federal United States Congress. He believed that the Espionage Act of 1918 took priority over any state statute, including the Minnesota statute that the jury convicted Gilbert of breaking. In contradiction to Holmes, White believed that national supremacy reigned in this case, not states' right. White made no reference to the freedom of speech argument in his brief dissent. His main objection to Gilbert's conviction was that the state of Minnesota should not have had the statute in the first place. He believed the United States Congress held exclusive jurisdiction for subjects regarding war and the enlistment of troops.

While also dissenting. Associate Justice Brandeis did not vote against Gilbert's conviction for the same reasons as Chief Justice White. Brandeis stated upfront, "[Gilbert] claimed seasonably thai the statute violated rights guaranteed to him by the

Federal Constitution. This claim has been denied: and, in my opinion, erroneously." "16 Brandeis explained that although the Minnesota statute was technically implemented

\footnotetext{
${ }^{14}$ Chafee, Free Speech in the United States, 290.

${ }^{15}$ Gilbert, 5.

${ }^{16}$ Ibid., 6.
} 
during the war, it was not limited to the war. It was to be maintained after the war as well. To this point, Brandeis contended, "Unlike the Federal Espionage Act of June 15, 1917, c. 30, 40 Stat. 217, 219, [the Minnesota statute] applies equally whether the United States is at peace or at war. It abridges freedom of speech and of the press, not in a particular emergency, in order to avert a clear and present danger, but under all circumstances." 17 In contrast to the majority opinion and White's dissenting opinion, Brandeis's minority opinion focused on the freedom of speech issue of the case from the start. By comparing the state statute to the Espionage Act, Brandeis demonstrated how the Schenck ruling of a "clear and present danger" standard could not be applied in this case. He continued stating that the Minnesota statute went beyond the scope of the Espionage Act by prohibiting Minnesota citizens from advocating for pacifism. Because Minnesota enacted the statute months before Congress passed the United States Selective Service Act, Brandeis argued, "The prohibition imposed by the Minnesota statute has no relation to existing needs or desires of the Government. It applies although recruiting is neither in process nor in contemplation. For the statute aims to prevent not acts but beliefs." ${ }^{18}$ He continued explaining that such a statute affected everyone from religious preachers to school professors to parents because it prohibited them from speaking their beliefs on the subject or advising young men whether or not to join the military. The statute prohibited those who had moral or religious convictions about pacifism from teaching their beliefs to others.

In 1920, the judiciary had not yet employed the policy of incorporation, meaning the federal Bill of Rights did not apply to the states at this time. In 1833, in the case of

\footnotetext{
${ }^{17}$ Ibid.

${ }^{18}$ Ibid.
} 
Barron v. Baltimore, the defense brought the issue of whether federal rights should be applied to the states before the Supreme Court. After both sides of the case made their arguments, the Supreme Court decided that the federal Bill of Rights only applied to federal action. ${ }^{19}$ This decision stood firm for almost a century before the Supreme Court reconsidered the idea of incorporation. In the Gilbert case, Justice Brandeis questioned

\section{Barron stating:}

That such a law [reference to the Minnesota statute] is inconsistent with the conceptions of liberty hitherto prevailing seems clear. But it is aid that the guaranty against abridging freedom of speech contained in the First Amendment of the Federal Constitution applies only to federal action; that the legislation here complained of is that of a State; that the validity of the statute has been sustained by its highest court as a police measure; that the matter is one of state concern; and that, consequently this court cannot interfere. But the matter is not one merely of state concern. The state law affects directly the functions of the Federal Government. It affects rights, privileges and immunities of one who is a citizen of the United States; and it deprives him of an important part of his liberty. These are rights which are guaranteed protection by the Federal Constitution; and they are invaded by the statute in question. ${ }^{20}$

Brandeis was clear in his conviction that the federal Bill of Rights applies to all American citizens all the time. He found the prosecution's argument that the state of Minnesota had a right to limit citizens' freedoms for the sake of maintaining peace faulty. Brandeis contended that state laws affected the functions of the federal government and therefore, the federal Constitution needed to be applied. He explained that the power of the United States Congress to declare war and make decisions on the enlistment of troops meant that only the United States Congress should be enacting laws regarding whether or not legislation was necessary in order to maintain national security in times of war. $\mathrm{He}$ contended:

${ }^{19}$ Barron v. Baltimore, 32 U.S. 243 (1833).

${ }^{20}$ Gilbert, 6 . 
Congress, which has power to raise an army and naval forces by conscription when public safety demands, may, to avert a clear and present danger, prohibit interference by persuasion with the process of either compulsory or voluntary enlistment. As an incident of its power to declare war it may, when the public safety demands, require from every citizen full support, and may, to avert a clear and present danger, prohibit interference by persuasion with the giving of such support. But Congress might conclude that the most effective Army or Navy would be one composed wholly of men who had enlisted with full appreciation of the limitations and obligations which the service imposes, and in the face of efforts to discourage their doing so. ${ }^{21}$

Brandeis believed that Congress held the sole power in deciding whether freedom of speech should be limited to avoid a clear and present danger in times of war. He argued that the Congress may decide that freedom of speech is necessary in order to recruit a military of soldiers that embrace their war duties, instead of forcing recruitment upon those that hold pacifist beliefs. Brandeis highlighted the key point that Minnesota enacted the statute months before the federal Espionage and Selective Service Acts, which led him to believe that Minnesota had overstepped the federal Congress's war powers.

Brandeis continued his minority opinion by explaining that because the federal Congress decided whether or not the United States went to war, it was a federal right of all Americans to speak their opinion on the matter. He felt that states did not have a say in whether United States citizens supported or rejected a federal policy. He clarified:

The right of a citizen of the United States to take part, for his own or the country's benefit, in the making of federal laws and in the conduct of the Government, necessarily includes the right to speak or write about them; to endeavor to make his own opinion concerning laws existing or contemplated prevail; and, to this end, to teach the truth as he sees it. Were this not so 'the right of the people peaceably to assemble for the purpose of petitioning Congress for a redress of grievances, or for any thing else connected with the powers or duties of the national government' would be a right totally without substance. ${ }^{22}$

${ }^{21}$ Ibid.

${ }^{22}$ Ibid., 7. 
Brandeis argued that because the federal government declared war and later enforced conscription, American citizens deserved their federal rights when discussing these federal matters. Brandeis found that the national government had supremacy over the state governments and therefore, the national government determined what police powers the states held. He maintained:

But the duty of preserving the state governments falls ultimately upon the Federal Government .... And the superior responsibility carries with it the superior right. The States act only under the express direction of Congress .... The fact that they may stimulate and encourage recruiting ... does not give them the power by police regulations or otherwise to exceed the authority expressly granted to them by the Federal Government. ${ }^{23}$

Therefore, Brandeis determined that the Minnesota statute violated the authority of the federal government. He found that at that time Minnesota passed the statute, the federal government had not yet instituted mandatory conscription. Therefore, American men were free to join or not join the United States military as they pleased. Due to this fact, Brandeis argued that the Minnesota statute was incompatible with the federal policy because at that time the federal government still allowed open talks about government decisions in the war against Germany.

Upon passage of the Espionage Act in June 1917, two months after Minnesota enacted its statute, Brandeis explained that the two laws conflicted. He stated:

The federal act did not prohibit the teaching of any doctrine; it prohibited only certain tangible obstructions to the conduct of the existing war with the German Empire committed with criminal intent. It was so understood and administered by the Department of Justice. Under the Minnesota law, teaching or advice that men should not enlist is made punishable although the jury should find (1) that the teaching or advocacy proved wholly futile and no obstruction resulted; (2) that there was no intent to obstruct; and the court taking judicial notice of facts, should rule (3) that,

${ }^{23}$ Ibid. 
when the words were written or spoken, the United States was at peace with all the world. $^{24}$

Brandeis found that the Minnesota statute withheld citizens' rights to discuss their beliefs about enlistment and the war, whereas the Espionage Act only prosecuted those who spoke words that caused actual detriment to the United States war effort. He argued that the degree of difference in these two policies was the difference between maintaining homeland security and depriving citizens of their constitutional rights. Therefore, he resolved that the federal act overruled the state act under the power of national supremacy. States did not have the right to enact statutes that fell under the exclusive power of the United States Congress.

In conclusion, Brandeis made one last argument about how the Minnesota statute violating the Fourteenth Amendment. He stated:

As the Minnesota statute is in my opinion invalid because it interferes with federal functions and with the right of a citizen of the United States to discuss them, I see no occasion to consider whether it violates also the Fourteenth Amendment. But I have difficulty in believing that the liberty guaranteed by the Constitution, which has been held to protect against state denial the right of an employer to discriminate against a workman because he is a member of a trade union, Coppage v. Kansas, 236 U.S. 1, the right of a business man to conduct a private employment agency, Adams v. Tanner, 244 U.S. 590, or to contract outside the state for insurance of his property, Allgeyer v. Louisiana, 165 U.S. 578, 589, although the legislature deems it inimical to the public welfare, does not include liberty to teach, either in the privacy of the home or publicly, the doctrine of pacifism; so long, at least, as Congress has not declared that the public safety demands its suppression. I cannot believe that the liberty guaranteed by the Fourteenth Amendment includes only liberty to acquire and to enjoy property. ${ }^{25}$

This final point in Brandeis's minority opinion set the stage for the case of Gitlow v. New York (1925), which the Supreme Court decided on five years later. By including the reference to the Fourteenth Amendment, Brandeis opened the jurisprudence of the First

\footnotetext{
24 Ibid., 8.

${ }^{25}$ Ibid.. 8-9.
} 
Amendment to the idea of incorporation. In the Gilbert decision, Brandeis held that the Minnesota statute violated Gilbert's freedom of speech protected under the First Amendment of the federal Constitution. He argued that the national government's authority over war and enlistment overrode the state's policies; but, furthermore, he argued that the Fourteenth Amendment applied the national freedom of speech to the states and therefore, entitled Gilbert to make his August 18, 1917 speech. Brandeis's appeal to the Fourteenth Amendment proved influential in the coming years as the Supreme Court considered the idea of the federal Bill of Rights being applied to the states. As Zechariah Chafee, Jr. explained in his 1941 reflection on the Gilbert case, Still more significant is the opinion of Justice Brandeis. It may be a dissenting opinion, but its importance remains, because this is the first time that any member of the Court in any kind of published opinion squarely maintained that freedom of speech is protected against state action by the United States Constitution. Not, of course, by the original document of 1787, but by the Fourteenth Amendment, ratified in $1868 \ldots$... Nobody then realized that Gilbert v. Minnesota was the first glimmer of the new day which was to dawn with Gitlow v. New York. At that time, the Gilbert case was only one more disappointment of the hopes that the Supreme Court would protect free speech against encroachment. ${ }^{26}$

Brandeis's appeal to incorporation in Gilbert became part of the majority opinion in Gitlow v. New York. While still not fully concurring with the rest of the Court in the Gitlow case, Brandeis's transformative ideas about free political speech started to show up in the language of the majority. As Associate Justice Edward Sanford wrote in his majority opinion on the Gitlow case, "For present purposes we may and do assume that freedom of speech and of the press - which are protected by the First Amendment from abridgment by Congress - are among the fundamental personal rights and 'liberties' protected by the due process clause of the Fourteenth Amendment from impairment by

${ }^{26}$ Chafee, 295-298. 
the States. ${ }^{27}$ Slowly, but surely, Brandeis affected the jurisprudence of the freedom of speech. His dissenting arguments in Abrams and Gilbert proved influential in future rulings on First Amendment cases.

\section{The Significance of the Ruling on Gilbert v. Minnesota}

The Gilbert case is important to this study because it offered the first opportunity for Brandeis to clarify his understanding of the freedom of speech. Unlike McKenna who wrote the majority opinion and broke it into two separate addresses on state versus federal authority and freedom of speech, Brandeis found that the two defense arguments intertwined. At its root, Brandeis contended that the freedom of speech trumped any state policy because all American citizens were guaranteed that liberty in the United States Constitution.

Prior to this case, Brandeis did not have the chance to express his sentiments on freedom of political speech because in Schenck he had not fully thought through the meaning of free political speech and following Abrams, he bowed to the opinion of Holmes who was a veteran of the Supreme Court. In Gilbert, Brandeis stood alone in his opinion. Even Holmes did not see eye to eye with Brandeis on the importance of protecting freedom of speech in this particular case. As Richard Polenberg explained, "Oliver Wendell Holmes told Brandeis that he had gone 'too far' in his Gilbert dissent, and added, 'I have marked McK.[enns's] Op.[inion] 'Concur in result on the record.",,28 This dispute is significant among the justices to note because while Brandeis broke from the majority with Holmes in Abrams, he pushed ahead in his thinking on the

${ }^{27}$ Gitlow v. New York, 268 U.S. 652 (1925), 9.

28 Polenberg, 271. 
jurisprudence of the First Amendment. It would be some time before the majority of the Supreme Court started to understand and concur with Brandeis's forward-thinking position in the importance and centrality of the freedom of expression in United States culture. In the meantime, Brandeis continued to lay the foundation for the modern conception of the First Amendment jurisprudence. In the final case of this study, Whitney v. California (1927), Brandeis concurred with the rest of the Supreme Court in upholding the defendant's conviction; however, his separate opinion demonstrated his distinct attitude toward the freedom of speech. 


\section{CHAPTER V \\ CONCURRING, YET STANDING APART: \\ BRANDEIS'S OPINION ON WHITNEY V. CALIFORNIA}

The Facts, Issues, and Background of Whitney v. California

On November 28 1919, California authorities arrested Anita Whitney for crimes under the California Criminal Syndicalism Act, enacted on April 30, 1919. Little did Whitney know that by 1925 , six long years later, her case would have risen to the United States Supreme Court. ${ }^{1}$ Whitney v. California is the final case in this study because it demonstrates the epitome of Associate Justice Brandeis's influence on the jurisprudence of free speech. ${ }^{2}$ In his judicial opinion, Brandeis expressed eloquently the scope of the First Amendment. From breaking away from the majority of the Supreme Court in Abrams, to standing alone in Gilbert, Brandeis solidified his understanding of free speech in a political democracy in the Whitney case.

Unlike the previous two cases, Anita Whitney's arrest and conviction took place in the post-World War I years. Yet, California legislators enacted the California Criminal Syndicalism Act as a direct result of the war. While 1917 marked the year that the United States entered the Great War, it also marked the year of the Russian Revolution and rise of the Bolshevik Socialist Party in Russia. Unhappy with the high casualty rates,

\footnotetext{
${ }^{1}$ Haig Bosmajian, Anita Whitney, Louis Brandeis, and the First Amendment (Madison: Fairleigh Dickinson University Press, 2010), 13.

${ }^{2}$ Whitney v. California, 274 U.S. 357 (1927).
} 
famine, and unemployment, Russian workers became frustrated with the war conditions in late 1916, early 1917. At the same time, the Bolshevik political party rose to power under the promise of feeding and employing working people. In March 1917, the Russian Revolution took place and Tsar Nicolas II abdicated his throne. Under the leadership of Vladimir Lenin, the Bolshevik Party overthrew the Provisional Russian government. To fulfill their promises, Lenin and the Bolsheviks pulled Russia out of the war in order to focus on resolving domestic problems. ${ }^{3}$ They preached a system of socialism in which all people would share the country's wealth and power. Though the idea of socialism had roots reaching back to Karl Marx and earlier scholars, the Russian Revolution sparked international awareness of and concern about socialism.

The Russian Revolution inspired many unsatisfied Americans who did not favor the existing Constitutional government and capitalistic economy. Anita Whitney was one such American. Following World War I, pockets of communist groups formed throughout the United States. Americans identified this phenomenon as the Red Scare. The majority of Americans, including state and federal government officials, feared a revolution similar to Russia's; therefore, individual state governments took it upon themselves to institute policies that made it illegal for citizens to join organizations that advocated for revolutionary activity. On April 30, 1919, California enacted its Criminal Syndicalism Act, which prohibited California citizens from joining or participating in organizations that encouraged an overthrow of the state or federal governments. ${ }^{4}$

\footnotetext{
${ }^{3}$ Albert M. Craig, et al., The Heritage of World Civilizations, $8^{\text {th }}$ edition (Upper Saddle River: Pearson Education, Inc., 2009).

${ }^{4}$ California Statutes 1919, c. 188, p. 281.
} 
In 1919, Whitney joined the Communist Labor Party of California. Born into a well-known political family, the California officials monitored Whitney's political activity. After attending a national conference held by the Communist Labor Party in California, state officials arrested her for participating in an organization that promoted radical revolutionary activity to overthrow the current government. A county court convicted Whitney of criminal syndicalism. However, Whitney's lawyer, Walter H. Pollak, appealed the case, arguing that the Criminal Syndicalism Act violated the Fourteenth Amendment of the United States Constitution. ${ }^{5}$ The District Court of Appeal of California upheld the conviction and, in turn, Whitney's attorney appealed to the California Supreme Court, which at first denied the appeal and then after a second request to hear the case agreed. The California Supreme Court upheld the conviction. In 1925, the case then made its way to the federal Supreme Court, but the Court rejected it claiming they lacked jurisdiction. In 1926, the federal Supreme Court reversed itself and allowed the case to be argued. At long last, in 1927, the final ruling on the case came down with the entire United States Supreme Court upholding the conviction. Whitney's case raised the issues of criminal syndicalism, free speech, assembly, communism, industrialization, worker unrest, capitalism, federal versus state legal jurisdiction, revolution, terrorism, and imminent threat. ${ }^{6}$

In the nine years following the end of World War I, the historical context had changed in the United States. The post-war years brought prosperity to the United States. Change also took place on the Supreme Court. From Abrams to Gilbert, the Supreme Court maintained the same nine members; however, by 1927, the Supreme Court had five

\footnotetext{
${ }_{6}^{5}$ Whitney, 5 .

${ }^{6}$ Ibid., 1.
} 
new justices. Republican President Warren Harding appointed Republican William Howard Taft in 1921, Republican George Sutherland in 1922, Democrat Pierce Butler in 1923, and Republican Edward Sanford in 1923. Republican President Calvin Coolidge appointed Republican Harlan Stone in 1925. ${ }^{7}$ These cultural and political changes unquestionably played a significant role in how the Supreme Court ruled on cases in the later 1920s.

Yet over time, Brandeis's philosophy on free speech hardened. The purpose of this chapter is to analyze the differences between the two concurring Supreme Court opinions in the Whitney case. On May 16,1927, the Supreme Court ruled nine to zero in favor of upholding Whitney's conviction. However, seven justices concurred with Associate Justice Sanford's opinion and only Associate Justice Holmes concurred with Brandeis's opinion. Understanding the differences between the two opinions makes Brandeis's opinion read almost like a dissenting opinion. Brandeis's opinion laid the groundwork for the jurisprudence of the freedom of speech that Americans came to consider the norm by the early twenty-first century.

\section{An Analysis of Sanford's Concurring Opinion}

The justices concurring with Associate Justice Sanford's opinion included, Chief Justice Taft, Associate Justice Van Devanter, Associate Justice McReynolds, Associate Justice Sutherland, Associate Justice Butler, and Associate Justice Stone. Justice Sanford

\footnotetext{
${ }^{7}$ Kermit L. Hall, ed., The Oxford Companion to the Supreme Court of the United States, $2^{\text {nd }}$ ed. (Oxford: Oxford University Press, 2005), 130-131, 880-881, 990-992, 979-982, 997-999.
} 
started his opinion with a review of the evidence and argument of Whitney's case. He explained:

By a criminal information filed in the Superior Court of Alameda County, California, the plaintiff in error was charged, in five counts, with violations of the Criminal Syndicalism Act of that State. Statutes, 1919, c. 188, p. 281. She was tried, convicted on the first count, and sentenced to imprisonment. The judgment was affirmed by the District Court of Appeal. 57 Cal. App. 449. Her petition to have the case heard by the Supreme Court was denied. $I b .453$. And the case was brought here on writ of error which was allowed by the Presiding Justice of the Court of Appeal, the highest court of the State in which a decision could be had. Jud. Code, \$237. On the first hearing in this Court, the writ of error was dismissed for want of jurisdiction. 269 U.S. 530. Thereafter, a petition for rehearsing was granted, $I b .538$; and the case was again heard and reargued both as to the jurisdiction as the merits. ${ }^{8}$

Sanford included this summary in order to show the original conviction handed down by the California county court and then to demonstrate how the case had proceeded through the Appeal courts, both at the state and national level. He followed this summary with an address of the California Criminal Syndicalism Act to identify the provisions that related to Anita Whitney's involvement and actions within the Communist Labor Party. Sanford deemed two sections of the Act applicable to Whitney's conviction:

Section 1. The term 'criminal syndicalism' as used in this act is hereby defined as any doctrine or precept advocating, teaching or aiding and abetting the commission of crime, sabotage (which word is hereby defined as meaning willful and malicious physical damage or injury to physical property), or unlawful acts of force and violence or unlawful methods of terrorism as a means of accomplishing a change in industrial ownership or control, or effecting any political change. Section 2. Any person who: . . 4. Organizes or assists in organizing, or is or knowingly becomes a member of, any organization, society, group or assemblage of persons organized or assembled to advocate, teach or aid and abet criminal syndicalism ... is guilty of a felony and punishable by imprisonment. ${ }^{9}$

\footnotetext{
${ }^{8}$ Whitney, 5-6.

${ }^{9}$ Ibid., 6.
} 
The first section defined what criminal syndicalism entailed in the state of California. The Act specified that one who encouraged or supported violent methods to obtain political change was guilty of criminal syndicalism. The second section deemed it a crime for a person to become a member of an organization that encouraged or supported violent methods for obtaining political change.

Following his address of the Criminal Syndicalism Act, Sanford explained the importance of writ of error. He reinforced that according to division of powers in a federal system the United States Supreme Court was not to rule on state cases that did not raise a federal question. Sanford pointed out that Whitney's lawyer, Walter Pollak, had not raised a federal question originally. Sanford stated:

Here the record does not show that the defendant raised or that the State court considered or decided any Federal question whatever, excepting as appears in an order made and entered by the Court of Appeal after it had decided the case and the writ of error had issued and been returned to this Court. ${ }^{10}$

Thus, by law, the Supreme Court denied Whitney's 1925 appeal when her lawyer first applied to the federal Court. However, with the addition of questions of the federal question, the Supreme Court heard the case the second time around. In the 1926 arguments, Walter Pollak contended that the California Criminal Syndicalism Act violated the Fourteenth Amendment of the United States Constitution. Pollak argued:

The question whether the California Criminal Syndicalism Act ... and its application in this case is repugnant to the provisions of the Fourteenth Amendment to the Constitution of the United States, providing that no state shall deprive any person of life, liberty, or property, without due process of law, and that all persons shall be accorded the equal protection of the laws, was considered and passed upon by this Court. ${ }^{11}$

${ }^{10}$ Ibid.

${ }^{11}$ Ibid. 
Sanford and the majority of the Supreme Court critiqued the fact that Whitney's lawyer did not raise this federal question earlier, but accepted the petition to the case. Sanford cited a number of precedents that lacked federal questions from the beginning, but were accepted by the United States Supreme Court. Nevertheless, Sanford made it clear that the Supreme Court did favor the late petition and only accepted the case because of the precedent cases. He clarified, "So - while the unusual course here taken to show that federal questions were raised and decided below is not to be commended - we shall give effect to the order of the Court of Appeals as would be done if the statement had been made in the opinion of that court when delivered." ${ }^{12}$ The confusion surrounding whether Whitney's writ of error fit into the federal jurisdiction of the Supreme Court weighed heavily on the justices in their ultimate decision. Nonetheless, Sanford wrote that in 1926, the Supreme Court accepted Whitney's case, but limited their analysis to the question of the constitutionality of the California Criminal Syndicalism Act in regard to the Fourteenth Amendment. They did not extend the scope of the case beyond this question because the justices already had enough doubt about whether the federal question was posed in the appeal process in the first place.

After detailing the background information about how Anita Whitney's case reached the Supreme Court, Sanford dove into the evidence of the case. First he explained that undisputed evidence showed that Anita Whitney belonged to the local branch of the Socialist Party in Alameda County, California. When the national Socialist Party of America split between "radicals" and "old-wing Socialists," the Alameda branch

${ }^{12}$ Ibid. 
sided with the radical sect. ${ }^{13}$ In order to separate itself from the old-wing, the radicals renamed themselves the Communist Labor Party of America and created a new constitution. Sanford explained:

In its 'Platform and Program' the Party declared that it was in full harmony with 'the revolutionary working class parties of all countries' and adhered to the principles of Communism laid down in the Manifesto of the Third International at Moscow, and that its purpose was 'to create a unified revolutionary working class movement in America,' organizing the workers as a class, in a revolutionary class struggle to conquer the capitalistic state, for the overthrow of capitalist rule, the conquest of political power and the establishment of a working class government, the Dictatorship of the Proletariat, in place of the state machinery of the capitalist, which should make and enforce the laws, reorganize society on the basis of Communism and bring about the Communist Commonwealth - advocated, as the most important means of capturing state power, the action of the masses, proceeding from the shops and factories, the use of the political machinery of the capitalist state being only secondary; the organization of the workers into "revolutionary industrial unions"; propaganda pointing out their revolutionary nature and possibilities; and great industrial battles showing the value of the strike as a political weapon - commended the propaganda and example of the Industrial Workers of the World and their struggles and sacrifices in the class war .... ${ }^{14}$

In this long-winded sentence, Sanford detailed the mission statement of the newly formed Communist Labor Party that Whitney's local branch joined. The national organization adopted the policies of the Russian Communist Labor Party, which advocated for a working class revolution in America in order to overthrow the capitalist government in place. The Communist Labor Party made it no secret that they supported the use of revolutionary behavior. Sanford pointed out that Anita Whitney became active in the Communist Labor Party by serving as a delegate at the national convention in November, 1919. She worked on the Credentials and Resolutions Committees at the conference and she helped to draft a proposal for the Party's political action. Sanford explained that she played a large role in creating a proposal that recommended the following:

${ }^{13}$ Ibid., 7.

${ }^{14}$ Ibid. 
The C.L.P. of California fully recognizes the value of political action as a means of spreading communist propaganda .... The C.L.P. of California proclaims and insists that the capture of political power, locally or nationally by the revolutionary working class can be of tremendous assistance to the workers in their struggle for emancipation. Therefore, we again urge the workers who are possessed of the right of franchise to cast their votes for the party which represents their immediate and final interest - the C.L.P. ${ }^{15}$

Whitney's proposal promoted political change through the election process. It advocated for legal means of replacing the current government with Communist Labor Party members. In the defense argument, Whitney even claimed to have read this proposal in front of the convention, demonstrating her support of it. The Supreme Court accepted that she helped to design and promote the lawful proposal; however, Sanford explained that the National Convention of the Communist Labor Party rejected her plan and adopted the National Constitution of Moscow that promoted violence and terrorism to institute communist changes.

Sanford and the majority of the justices argued that while Whitney did not create or promote the newly adopted Constitution of the Communist Labor Party, her continued membership and involvement at the National Convention demonstrated her support of it. Sanford rejected Whitney's argument that "the character of the state organization could not be forecast when she attended the convention" because "[Whitney] not only remained in the convention, without protest, until its close, but subsequently manifested her acquiescence by attending as an alternate member of the State Executive Committee and continuing as a member of the Communist Labor Party." ${ }^{\prime 16}$ According to these facts, Sanford found the Alameda County Court and the California District Court of Appeals to

\footnotetext{
${ }^{15}$ Ibid.

${ }^{16}$ Ibid., 8 .
} 
be correct in their conviction of Whitney for being an active member of an organization that promoted political revolution, which violated the California Criminal Syndicalism Act. Sanford also noted that the defense's argument on the basis of this evidence did not involve a federal question and, therefore, did not fall within the jurisdiction of the Supreme Court. He rejected that this review of evidence had any relation to the question of constitutionality. ${ }^{17}$

In his second point, Sanford analyzed the defense's argument that the Criminal Syndicalism Act lacked clarity and meaning and therefore violated the Fourteenth Amendment's due process clause. Sanford contended that this argument was baseless because the California Criminal Syndicalism Act defined the term "criminal syndicalism." ${ }^{, 18}$ Sanford named several cases in which the question of due process did apply because of "vagueness and uncertainty" in the definition of state statutes, but he claimed that California Criminal Syndicalism Act did not come close to those precedent cases. ${ }^{19}$ Sanford stated:

The Act, plainly, meets the essential requirement of due process that a penal statute be "sufficiently explicit to inform those who are subject to it, what conduct on their part will render them liable to its penalties," and be couched in terms that are not "so vague that men of common intelligence must necessarily guess at its meaning and differ as to its application... This statute presents no greater uncertainty or difficulty, in application to necessarily varying facts, than has been repeatedly sanctioned by this court. Nash v. United States, 229 U.S. 373, 377; Miller v. Strahl, 239 U.S. 426, 434." So, as applied here, the Syndicalism Act required of the defendant no "prophetic" understanding of its meaning. ${ }^{20}$

\footnotetext{
${ }^{17}$ Ibid.

${ }^{18}$ Ibid.

${ }^{19}$ Ibid.

${ }^{20}$ Ibid., 8-9.
} 
Sanford found that the California legislature used sound, defining language in the construction of the Criminal Syndicalism Act to allow California citizens to understand its meaning. He even pointed out that the Supreme Court had ruled that Criminal Syndicalism acts from other states with less clear language had been deemed acceptable, so California's statute definitely did not violate the Fourteenth Amendment's due process clause in this argument.

Third, Sanford analyzed the defense's argument that the Syndicalism Act violated the equal protection clause of the Fourteenth Amendment based on:

The ground that, as [the Syndicalism Act's] penalties are confined to those who advocate a resort to violent and unlawful methods as a means of changing industrial and political conditions, it arbitrarily discriminates between such persons and those who may advocate a resort to these methods as a means of maintaining such conditions. ${ }^{21}$

The defense contended that the Communist Labor Party should be allowed to use violent means to promote their communist political beliefs just as they claimed the current capitalistic leaders of the United States used violence to maintain their power and policies. Sanford responded to this argument by stating:

It is settled by repeated decisions of this Court that the equal protection clause does not take from a State the power to classify in the adoption of police laws, but admits of the exercise of a wide scope of discretion, and avoids what is done only when it is without any reasonable basis and therefore is purely arbitrary; and that one who assails the classification must carry the burden of showing that it does not rest upon any reasonable basis to these methods as a means of maintaining such conditions. ${ }^{22}$

Sanford contended that the state legislatures had the power to create statutes aimed at prohibiting possible threats to the safety of its citizens. He said it would be impossible to

${ }^{21}$ Ibid., 9 .

${ }^{22}$ Ibid. 
think of every possible evil that could injure a citizen, but ihat state legislatures had to do their best to institute police powers that best protected their citizens. Furthermore, he argued that the California Criminal Syndicalism Act was not limited to the Communist Labor Party, he explained that "The Syndicalism Act is not class legislation; it affects all alike, no matter what their business associations or callings, who come within its terms and do the things prohibited. ${ }^{, 23}$ Sanford found that the Act applied to all California citizens, no matter their economic statues or job title, who violated its terms.

Furthermore, he legitimated the California Act on the basis that a number of other states had adopted similar Criminal Syndicalism Acts.

Finally, in his fourth point, Sanford addressed the defense's argument that the Syndicalism Act violated the due process of the Fourteenth Amendment in protecting a citizen's right to "speech, assembly, and association." ${ }^{24}$ Sanford found that in prior precedents, including Gitlow v. New York, the Supreme Court decided that:

The freedom of speech which is secured by the Constitution does not confer an absolute right to speak, without responsibility, whatever one may choose, or an unrestricted and unbridled license giving immunity for every possible use of language and preventing the punishment of those who abuse this freedom; and that a State in the exercise of its police power may punish those who abuse this freedom by utterances inimical to the public welfare, tending to incite to crime, disturb the public peace, or endanger the foundations of organized government and threaten its overthrow by unlawful means, is not open to question. ${ }^{25}$

According to precedent rule, Sanford and the majority of the Supreme Court found that they needed to observe the same standard in Whitney's case. Sanford contended that limits to the freedom of speech in cases existed where language incited violence or

\footnotetext{
${ }^{23}$ Ibid.

${ }^{24}$ Ibid.

${ }^{25}$ Ibid.
} 
danger to other citizens. He also emphasized that states had the right to limit free speech by police force when they felt the speech threatened the good of the state's citizens. In Whitney's case, the Court found her membership in an organization that advocated for criminal activity to secure their political objectives to provide substantial evidence that her freedom of speech needed to be limited for the safety of other California citizens.

In conclusion, Sanford and the majority of the Supreme Court found that the defense's arguments that the California Criminal Syndicalism Act violated the due process and equal protection clauses of the Fourteenth Amendment were unconvincing. Therefore, they ruled to uphold the conviction by the Court of Appeals. Sanford's opinion was direct and concise. He provided the background, evidence, and arguments of Whitney's case and then rejected the defense's line of reasoning in four succinct points. He applied precedent case law in all points made and confirmed the conviction of the State courts.

\section{An Analysis of Brandeis's Concurring Opinion}

While supporting Whitney's conviction, Associate Justice Brandeis did not agree with the reasoning given in Associate Justice Sanford's opinion. Brandeis upheld Anita Whitney's conviction because he believed her case did not fall within the jurisdiction of the Supreme Court. Indeed, he believed that Whitney's lawyers failed to raise a constitutional question from the beginning. Yet, outside of the question of jurisdiction, the rest of Brandeis's opinion read like a dissent. In an articulate manner in dicta, Brandeis expressed his deep beliefs about the scope of free political speech. His opinion in Whitney's case demonstrated how far he had come in his analysis of free speech from 
the time of Schenck v. United States in 1919. The following breakdown of Brandeis's opinion demonstrates how he approached Whitney's case and left behind a legacy of free political speech jurisprudence for the future.

Brandeis started his opinion with a summary of Whitney's arrest, conviction, and appeal. He stated:

Miss Whitney was convicted of the felony of assisting in organizing, in the year 1919, the Communist Labor Party of California, of being a member of it, and of assembling with it. These acts are held to constitute a crime, because the party was formed to teach criminal syndicalism. The statute which made these acts a crime restricted the right of free speech and of assembly theretofore existing. The claim is that the statute, as applied, denied to Miss Whitney the liberty guaranteed by the Fourteenth Amendment. ${ }^{26}$

Brandeis valued the facts and made sure to build his arguments on evidential proof. His language was direct and simple because he wanted readers to understand the reasoning behind his stance. Upon laying the evidence of the case out for readers, Brandeis demonstrated his discontent with the California Criminal Syndicalism Act. He argued:

The felony which the statute created is a crime very unlike the old felony of conspiracy or the old misdemeanor of unlawful assembly. The mere act of assisting in forming a society for teaching syndicalism, of becoming a member of it, or of assembling with others for that purpose is given the dynamic quality of crime. There is guilt although the society may not contemplate immediate promulgation of the doctrine. Thus the accused is to be punished, not for contempt, incitement or conspiracy, but for a step in preparation, which, if it threatens the public order at all, does so only remotely. The novelty in the prohibition introduced is that the statute aims, not a the practice of criminal syndicalism, nor even directly at the preaching of it, but at association with those who propose to preach it. ${ }^{27}$

Brandeis made it a point to show how the California Criminal Syndicalism Act broke from precedent laws because it did not convict people of teaching criminal syndicalism,

${ }^{26}$ Ibid., 10.
${ }^{27}$ Ibid. 
but it convicted those who even contemplated teaching criminal syndicalism. Brandeis found the California statute to be unconstitutional because it went outside the bounds of an imminent threat. Imminent threat rested at the heart of his opinion. Brandeis argued that the due process clause of the Fourteenth Amendment protected the fundamental rights of free speech and assembly, but yet he acknowledged that these rights were "not in their nature absolute. ${ }^{28}$ He explained:

Their exercise [referring to fundamental rights of free speech and assembly] is subject to restriction, if the particular restriction proposed is required in order to protect the State from destruction or from serious injury, political, economic or moral. That the necessity which is essential to a valid restriction does not exist unless speech would produce, or is intended to produce, a clear and imminent danger of some substantive evil which the State constitutionally may seek to prevent has been settled. ${ }^{29}$

Basing this case law on the "clear and present danger" standard of Schenck v. United States, Brandeis modified the ruling by changing the word "present" to "imminent." In doing so, he hoped to clarify the Schenck standard. He agreed that free speech and assembly needed to be limited when danger loomed in the face of these fundamental rights. The impending threat of violence or injury to other United States citizens overpowered a person's right to speak or assemble with others. However, he contended that when an imminent threat was not present, the First Amendment protected all Americans in their right to speak freely and assemble with others in a political democracy.

Following this line of reasoning, Brandeis made it clear that state legislatures had every right to enact legislation restricting organizations from preaching criminal syndicalism that "constitutes a clear and present danger of substantive evil;" yet, he

\footnotetext{
${ }^{28}$ Ibid.

${ }^{29}$ Ibid.
} 
stipulated that the state legislatures could only enact such legislation if they felt a strong possibility of imminent threat in their state. Brandeis found that the lack of clarity on this issue, both at the state and federal level, stemmed from the fact that the "clear and present danger" standard of Schenck v. United States was not defined. He wrote:

This Court has not yet fixed the standard by which to determine when a danger shall be deemed clear; how remote the danger may be and yet be deemed present; and what degree of evil shall be deemed sufficiently substantial to justify resort to abridgement of free speech and assembly as the means of protection. ${ }^{30}$

Brandeis found this to be a grave problem. Without defining the "clear and present danger" standard, justices had no definite grounds on which to convict those accused of overstepping their First Amendment rights.

To show his concerns about the jurisprudence of fundamental freedoms, Brandeis harkened back to the American Revolution and the Founding Fathers who created the American Constitution, in order to demonstrate the historical significance of protecting American freedoms. He eloquently wrote:

Those who won our independence believed that the final end of the State was to make men free to develop their faculties; and that in its government the deliberative forces should prevail over the arbitrary. They valued liberty both as an end and as a means. They believed liberty to be the secret of happiness and courage to be the secret of liberty. They believed that freedom to think as you will and speak as you think are means indispensable to the discovery and spread of political truth; that without free speech and assembly discussion would be futile; that with them, discussion affords ordinarily adequate protection against the dissemination of noxious doctrine; that the greatest menace to freedom is an inert people; that public discussion is a political duty; and that this should be a fundamental principle of the American government. ${ }^{31}$

In these powerful statements, Brandeis reminded readers of the fundamental values that underlay the United States. He argued that the Founding Fathers of the United States

${ }^{30}$ Ibid., 11.

31 Ibid. 
regarded free speech and assembly as the means by which citizens could make their opinions and concerns known. Without these freedoms, Americans would be deprived of the rights that made the American Revolution possible in the first place. He contended that free speech and assembly were part of being an active citizen. Most importantly, he noted that the American government was responsible for ensuring these liberties.

Brandeis provided support for his philosophy about the Founding Fathers by quoting Thomas Jefferson's first Inaugural Address in which Jefferson stated, "If there be any among us who would wish to dissolve this union or change its republican form, let them stand undisturbed as monuments of the safety with which error of opinion may be tolerated where reason is left free to combat it." ${ }^{32}$ Jefferson advocated for freedom of speech because he felt that debates allowed people to explain the reasoning behind their conflicting beliefs. Without free speech, people would not be able to comprehend or empathize with dissimilar viewpoints. Brandeis followed this reference by explaining that the Founders acknowledged the possible risks involved in free speech, but as Brandeis explained:

They knew that order cannot be secured merely through fear of punishment for its infraction; that it is hazardous to discourage thought, hope and imagination; that fear breeds repression; that repression breeds hate; that hate menaces stable government; that the path of safety lies in the opportunity to discuss freely supposed grievances and proposed remedies; and that the fitting remedy for evil counsels is good ones. Believing in the power of reason as applied through public discussion, they eschewed silence coerced by law - the argument of force in its worst form. Recognizing the occasional tyrannies of governing majorities, they amended the Constitution so that free speech and assembly should be guaranteed. ${ }^{33}$

\footnotetext{
${ }^{32}$ Ibid.

${ }^{33}$ Ibid.
} 
Brandeis included this reference to the Founders in order to address both state and federal legislation that limited the fundamental rights of American citizens. He argued that having statutes that threatened punishment for speaking about certain topics would cause people to fear speaking at all. In turn, he believed that stifled speech would cause resentment for state and federal governments and that the silence of American citizens would imply a tyrannical rule of all governments over its citizens. Later civil libertarians labeled this fear a "chilling effect" on political speech.

Brandeis contended that fear of danger or harm that might come of free speech was not enough for state and federal governments to limit the fundamental rights of free speech and assembly of American citizens. In his now famous quote, he stated, "Men feared witches and burnt women. It is the function of speech to free men from the bondage of irrational fears. ${ }^{34}$ Brandeis made the point that irrational fears, such as witches in the Middle Ages, resulted in the punishment and death of many innocent women who did not have the ability to defend themselves. Brandeis argued that free speech allows people to confront their fears and gain understanding of other peoples' perspectives. He explained that the only circumstance in which free speech should be limited is when a threat is clear and imminent. He stated, "To justify suppression of free speech there must be reasonable ground to fear that serious evil will result if free speech is practiced. There must be reasonable ground to believe that the danger apprehended is imminent." ${ }^{35}$ Seeking to define the "clear and present danger" of Schenck, Brandeis used the Whitney case as means of clarification on the suppression of free speech. He

\footnotetext{
34 Ibid.

35 Ibid.
} 
specified that the government only had the power to suppress speech if there was a

forthcoming threat to other American citizens. He wrote:

But even advocacy of violation, however, reprehensible morally, is not a justification for denying free speech where the advocacy falls short of incitement and there is nothing to indicate that the advocacy would be immediately acted on. The wide difference between advocacy and incitement, between preparation and attempt, between assembling and conspiracy, must be borne in mind. In order to support a finding of clear and present danger it must be shown either that immediate serious violence was to be expected or was advocated, or that the past conduct furnished reason to believe that such advocacy was then contemplated. ${ }^{36}$

Brandeis argued that a difference existed between protected free speech and speech that needed to be suppressed for advocating immediate injury to others.

Once again Brandeis used this opportunity to reflect back on the Founders of the United States. He stated:

Those who won our independence by revolution were not cowards. They did not fear political change. They did not exalt order at the cost of liberty ... Only an emergency can justify repression. Such must be the rule if authority is to be reconciled with freedom. Such in my opinion, is the command of the Constitution. It is therefore always open to Americans to challenge a law abridging free speech and assembly by showing that there was no emergency justifying it. ${ }^{37}$

According to the power of judicial review developed in Marbury v. Madison (1803),

Brandeis acknowledged that his role on the Supreme Court was to interpret the

Constitution according to how the framers intended it to be understood. He argued that if the Founders rallied behind the shift from a British monarchy to a republic, then they would oppose the stifling of conflicting political beliefs at any point in time. Quoting Zechariah Chafee, Brandeis stated, "You really believe in freedom of speech, if you are

\footnotetext{
36 Ibid.

${ }^{37}$ Ibid.
} 
willing to allow it to men whose opinions seem to you wrong or even dangerous. ${ }^{\text {38 }}$ Chafee's writings on freedom of speech influenced Associate Justices Brandeis and Holmes. Brandeis included the reference to Chafee in order to demonstrate that free speech opened the door to conflicting opinions and that was the beauty of protecting it in the United States.

Brandeis wrote that state and federal governments were only entitled to restrict free speech in cases of emergency. In cases when free speech or assembly created an emergency situation, the Constitution no longer protected a person's fundamental rights because he or she put others in danger. However, the degree of harm needed to be significant for government to step in. Brandeis contended that state police measures on free speech and assembly are unconstitutional if no serious threat can be identified. The possibility or chance that injury could ensue from free speech was not enough to justify suppression. A real and severe threat was necessary to uphold any state or federal law that restricted an American's right of free speech and assembly.

After spending the majority of his opinion defining the "clear and present danger" standard, in his last three paragraphs, Brandeis addressed the California Criminal Syndicalism Act. While dissenting from Sanford's opinion in his discussion of free speech, Brandeis explained why he concurred with upholding Whitney's conviction in these last three paragraphs of his opinion. He referred to section four of the Syndicalism Act to support his concurrence. Section four included the following statement:

Inasmuch as this act concerns and is necessary to the immediate preservation of the public peace and safety, for the reason that at the present time large numbers of persons are going from place to place in this state advocating, teaching and

38 Ibid. 
practicing criminal syndicalism, this act shall take effect upon approval by the Governor. $^{39}$

In his analysis of this statement, Brandeis found that it fit within the jurisdiction of California's state constitution, but not the federal United States Constitution. He wrote that California's state legislature had the power to enact such a statute in the case of emergency, in this case the considerable number of people promoting criminal syndicalism throughout the state. On the other hand, he argued that Whitney's lawyers failed to make the case relevant to the federal Constitution because they did not raise the questions pertaining to the federal constitutionality of Whitney's arrest and conviction from the beginning. He explained:

Whenever the fundamental rights of free speech and assembly are alleged to have been invaded, it must remain open to a defendant to present the issue whether there actually did exist at the time a clear danger; whether the danger, if any, was imminent; and whether the evil apprehended was one so substantial as to justify the stringent restriction interposed by the legislature. The legislative declaration, like the fact that the statute was passed and was sustained by the highest court of the State, creates merely a rebuttable presumption that these conditions have been satisfied. $^{40}$

Brandeis contended that it rested on the defense to raise the question of constitutionality regarding a person's speech. Building on the first half of his opinion, Brandeis said that it was the duty of the defendant to argue that their speech was not a clear and imminent threat to the public. In Whitney's case, he acknowledged that the defense made the argument that the California Criminal Syndicalism Act violated the federal Constitution; however, they did not provide evidence to show that Anita Whitney's speech and assembly lacked an imminent threat to other citizens. Therefore, while Brandeis

39 Ibid.

40 Ibid. 
advocated for the protection of free speech, he found a clear and imminent threat in

Whitney's speech and activity within the Communist Labor Party. He stated:

In the present case, however, there was other testimony which tended to establish the existence of a conspiracy, on the part of members of the International Workers of the World, to commit present serious crimes; and likewise to show that such a conspiracy would be furthered by the activity of the society of which Miss Whitney was a member. ${ }^{41}$

In conclusion, Brandeis found that the confusion over whether the Supreme Court had the authority to rule on Whitney's case plus the serious threat shown in the language of the organization that Whitney was a member of, proved that Whitney's conviction by the California state courts needed to be upheld. Associate Justice Holmes joined Brandeis in this concurring opinion.

\section{The Significance of Brandeis's Opinion in Whitney v. California}

After examining Sanford and Brandeis"s concurring opinions, it is clear that they held different reasons for upholding the California court's conviction. After throwing out the question of writ of error, Sanford focused his opinion on debunking the defense's argument that the California Criminal Syndicalism Act violated the due process and equal protection clauses of the Fourteenth Amendment. On the other hand, Brandeis used this opportunity to clarify the meaning behind the "clear and present danger" standard rule. Just as in his Gilbert opinion, Brandeis focused his attention on the question of free speech in Whitney's case.

While Brandeis decided to uphold the conviction because defense failed to provide a sound argument for the unconstitutionality of the California Act, his opinion

\footnotetext{
41 Ibid.
} 
left a legacy as one of the most notable defenses of free speech in a political democracy. By modifying the "clear and present danger" to a "clear and imminent" or "serious emergency" standard, he provided future Supreme Court justices with a better rule to guide their future decisions. Furthermore, his reflection on the Founders reached a large audience because it reminded United States citizens about the liberties that the United States built itself upon. His opinion broadened the scope of civil liberties consciousness and sparked new discussions about the meaning of free political speech among lawyers, scholars, and government officials.

From his dissent with Holmes in Abrams, to his individual dissent in Gilbert, Brandeis solidified his beliefs on free speech in the Whitney case. In fact, Brandeis had already written his opinion on free speech for Charles Ruthenberg's case in March 1927, but Ruthenberg died before the Supreme Court handed down its decision, so the case was thrown out. Therefore, Brandeis was waiting for a case like Whitney's in order to share his beliefs on the jurisprudence of free speech. Though disappointed that his opinion fell into a concurring vote, Brandeis used the Whitney case to publish his interpretations about what the framers really meant by freedom of expression in the First Amendment.

Historian Mark Tushnet reinforced the impact of Brandeis opinion in the Whitney case in his work, I Dissent: Great Opposing Opinions in Landmark Supreme Court Cases. Tushnet stated:

Some scholars view Justice Brandeis's opinion as the greatest "dissent" in the Supreme Court Reports. It is celebrated for two main reasons. First, it develops a legal doctrine identifying the scope of the protection the First Amendment affords expression, and that doctrine eventually became the law ... The second, and perhaps more important, reason for why Justice Brandeis's opinion endures is its powerful rhetoric. Justice Brandeis was rarely eloquent. He had made his reputation as a man of facts and details, not of words so powerful that they 
captured the imagination ... Justice Brandeis set out an account of democracy and self-government that cannot fail to move the reader. ${ }^{42}$

Brandeis's opinion not only provided language for future Supreme Court justices to draw upon in free speech cases, but also provided American citizens with a defense against limits on their political speech. By proving that their speech did not create an imminent threat, American citizens who held contradictory opinions about politics and society had a better form of protection from state and federal limitations on speech and assembly. Brandeis's opinion in Whitney v. California proved to be his most influential role in shaping the eventual jurisprudence of the freedom of speech in the United States.

42 Mark Tushnet, ed., I Dissent: Great Opposing Opinions in Landmark Supreme Court Cases (Boston: Beacon Press, 2008), 98-99. 


\section{CONCLUSION}

\section{BRANDEIS'S LEGACY ON FREE SPEECH}

Change defined the Progressive and World War I eras of the United States.

Social, cultural, industrial, political, intellectual, and legal reforms dominated the period. Many influential Americans led the progressive movement that culminated in World War

I. Louis D. Brandeis was one such progressive who played a vital role in the reformation of free speech at this time. However, just as the Progressive Era proved to have many complexities regarding who was involved and what issues they stood for, Brandeis was a complex progressive. While advocating for more government involvement in protecting workers from employers, Brandeis advocated for greater protections from big government in the free speech cases. Brandeis was not a straight-laced progressive. In

his various roles as a lawyer, reformer, Zionist leader, and jurist, Brandeis acted and ruled according to how he interpreted the evidence in each situation. Over his time on the Supreme Court, Brandeis educated himself on the meaning of free political speech and dramatically shifted his stance from Schenck to Whitney. There is no black and white understanding of Brandeis or his evolution in ruling on free speech. Nevertheless, Brandeis had a powerful effect on the United States during his lifetime; his lasting legacy shaped the jurisprudence of free political speech.

Brandeis's opinions in the Abrams, Gilbert, and Whitney decisions demonstrate the transformation and solidification of his convictions about how the framers intended the United States Constitution to protect political speech. It is important to understand 
the limited civil liberties consciousness in the United States leading into World War I. For this reason, the Supreme Court lacked precedent to base their decision-making upon free speech cases that arose out of the environment of World War I. Alongside Associate Justice Holmes, Brandeis contributed to forming and defining the language used to decide free speech cases. Brandeis sought to understand the substance of the First Amendment of the Constitution and in his findings he determined that the Founders of the United States valued the freedom of speech. As a result, Brandeis used the power of judicial review to uphold what he found to be the fundamental meaning of free speech under the 1787 United States Constitution and the 1791 federal Bill of Rights.

While each branch of the federal government plays a role in interpreting the Constitution, Supreme Court justices have the unique condition of life term in office. Although the justices are not immune from political allegiances, the life term allows for a certain degree of freedom in their decision-making. The question of how much power each federal branch has over constitutional interpretation is a topic for a different study. The significance here is that all Supreme Court opinions, both majority and minority, are saved and used as precedent for future cases. Despite the fact that Brandeis's opinions were not always part of the majority, the Supreme Court kept his writings on file and in later years used his arguments to overturn earlier decisions on free political speech. On the Supreme Court, Brandeis exercised law to create an environment for dissent and political dialogue.

Although Brandeis valued the right of free speech, he examined each case individually. While dissenting in Gilbert, Brandeis concurred with upholding the conviction in Whitney. He did not ignore the evidence of the case in order to fight his 
battle for the protection of free speech. He crafted his opinions to incorporate a running judicial discussion of the protection of free speech.

From 1919 to 1927, Brandeis helped to develop the scope of the First Amendment. The more cases that raised the question of free speech, the more Brandeis thought through the matter. A few months later, explaining the discrepancy between his judgment in Schenck versus his judgment in Abrams, Brandeis admitted that he had not fully thought through the meaning of protecting free speech under the First Amendment of the United States Constitution. Coming out of the historical context of World War I, the Supreme Court found Associate Justice Holmes's standard of the "clear and present" danger to satisfy the conviction of a Socialist Party leader printing pamphlets that opposed the war. However, both Holmes and Brandeis continued their research on free speech over the following summer and found that the "clear and present" standard lacked sufficient definition and, therefore, threatened the Founder's intent regarding political speech.

In Abrams, Holmes and Brandeis demonstrated their reformulated interpretations of the First Amendment, specifically the right of free speech. Writing the minority opinion, Holmes introduced the "imminent threat" standard. He and Brandeis argued that although the defendants spoke out against the American efforts in Russia, they did not incite an imminent threat to the American public. The Abrams case created the "imminent threat" standard, which Holmes and Brandeis solidified in the coming years. Their dissent in Abrams demonstrated how Holmes and Brandeis had taken time to reflect on the "clear and present" standard of free speech and rework the judicial rule for weighing speech rights against valid internal security concerns. They feared that the 
"clear and present" standard could be used to create unforeseen limitations of free speech by all levels of government and, therefore, they sought to clarify the meaning of the standard. It was significant that Holmes wrote the opinions in both of these cases because it showed that he wanted to amend the "clear and present" standard that he himself had created.

The question of Brandeis's personal orientation to the defendants in the Abrams case is a point of interest. Brandeis's parents emigrated from Eastern Europe and identified themselves as Jews, which related to the Russian Jewish backgrounds of the defendants in the case. Therefore, one might argue that this connection weighed on Brandeis's ruling in the case. And this may have been true. However, more research needs to be done on this question. In the present study, the fact that the other cases did not involve immigrants demonstrates that Brandeis did not rest his case completely on the Jewish immigrant backgrounds. in deciding whether or not the Constitution protected a person's free speech.

After 1920, Brandeis found himself alone in his mission to protect political speech. In the Gilbert case, Brandeis wrote a dissenting opinion that gathered no support from the other Supreme Court justices. In his opinion he argued that the "due process" clause of the Fourteenth Amendment applied the First Amendment, including the speech clause, to and against the states. Brandeis contended that free political speech was a fundamental right of citizens that the states did not have the power to limit through their state statutes. He found the fact that Minnesota enacted its statute prior to the United States Congress enacting the Selective Service Act and Espionage Act to be an issue of state versus federal power. He contended that the Minnesota government had 
overstepped the federal power of Congress to enforce laws regarding the war and war policy. In this argument, Brandeis defended national supremacy over state power. His argument demonstrated the beginnings of a shift from state to federal power over the course of the twentieth century. Brandeis's opinion raised the issue of "selective incorporation" to a limited audience of legal scholars and jurists, which, in turn, eventually led to the 1925 incorporation of the First Amendment in Gitlow v. New York. While most of Brandeis's legacy on the jurisprudence of free speech came after his death, the incorporation standard proved the significance of his work within his lifetime.

In the final case of this study, Whitney v. California (1927), Brandeis produced his most eloquent and powerful opinion. Building on Holmes's Abrams "imminent threat," Brandeis provided a full explanation of why the "clear and present" standard needed to be reworked and defined. Drawing on the power of judicial review, Brandeis included large passages referring to the Founding Fathers and what they meant by speech freedoms in the First Amendment. He argued that the United States was founded on political dissent from the tyrannical British rule and therefore, the Founders promoted open discussions in order to avoid the return of tyrannical government at any level. Brandeis explained that limits could only be placed on an American's freedom of political speech if his or her speech incited an imminent and serious evil that would cause injury to other American citizens. He clarified that even the possibility of a threat was not enough to stifle political speech because Americans had the fundamental right to express opposing and even dangerous ideas. Only imminent danger to others provided federal and state governments the power to step in and suppress a person's political speech. 
Brandeis concurred in the conviction of Anita Whitney because of the question of whether the case fell within the jurisdiction of the Supreme Court or not, and the fact that the Communist Labor Party did, in fact, incite an imminent threat to the American public. However, his defense of free speech created the argument and language that later Supreme Court justices used to overturn "clear and present danger" and adopt the "imminent threat" standard. Over forty years after Brandeis and Holmes handed down their opinion in Whitney, the Supreme Court instituted their modified standard in Brandenburg v. Ohio (1969). Although neither Holmes nor Brandeis lived to hear the Supreme Court decision for Brandenburg, they understood in their lifetime the importance of laying the foundation for free speech jurisprudence. Brandeis's earnest defense of free speech in the 1920s created the traction for the Supreme Court to start grappling with the Founding Fathers' true intent for the First Amendment. The Supreme Court decisions in Gitlow and Brandenburg drew upon Brandeis's language and line of reasoning. The legal standards of incorporation and imminent threat demonstrate that Brandeis played the key role in the shaping of the jurisprudence for the freedom of speech.

By including the opposing opinions in each of the cases examined in this study, it is possible to see both the limited attention to civil liberties consciousness and Brandeis's role in making free speech a topic of national concern. In all three cases, the justices who wrote the opposing opinions to Brandeis spent limited time addressing the freedom of speech. Following Schenck, the majority of justices referred to the "clear and present" precedent as the rule of the Court and went no further in their consideration of the scope of free speech. Brandeis did. He struggled to define the nature, rule, and substance of 
the freedom of speech and he argued for strict protection of what he considered to be a fundamental right of all American citizens. His persistent defense of the freedom of political speech widened the limited civil liberties consciousness in the United States.

Tangentially and although the civil rights movement did not take off until the 1950s and 1960s, Brandeis established the groundwork for the civil rights movement through his advocacy of free speech in the 1920s. The transformation of his thoughts on free speech over the course of the three cases discussed in this work demonstrated his increasing resolve about the importance of protecting the freedom of political speech of minorities in the United States. Americans living in the Progressive Era witnessed many reforms, but Brandeis's striving for the legal reform of the freedom of speech proved to be one of the most significant legacies of that time period. The dialogue he initiated about the breadth and limits of free political speech in his Supreme Court opinions has challenged every succeeding generation of Americans. 


\title{
REFERENCES
}

\author{
Articles
}

Blasi, Vincent. " $31^{\text {st }}$ Annual Sullivan Lecture: Shouting "Fire!" in a Theatre and Vilifying Corn Dealers." 39 Capital University Law Review 535 (Summer 2011).

Blasi, Vincent. "Propter honoris respectum: Reading Holmes through the lens of Schauer: The Abrams dissent." Notre Dame Law Review 72 (1997).

Bobertz, Bradley. "The Brandeis Gambit: The Making of America's 'First Freedom,' 1909-1931." William and Mary Law Review 40 (February, 1999).

Dow, D. R., \& Shieldes, R. S. "Rethinking the clear and present danger test." Indiana Law Journal 73 (1998).

Fish, S. "Fraught with death: Skepticism, progressivism, and the First Amendment." University of Colorado Law Review 64 (1993).

Gendzel, Glen. "What the Progressives Had in Common." The Journal of the Gilded Age and Progressive Era 10 (July 2011): 331-339.

Lahav, Pnina. "Holmes and Brandeis: Libertarian and Republican Justification for Free Speech." The Journal of Law and Politics 4 (Winter, 1988).

Lawrence, Thomas A. "Eclipse of Liberty: Civil Liberties in the United States during the First World War." Wayne Law Review 21 (1974): 33-112.

Novick, S. M. "Symposium: Oliver Wendell Holmes, Jr.: The judging years: Holmes's Constitutional jurisprudence." Southern Illinois University Law Journal 18 (1994).

O'Brian, John Lord. "Uncle Sam's Spy Policies: Safeguarding American Liberty during the War." The Forum 61 (April 1919): 407-416.

Skover, David, and Ronald Collins. "Curious Concurrence: Justice Brandeis' Vote in Whitney v. California." Supreme Court Review 2005 (2006).

Strasser, Mark. "Mill, Holmes, Brandeis, and a True Threat to Brandenburg." 26 Brigham Young Law Review 37 (2011). 
Tushnet, Mark. "The First Amendment and Political Risk." Harvard Law Review 10 (Spring 2012).

Weinberg, L. "Holmes's failure." Michigan Law Review 96 (1997).

White, E. G. "The First Amendment comes of age: The emergence of free speech in the twentieth-century America." Michigan Law Review 95 (1996).

Wigmore, J. H. "Abrams v. United States: Freedom of speech and freedom of thuggery in war-time and peace-time." Illinois Law Review 14 (1920).

\section{Books}

Baker, Leonard. Brandeis and Frankfurter: A Dual Biography. New York: Harper \& Row, 1984.

Baker, Ray Stannard and William E. Dodd. The New Democracy: Presidential Messages, Addresses, and Other Papers. New York: Harper, 1962.

Bickel, Alexander M. The Unpublished Opinions of Mr. Justice Brandeis: The Supreme Court at Work. Chicago: The University of Chicago Press, 1967.

Bosmajian, Haig. Anita Whitney, Louis Brandeis, and the First Amendment. Madison: Fairleigh Dickinson University Press, 2010.

Brickner, Paul. Review of Louis D. Brandeis: A Life. By Melvin Urofsky. Albany Government Law Review 507 (2011).

Capozzola, Christopher. Uncle Sam Wants You: World War I and the Making of the Modern American Citizen. New York: Oxford University Press, 2008.

Chafee, Jr., Zechariah. Free Speech in the United States. Cambridge, Mass.: Harvard University Press, 1941.

Chafee, Jr., Zechariah. Freedom of Speech in War Time. Cambridge, Mass.: Dunster House Bookshop, 1919.

Chatfield, Charles. For Peace and Justice, 1914-1941. Knoxville: University of Tennessee Press, 1971.

Cooper, John Milton Jr. The Warrior and the Priest: Woodrow Wilson and Theodore Roosevelt. Cambridge, Mass: The Belknap Press of Harvard University Press, 1983.

Cooper, John Milton. Woodrow Wilson: A Biography. New York: Alfred A. Knopf, 2009. 
Cortner, Richard C. The Supreme Court and Civil Liberties Policy. Palo Alto: Mayfield Publishing Company, 1975.

Craig, Albert M., et al. The Heritage of World Civilizations. $8^{\text {th }}$ edition. Upper Saddle River: Pearson Education, Inc., 2009.

Creel, George. How We Advertised America: The First Telling of the Amazing Story of the Committee on Public Information that Carried the Gospel of Americanism to Every Corner of the Globe. New York: Harper \& Brothers, 1920.

Curtis, Michael Kent. Free Speech, "The People's Darling Privilege. Durham: Duke University Press, 2000.

Dawson, Nelson Lloyd. Louis D. Brandeis, Felix Frankfurter, and the New Deal. Hamden: Archon Books, 1980.

De Haas, Jacob. Louis D. Brandeis: A Biographical Sketch. New York: Bloch Publishing Company, 1929.

Dirck, Brian. Waging War on Trial: A Handbook with Cases, Laws and Documents. Santa Barbara: ABC..CLIO, 2003.

Farber, Daniel. Security versus Liberty: Conflicts between Civil Liberties and National Security in American History. New York: Russell Sage Foundation, 2008.

Ferrell, Robert H. Woodrow Wilson and World War 1, 1917-1921. New York: Harper \& Row, Publishers, 1985.

Friedman, Lawrence. American Law in the $20^{\text {th }}$ Century. New Haven: Yale University Press, 2002.

Hall, Kermit L. and Peter Karsten. The Magic Mirror: Law in American History. $2^{\text {nd }}$ ed. New York: Oxford University Press, 2009.

Hall, Kermit L., ed. The Oxford Companion to the Supreme Court of the United States. $2^{\text {nd }}$ ed. Oxford: Oxford University Press, 2005.

Hays, Samuel P. Conservation and the Gospel of Efficiency: The Progressive Conservation Movement, 1890-1920. Cambridge, Mass.: Harvard University Press, 1959.

Hofstadter, Richard. The Age of Reform. New York: Vintage Books, 1955.

Johnson, Donald. The Challenge to American Freedom: World War I and the Rise of the American Civil Liberties Union. Lexington, Ky.: University of Kentucky Press, 1963. 
Kennedy, David M. Over Here: The First World War and American Society. New York: Oxford University Press, 1980.

Kloppenberg, James T. Uncertain Victory: Social Democracy and Progressivism in European and American Thought, 1870-1920. New York: Oxford University Press, 1986.

Kolko, Gabriel. The Triumph of Conservatism: A Reinterpretation of American History, 1900-1916. Chicago: Quadrangle Books, 1967.

Konefsky, Samuel J. The Legacy of Holmes and Brandeis: A Study in the Influence of Ideas. New York: Collier Books, 1956.

Lears, T.J. Jackson. No Place of Grace: Antimodernism and the Transformation of American Culture, 1880-1920. New York: Pantheon Books, 1981.

Lief, Alfred. Brandeis: The Personal History of an American Ideal. New York: Stackpole Sons, 1936.

Link, Arthur S. Woodrow Wilson and the Progressive Era, 1910-1917. New York: Harper \& Row Publishers, 1963.

Longakers, Richard P. The Presidency and Individual Liberties. Ithaca: Cornell University Press, 1961.

Lunardini, Christine. From Equal Suffrage to Equal Rights: Alice Paul and the National Woman's Party, 1910-1928. New York: toExcel Press, 1986.

Marchand, C. Roland. The American Peace Movement and Social Reform. Princeton: Princeton University Press, 1972.

Mason, Alpheus. Brandeis: A Free Man's Life. New York: The Viking Press, 1946.

McCloskey, Robert G. The American Supreme Court. Chicago: The University of Chicago Press, 2010.

McGerr, Michael. A Fierce Discontent: The Rise and Fall of the Progressive Movement in America, 1870-1920. New York: Free Press, 2003.

Mock, James R. and Cedric Larson. Words that Won the War. Princeton: Princeton University Press, 1939.

Murphy, Paul L. Liberty and Justice: A Historical Record of American Constitution Development. New York: Knopf, 1963. 
Murphy, Paul L. Meaning of Freedom of Speech; First Amendment Freedoms from Wilson to FDR. Westport: Greenwood Publishing Company, 1972.

Murphy, Paul L. World War I and the Origins of Civil Liberties in the United States. New York: W. W. Norton \& Company, 1979.

Paper, Lewis. Brandeis. Englewood Cliffs: Prentice-Hall, Inc., 1983.

Parker, Richard. Free Speech on Trial: Communication Perspectives on Landmark Supreme Court Decisions. Tuscaloosa: University of Alabama Press, 2003.

Peterson, H. C. Propaganda for War: The Campaign Against American Neutrality. Norman: University of Oklahoma Press, 1939.

Polenberg, Richard. Fighting Faiths: the Abrams case, the Supreme Court, and Free Speech. New York: Viking, 1987.

Preston, William. Aliens and Dissenters: Federal Suppression of Radicals, 1903-1933. Cambridge, Mass.: Harvard University Press, 1963.

Rabban, David M. Free Speech in Its Forgotten Years. New York: Cambridge University Press, 1997.

Read, James M. Atrocity Propaganda, 1914-1917. New Haven: Yale University Press, 1941.

Scheiber, Harry N. The Wilson Administration and Civil Liberties, 1917-1921. Ithaca: Cornell University Press, 1960.

Skocpol, Theda. Protecting Soldiers and Mothers: The Political Origins of Social Policy in the United States. Cambridge, Mass.: Harvard University Press, 1992.

Strum, Philippa. Brandeis: Beyond Progressivism. Lawrence: University Press of Kansas, 1993.

Strum, Philippa. Louis D. Brandeis: Justice for the People. Cambridge, MA: Harvard University Press, 1984.

Thomas, William H. Jr. Unsafe for Democracy: World War I and the U.S. Justice Department's Covert Campaign to Suppress Dissent. Madison: The University of Wisconsin Press, 2008.

Traxel, David. Crusader Nation: The United States in Peace and the Great War, 1898 1920. New York: Alfred A. Knopf, 2006.

Tushnet, Mark, ed. I Dissent: Great Opposing Opinions in Landmark Supreme Court 
Cases. Boston: Beacon Press, 2008.

Urofsky, Melvin I. Louis D. Brandeis: A Life. New York: Pantheon Books, 2009.

Walker, Samuel. In Defense of American Liberties: A History of the ACLU. Carbondale: Southern Illinois University Press, 1999.

White, G. Edward. The American Judicial Tradition: Profiles of Leading American Judges. $3^{\text {rd }}$ ed. Oxford: Oxford University Press, 2007.

Wiebe, Robert H. The Search for Order, 1877-1920. New York: Hill and Wang, 1967.

Vaughn, Stephen. Holding Fast the Inner Lines: Democracy, Nationalism, and the Committee on Public Information. Chapel Hill: University of North Carolina Press, 1980.

Case Law

Abrams et al. v. United States. 250 U.S. 616 (1919).

Baer v. United States. 249 U.S. 47 (1919).

Barron v. Baltimore. 32 U.S. 243 (1833).

Brandenburg v. Ohio. 395 U.S. 444 (1969).

Debs v. United States. 249 U.S. 211 (1919).

Frohwerk vs. United States. 249 U.S. 204 (1919).

Gilbert v. State of Minnesota. 254 U.S. 325 (1920).

Gitlow v. New York. 268 U.S. 652 (1925).

Marbury v. Madison. 5 U.S. 137 (1803).

Schenck v. United States. 249 U.S. 47 (1919).

State v. Holm. 139 Minnesota 267 (1918).

Whitney v. California. 274 U.S. 357 (1927).

\section{Manuscripts}

American Civil Liberties Union Records, The Roger Baldwin Years, 1917-1950. Princeton University Library. Department of Rare Books and Special Collections. 
Seeley G. Mudd Manuscript Library. Public Policy Papers. Princeton, NJ.

\section{Writings By Brandeis}

Brandeis, Louis. The Curse of Bigness: Miscellaneous Papers of Louis D. Brandeis. Edited by Osmond K. Fraenkel. New York: Viking Press, 1934.

Brandeis, Louis. The Family Letters of Louis D. Brandeis. Edited by Melvin I. Urofsky and David W. Levy. Norman: University of Oklahoma Press, 2002.

Brandeis, Louis. "Half Brother, Half Son": The Letters of Louis D. Brandeis to Felix Frankfurter. Edited by Melvin Urofsky and David Levy. Norman: University of Oklahoma Press, 1991.

Brandeis, Louis. Letters of Louis D. Brandeis: Volume IV (1916-1921): Mr. Justice Brandeis. Edited by Melvin Urofsky and David Levy. Albany: State University of New York Press, 1975.

Brandeis, Louis. Letters of Louis D. Brandeis: Volume V (1921-1941): Elder Statesman. Edited by Melvin Urofsky and David Levy. Albany: State University of New York Press, 1978.

Brandeis, Louis and Samuel Warren. "The Right to Privacy." Harvard Law Review 4 (1890).

\section{Statutes}

California Statutes 1919. c. 188. p. 281.

Espionage Act of 1917. Public Law 65-24. U.S. Statutes at Large 217 (1917).

Minnesota Gen. St. Supp. 8521-2 to 8521-5 (1917).

Sedition Act of 1918. Public Law 65-150. U.S. Statutes at Large 553 (1918). 


\section{CURRICULUM VITAE}

NAME: $\quad$ Elizabeth Diane Todd

ADDRESS: 3007 Kaye Lawn Drive

Louisville, KY 40220

DOB: $\quad$ Louisville, Kentucky - January 4, 1988

EDUCATION

\& TRAINING: $\quad$ B.A., History and French Literature and Language

Transylvania University

2006-2010

$\begin{array}{ll}\text { AWARDS: } & \text { Graduate Dean's Citation } \\ & \text { University of Louisville } \\ & 2013\end{array}$

Outstanding Graduate Student Award

History Department

University of Louisville

2013

Graduate Teaching Assistant

University of Louisville

2012-2013

Hamilton Scholarship

University of Louisville

2012-2013

Graduate Assistant

University of Louisville

2011-2012

James Madison Junior Fellow

James Madison Memorial Fellowship Foundation

2011 